$$
\text { UNIVERSIDADE DE SÃO PAULO }
$$

FACULDADE DE FILOSOFIA, LETRAS E CIÊNCIAS HUMANAS

DEPARTAMENTO DE LETRAS CLÁSSICAS E VERNÁCULAS

PROGRAMA DE PÓS-GRADUAÇÃO EM LITERATURA PORTUGUESA

MARIA CAROLINA VAZZOLER BISCAIA

\title{
"BELEZA, PERVERSIDADE, VÍCIO E DOENÇA" - UM PASSEIO PELA LITERATURA DO MAL DE MÁRIO DE SÁ-CARNEIRO
}


UNIVERSIDADE DE SÃO PAULO

FACULDADE DE FILOSOFIA, LETRAS E CIÊNCIAS HUMANAS

DEPARTAMENTO DE LETRAS CLÁSSICAS E VERNÁCULAS

PROGRAMA DE PÓS-GRADUAÇÃO EM LITERATURA PORTUGUESA

\section{"BELEZA, PERVERSIDADE, VÍCIO E DOENÇA" - UM PASSEIO PELA LITERATURA DO MAL DE MÁRIO DE SÁ-CARNEIRO}

Maria Carolina Vazzoler Biscaia

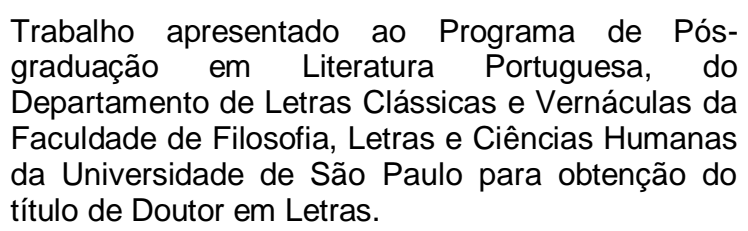

Orientadora: Prof. ${ }^{\text {a }}$ Dra. Raquel de Sousa Ribeiro

São Paulo

2012 
a Artur, Yolanda, Fláuia, Maria Olímpia e Claudia. 
Meus sinceras agradecimentas...

Aas meus pais Artur Gilda Biscaia e Yalanda Vazzaler Biscaia. à Fláuia Vazzaler Biscaia e Regina Angel Ganzález Radríguez. às familias Biscaia e Vazzaler. Aa Claudia Jasé das Santas.

Aa Leanarda Baptista Carreia, Márcia Radrigues Bia Araúja, Marta Lúcia Carrêa, Sérgia Raberta Silueira e, principalmente, a tadas de que eles descendem.

Aa Alexandre Fernandes de Almeida, Paula César Géglia e Tiaga Fernandes de Sauza.

Aa Edsan de Oliueira e Dumit Ablud.

à professara Dra. Maria Helena Nery Garcez è à Professara Dra. Aurara Gedra Ruiz Aluarez.

Aa professar Dr. Carlas Alkerta Véchi e à Praf. ${ }^{a}$ Dra. Maria Thereza Martinha Zambanim.

à minha querida arientadara Prof. 'Dra. Raquel de Sausa Rikeira par tadas as arientaçães e conversas francas. 


\section{RESUMO}

BISCAIA, M.C.V.. "Beleza, perversidade, vício e doença." - Um passeio pela literatura do mal de Mário de Sá-Carneiro. Tese (Doutorado). Faculdade de Filosofia, Letras e Ciências Humanas, Universidade de São Paulo, 2012.

Esta tese discorre sobre como a obra do escritor português Mário de SáCarneiro apresenta uma ligação com o mal, tomando como sustentação teórica as discussões propostas por George Bataille, Elizabeth Roudinesco e Martin Heidegger. A tese aponta como as personagens e os eu líricos optam pelo escapismo para outras realidades, para lugares míticos e para as múltiplas identidades, como forma de serem mais livres e de burlarem as regras morais que estão postas pela sociedade portuguesa da época. É por meio deste escapismo que se tem a possibilidade de criar uma vida envolta em mistério e repleta de momentos singulares. Com a ausência de uma moral que possa tolher o indivíduo de seus mais íntimos segredos é que a literatura de SáCarneiro envereda para a morte, o suicídio, o crime, o incesto, o homossexualismo e outros comportamentos que podem sugerir sua ligação com o mal. Com um universo deslocado do real, os textos têm como cena as noites parisienses, os refinados e sofisticados artistas e a crença de que a arte é sagrada e que, como tal, elege seus poucos representantes, e estes passam a ter seus caminhos ungidos por tal distinção. São as relações entre o escapismo, o mistério, a morte, as perversões e a arte que dão os subsídios para a inscrição da obra de Mário de Sá-Carneiro como um receptáculo daquilo a que chamamos de literatura do mal.

Palavras-chaves: Mário de Sá-Carneiro, mal, decadentismo, perversão, arte, literatura portuguesa. 


\section{ABSTRACT}

BISCAIA, M.C.V.. "Beauty, perversity, addiction and illness" - A promenade in Mário de Sá-Carneiro's literature of evil. Thesis (Doctoral). Faculty of Philosophy, Letters and Human Sciences, University of São Paulo, 2012.

This paper describes how Mário de Sá-Carneiro's works have a connection with evil. The theory is supported by George Bataille, Elizabeth Roudinesco and Martin Heidegger's proposed discussions. The thesis notes how characters and poetic personae choose escaping to other realities, mythical places and multiple personalities as means of setting free or bending the moral rules which the Portuguese society held during that period. This escapism enables a mysterious, particular lifestyle. By lacking morals that may curb people's most secret desires, Sá-Carneiro's literature trails towards death, suicide, crime, incest, homosexuality and other unrighteous behaviors. By detaching from reality, the texts portray Parisian nights and sophisticated artists. It was believed that art was sacred and for that reason few were chosen to represent it. As a result, artists were allegedly annointed for such a distinction. The relationship between escapism, mystery, death, perversions and art shapes Mário de SáCarneiro's work into what we call literature of evil.

Keywords: Mário de Sá-Carneiro, evil, decadence, perversiveness, art, portuguese literature. 


\section{SUMÁRIO}

INTRODUÇÃO .09

CAPÍTULO 1 - ESCAPISMOS: UMA VEREDA PARA O MAL......................18

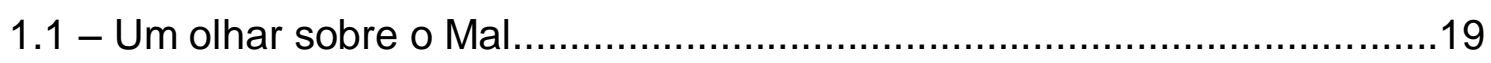

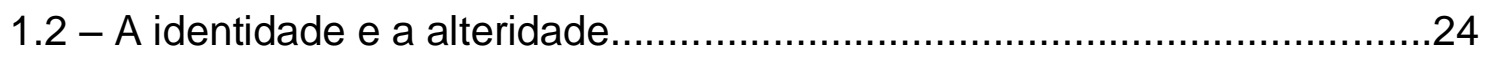

1.3 - As muitas formas de representação do real.............................................

1.4 - Do desalento pelo espaço português a outros espaços ..........................42

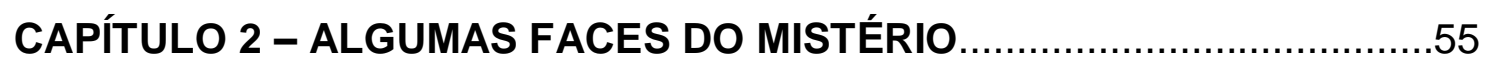

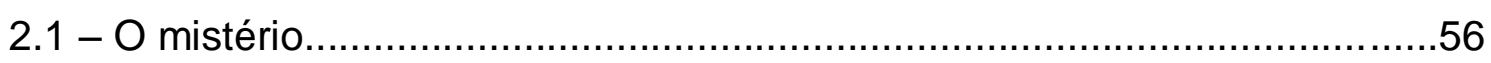

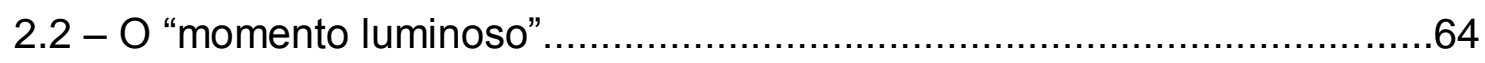

2.3 - A presença do duplo na manifestação do "eu" e dos "outros"...................69

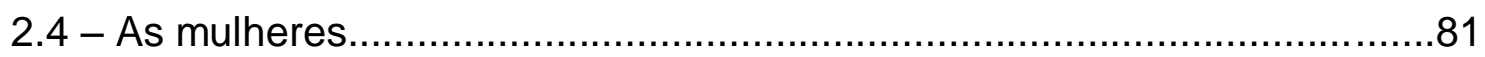

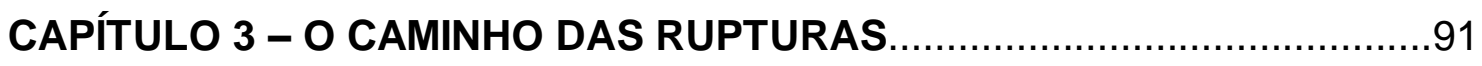

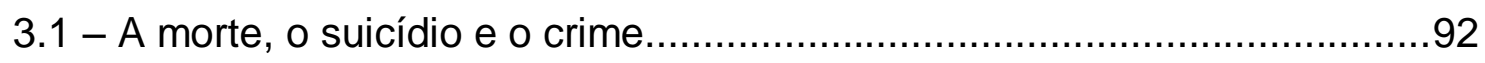

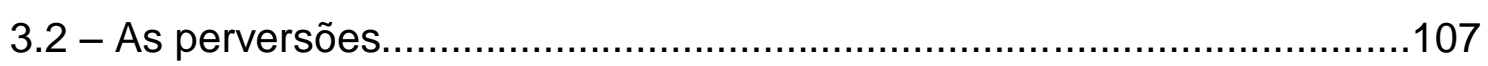

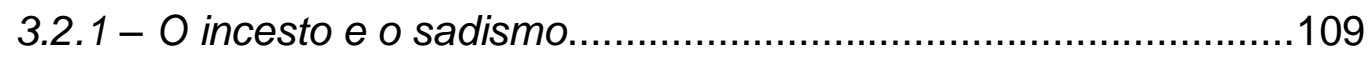

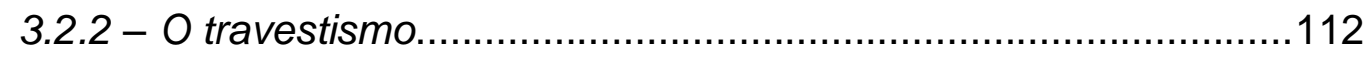

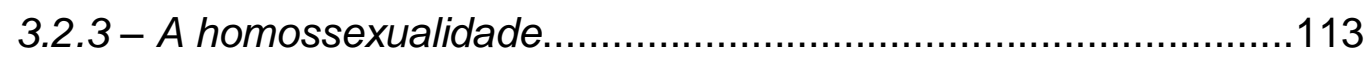

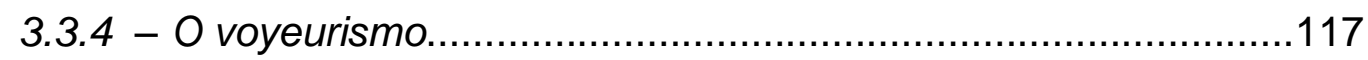

3.2.5 - Outros interditos..............................................................117

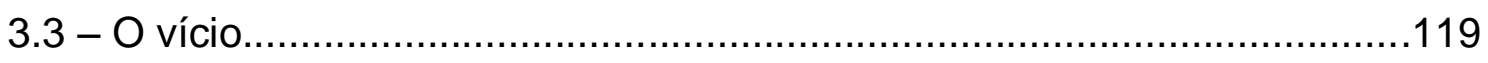

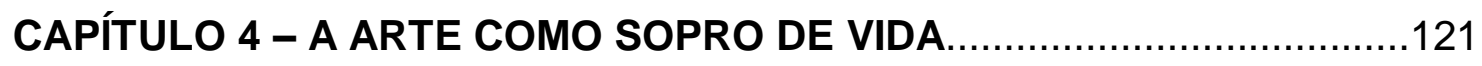

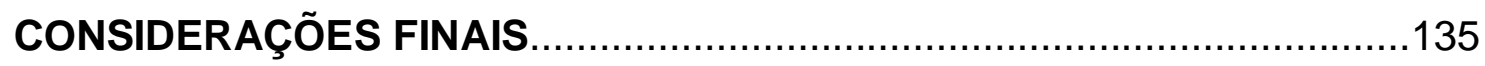

BIBLIOGRAFIA

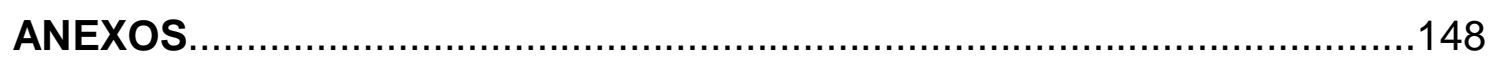




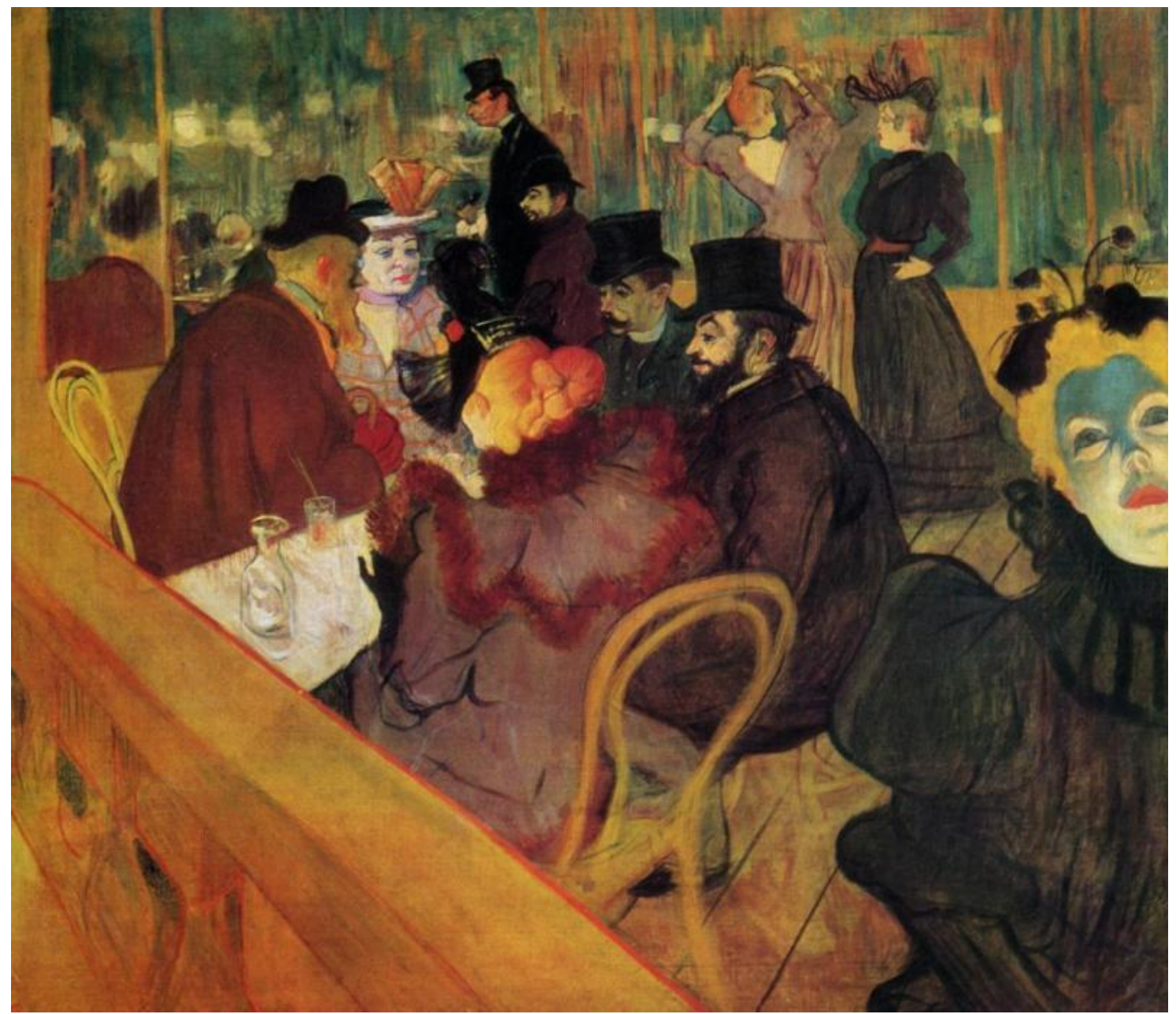

TOULOUSE-LAUTREC, Henri de. No Moulin Rouge.

"Sãa haras de te embriagares! Para nãa seres cama as escravas martirizadas da Tempa, embriaga-te, embriaga-te sem cessar! Cam winha, cam paesia, an cam virtude, a teu gasta."

Charles Baudelaire, Pequenas paemas em prasa. 


\section{INTRODUÇÃO}

Mário de Sá-Carneiro, ao lado de Fernando Pessoa e outros, foi um dos responsáveis pelo surgimento da Revista Orpheu, no primeiro trimestre do ano de 1915. Periódico que, com o advento da Modernidade nas letras portuguesas, foi a expressão mais fiel do ideário esotérico que atingia seu grupo idealizador, cujo grande mérito foi propor "[...] o rompimento com o passado [...]." (MOISÉS, 1994, p.239).

Foi pelas mãos de Luís de Montalvôr, Alfredo Guisado, Almada Negreiros, Fernando Pessoa e Mário de Sá-Carneiro, que Portugal despertou para a necessidade de inovação, e Orpheu cumpriu muito bem esse papel. Segundo Moisés (1994), a revista ganhou repercussão e foi bastante escandalosa, gerando a reviravolta cultural que seus fundadores tanto desejavam. Embalados pela obra de António Nobre, Fernando Pessoa e sua geração insistiram na criação de uma revista que fosse acessível aos novos poetas, e que oportunizasse a criação de espaço para uma proposta inovadora. O desejo dos autores era produzir uma revista em que a poesia substituísse "[...] os mitos, transformando-se, ela própria, num mito." (MOISÉS, 1994, p. 240).

A edição número "1" teve direção de Luís de Montalvôr e, como conteúdo, os lendários poemas de Álvaro de Campos, "Opiário" e "Ode Triunfal", e "Indícios 
de Oiro", "Apoteose" e "Nossa Senhora de Paris", de Mário de Sá-Carneiro, além de outros.

A edição número "2" contou com a colaboração de Santa-Rita Pintor e direção de Pessoa e Sá-Carneiro e, deste último, foi ofertada a publicação de "Manucure". Álvaro de Campos continuou publicando e, nesta edição, escreveu uma série de poemas dedicados a amigos, dentre eles "Ao Sr. Mário de SáCarneiro".

Através da figura de Sá-Carneiro, mais precisamente com o sustento monetário de seu pai, que Orpheu ganhou as ruas, porém, com a decadência financeira em que a família de Sá-Carneiro se envolveu, o financiamento foi rareando a ponto de não ser mais possível manter o jovem rebento morando em Paris com suas regalias, tampouco custear o terceiro número da publicação. Assim, a terceira edição, embora pensada e elaborada, nunca chegou às ruas, pois, sem o financiamento e com a morte do jovem Sá-Carneiro, em 26 de abril de 1916, não logrou o êxito esperado.

Contrariamente a tudo que a tradição portuguesa literária fazia no momento, Sá-Carneiro negava o modelo, chamado por Leodegário A. de Azevedo Filho (Semana de Estudos SC, p.109), romântico-realista, instaurado por Eça de Queirós e Camilo Castelo Branco que, segundo Sá-Carneiro, era calcado na tríade "princípio, meio e fim". Ordem que perdeu completamente o sentido no conjunto carneiriano, sobretudo na obra A confissão de Lúcio.

Mário de Sá-Carneiro teve vida curta, com poucos momentos de real alegria, superados por muitas fases de profunda insatisfação consigo e com o rumo de sua existência. A profunda infelicidade fez com que ele adentrasse num universo de turbulências e conhecesse a fundo a existência infeliz e a degradação humana.

Dotado de uma capacidade imaginativa eficiente, mas sem grande reconhecimento no mundo pragmático, o autor foi se ensimesmando gradativamente e pôs fim ao seu sofrimento aos vinte e seis anos de idade, sem deixar para trás amores, filhos, família, trabalho. O muito que construiu foi 
dotado de alguns poucos laços com amigos que puderam conhecer a gênese de sua criação.

Filho único de um pai ausente, órfão de mãe, financeiramente abastado por quase toda a vida, mas falido no final dela. Estudante de um curso nunca frequentado, artista amante de Paris, mas oficialmente residente em Lisboa, obeso e sexualmente não realizado. Todos estes fatores contribuíram para sua entrada em uma literatura voltada para o lado mais obscuro da existência humana: o mal.

Com as considerações acima, apresentamos a proposta do nosso trabalho, cujo objetivo é investigar como a "literatura do mal" é representada pelas personagens e eus da obra carneiriana. Nossa análise da obra de Sá-Carneiro, na perspectiva de perceber a representação do mal, tem como referência as contribuições apresentadas por Martin Heidegger (1889 - 1976), na obra Ser e Tempo; George Bataille (1897 - 1962) em A literatura e o mal; e Elizabeth Roudinesco (1944) em A parte obscura de nós mesmos - Uma história dos perversos.

Iniciamos o trabalho com a perspectiva de uma busca pelo que chamamos de mal e suas possíveis acepções, sempre deixando clara a dificuldade de conseguirmos chegar definitivamente a uma definição, mas baseados nos apontamentos de George Bataille configuramos a ideia de mal na perspectiva de verificar suas consequências no comportamento humano.

Nesta seara adentramos à ideia de que a massificação cultural do final do século XIX impôs ao homem da época uma dificuldade de se reconhecer como indivíduo, numa sociedade que crescia a olhos vistos e que estava imersa na mecanização oriunda dos avanços tecnológicos. Nesta crise de identidade e na sua multifacetação, em virtude do novo contexto político-econômico, é que está inserida a obra de Mário de Sá-Carneiro.

Martin Heidegger, em sua obra Ser e Tempo, de 1927, aponta alguns dos principais problemas no que tange aos estudos do homem e suas relações com 
o mundo, consigo mesmo e com os outros homens. Nesta perspectiva, Heidegger relata que, historicamente, o homem apresentou o que ele denomina de esquecimento do ser. Com esse entendimento, o autor faz referencia à necessidade de se retomar os estudos sobre homem pela vertente da sua relação com o objeto. Uma forma de relação que foi relegada a segundo plano por quase toda a história ocidental.

Inserido na sociedade europeia do final do século $X I X$ e início do $X X$, Martin Heidegger (2011) apontou em suas reflexões como o homem, cada vez mais inserido na sociedade que valoriza a posse material, na qual o pragmatismo é a filosofia que move o mundo, agia, percebia e constituía sua individualidade. Dotado de um sentimento de preocupação ${ }^{1}$, a vida em uma sociedade de massa se mostrava impetuosamente marcada pela impessoalidade. A sociedade passou a consumir produtos fabricados em série, as pessoas eram vistas pela óptica de sua capacidade de produção, pelo que eram capazes de oferecer socialmente e não pelas suas idiossincrasias. Todas estas situações, somadas a uma rotina cada vez mais extenuante de trabalho e horários rígidos, uma busca pela eficiência e acúmulo de produção, fizeram com que o homem do final do século XIX desse sinal de significativa perda de individualidade.

A belle époque, segundo Kujawski (1991), com todos os seus progressos, o advento da luz elétrica, o transporte de massa e o incentivo ao consumo, deu ao homem da época uma falsa sensação de completude, pois o indivíduo passou a ser caracterizado por sua capacidade de ter e adquirir bens e não mais por suas particularidades. Naquele período, ficou clara a transferência da representação da individualidade da interioridade do ser para o acúmulo das coisas. Nesse contexto, Heidegger afirma que o indivíduo deixou de se mostrar de dentro para fora, para executar exatamente uma ótica oposta, a que vai do objeto para o ser e não a do ser para o objeto ("ente").

\footnotetext{
${ }^{1}$ A preocupação não é bem vista por Heidegger (2011) na medida em que ele a vê como uma forma hipócrita de se colocar no papel de outro, o que nesta medida é uma impessoalidade, pois se preocupar demasiadamente com os outros, com o que as pessoas sentem e pensam, é uma maneira de abandonar seu projeto e, assim, sua própria existência.
} 
Considerando o homem como único ser que pensa em sua condição de ser, Heidegger (2011) debruça-se na relação do "ser" e do "ente" e na sua consequência mais evidente: a de que a vida do homem perdeu sua condição de autenticidade, ao ceder espaço para uma vida banal, inautêntica em virtude da alienação, da falta de consciência.

A vida inautêntica, a que se refere Heidegger, está ligada aos seres que, por meio das pressões e ações cotidianas, sufocaram seus projetos existenciais. Ela se dá pelo excesso de compromissos e obrigações impostos pelo cotidiano, que conduzem o homem a uma vida repleta de tarefas e obrigatoriedades, o que faz com que ele não seja capaz de voltar-se para si mesmo, mas, que se distancie de seu ser e passe a ser tratado por si mesmo como mais um "ente" posto no mundo. Esse tipo de sociedade é aquela que privilegia o homem visto dentro de um processo de massificação e nivelamento.

A reificação do homem é fruto desta cotidianidade, pois suas características individuais têm menos espaço neste novo mundo, um mundo em que as pessoas acabam, por força das circunstâncias, se comportando de maneira semelhante. É a cotidianidade que imprime ao homem a inautenticidade, afastando-o de seu "ser" pela ocupação com os "entes".

A existência humana acaba revelada socialmente, muitas vezes, de maneira bem homogênea, mascarando desejos, características, intenções. Os poucos seres que são sensíveis à necessidade de se afastarem deste tipo de vida são aqueles tocados pela angústia. Uma sensação de desconforto, que Heidegger define como:

A angústia não deixa mais surgir uma tal confusão. Muito antes, perpassa-a uma estranha tranquilidade. Sem dúvida, a angústia é sempre angústia diante de..., mas não angústia diante disto ou daquilo. A angústia diante de... é sempre angústia por...., mas não por isto ou aquilo. O caráter de indeterminação daquilo diante de e por que nos angustiamos, contudo, não é apenas uma simples falta de determinação, mas a essencial impossibilidade de determinação. Um exemplo conhecido nos pode revelar esta impossibilidade. (HEIDEGGER, 1969, p.31) 
Como aponta o autor, o ser angustiado, embora sempre manifeste sua "angústia por..." não é capaz de pontuar exatamente sua origem e nem tampouco seu objeto em si. Sabe-se apenas angustiado por algo que não é possível entender. Em geral, o resultado dessa angústia é o tédio, um não saber bem o porquê do desconforto sentido. Esta é a diferença entre o que o autor aponta como angústia e o temor. O "temor" é um medo de algum ente específico, já a angústia não. Essa angústia é a presença do "nada" para o ser, "A angústia manifesta o nada." (HEIDEGGER, 1969, p.32).

Característica de poucos, a angústia, oriunda da consciência de si mediante um mundo de não valorização das individualidades, em que as relações estavam centradas na figura do "ente" e não do "ser", é vista pelo autor não como algo negativo, como é tomada pelo senso-comum, mas como uma força capaz de levar a possibilidades. É a consciência que proporciona a angústia, pois é ela que faz com que o homem perceba que é um "ser" e não um "ente", que possibilita sua retirada da condição de "coisa" para a de "ser", a sua inserção na ideia de que é um sujeito e não um objeto. É por meio dela que o homem é capaz de se libertar da alienação que lhe é imposta, pois o mesmo se desvincula das suas obrigações cotidianas e passa a se voltar para si e fazer uso da sua liberdade, liberdade esta que pode transformar sua existência em uma vida autêntica.

É através da angústia e da preocupação que o homem "[...] localiza a verdadeira possibilidade da virada da existência humana, a possibilidade do homem sair da inautenticidade, na qual ele geralmente vive, e assumir a autenticidade." (WERLE, 2003, p. 110).

Os poucos que são tocados pela angústia são aqueles capazes de se voltarem para si e perceberem sua necessidade de se libertarem da banalização. Ao realizarem isso, vão em busca de uma vida mais autêntica, mais original, singular, ainda que esta singularidade esteja presente na morte pois, para o autor, a única verdade inquestionável na existência humana é a morte. É na morte que a liberdade plena se configura, pois ela é o momento mais singular e individualizado que acomete o homem. Não há como vivenciar a morte de 
outro, não há como prever e experimentar a sensação da morte e depois refletir sobre ela, não há representação. É por ser uma condição irrefutável que ela propicia a ação do homem. Sua possibilidade gera pressão para a execução de um projeto existencial que faça com que o homem escape da banalidade, pois, se o mesmo se mantiver intrincado no cotidiano, sua tendência é a da pura negação da mesma ou a aceitação resignada de que nada se pode fazer perante ela.

Quando o homem se coloca no mundo, Heidegger (2011) denomina este homem como um "ser-no-mundo" e, dessa maneira, passa a apontar que este ser é o responsável por seu "projeto". A criação e realização do projeto são, em última instância, as tarefas centrais de realização do ser, pois é através da realização de seu projeto existencial que o homem existe, não apenas como um "ente", uma coisa posta no mundo, mas sim como um ser que é capaz e consciente de sua vida no mundo.

Os estudos das relações ontológicas e ônticas são ferramentas para uma melhor compreensão da obra de Mário de Sá-Carneiro, uma vez que esta apresenta algumas das aflições estudadas pelo filósofo alemão como a presença da angústia e da consciência que o impulsiona a sair em busca de uma vida autêntica, desta forma enveredamos pelo conceito de maldade e suas implicações.

O primeiro capítulo desta tese identifica questões que se referem ao mal, no que tange à necessidade que este tem de uma ambientação diferenciada para se configurar. Dotados de consciência, alguns homens vivem a angústia de se questionarem a todo instante sobre sua própria existência e sobre a necessidade de se manterem fieis aos seus próprios projetos de vida e não às leis e ações cotidianas que the são atribuídas e que muitas vezes são formuladas apenas tomando como base a tradição social. Dotados da consciência desta situação, uma das possibilidades de suportar a vida é a criação de situações evasivas, em que o real e o ideal passam a caminhar lado a lado, sendo impossível a determinação exata de onde está um ou o outro. É possível verificar na obra de Sá-Carneiro meios de evadir-se para outras 
esferas. O escapismo, por ela apresentado, se dá pela manifestação da crise da identidade e seus desdobramentos, pela criação de outras realidades e pela idealização de espaços, pois estas criações possibilitam a concretização de ações que se caracterizam como más.

No segundo capítulo, o tema passa a ser o mistério, pois este é o tom dado a muitas das narrativas e dos poemas carneirianos. Nele, nos detemos a encontrar as marcas que nos remetem a esse universo. Partindo das palavras de Charles Baudelaire (1997), que não acreditava ser adequado tentar explicar o que vinha a ser o próprio mistério, buscamos perceber como as ações das personagens nos remetem a essa esfera e como dentro dela estas ações se configuram como ações do mal. Temos, nesta perspectiva, o mistério manifestado pela busca de momentos luminosos e singulares na vida, pelo duplo, que a toda hora nos coloca o questionamento quanto à existência (ou não) de personagens, ou ainda, na recorrência de tipos recorrentes nos poemas. O mistério manifesta-se também nas mulheres sensuais e exóticas que surgem por toda parte, com suas danças de serpente trazendo a dor, a traição, a doença e a morte, sendo elas o retrato feminino da mulher fatal, da mulher maléfica.

No terceiro capítulo, a abordagem recai na questão da morte e suas variáveis, como o suicídio e o crime, mas estes ligados principalmente à perversidade e a sua relação com o mal. A perversidade aqui se mostra pelo uso do escapismo e do mistério como formas de configurar a vida pela ausência de uma moral que possa tolher o homem, fazendo com que este use de sua liberdade para viver o que preciso fosse em busca de instantes singulares, vidas repletas de artificialismo, sem temer as consequências, cabendo uma reflexão sobre a morte, o suicídio, o crime, o incesto, o homossexualismo e outros interditos que podem sugerir uma ligação com o mal.

No quarto e último capítulo, terminamos com a junção das ideias apresentadas nos capítulos anteriores, da fragmentação da identidade, da duplicação, da fuga para outra realidade, da criação de uma vida de mistério, da presença da morte e das perversões como geradores de um ideário artístico criado por Sá- 
Carneiro, um ideário artístico que, entre tantas características, se configura como um depositário do mal. O capítulo versa sobre a arte e sua função dentro desta realidade maléfica e singular apresentada na poética carneriana.

As relações entre o escapismo, o mistério, a morte, as perversões e a arte são os subsídios para a inscrição da obra de Mário de Sá-Carneiro como um receptáculo daquilo a que chamamos de "literatura do mal" e que vem a ser o objeto de análise desta tese. 


\section{CAPÍTULO 1 - ESCAPISMOS: UMA VEREDA PARA O MAL}

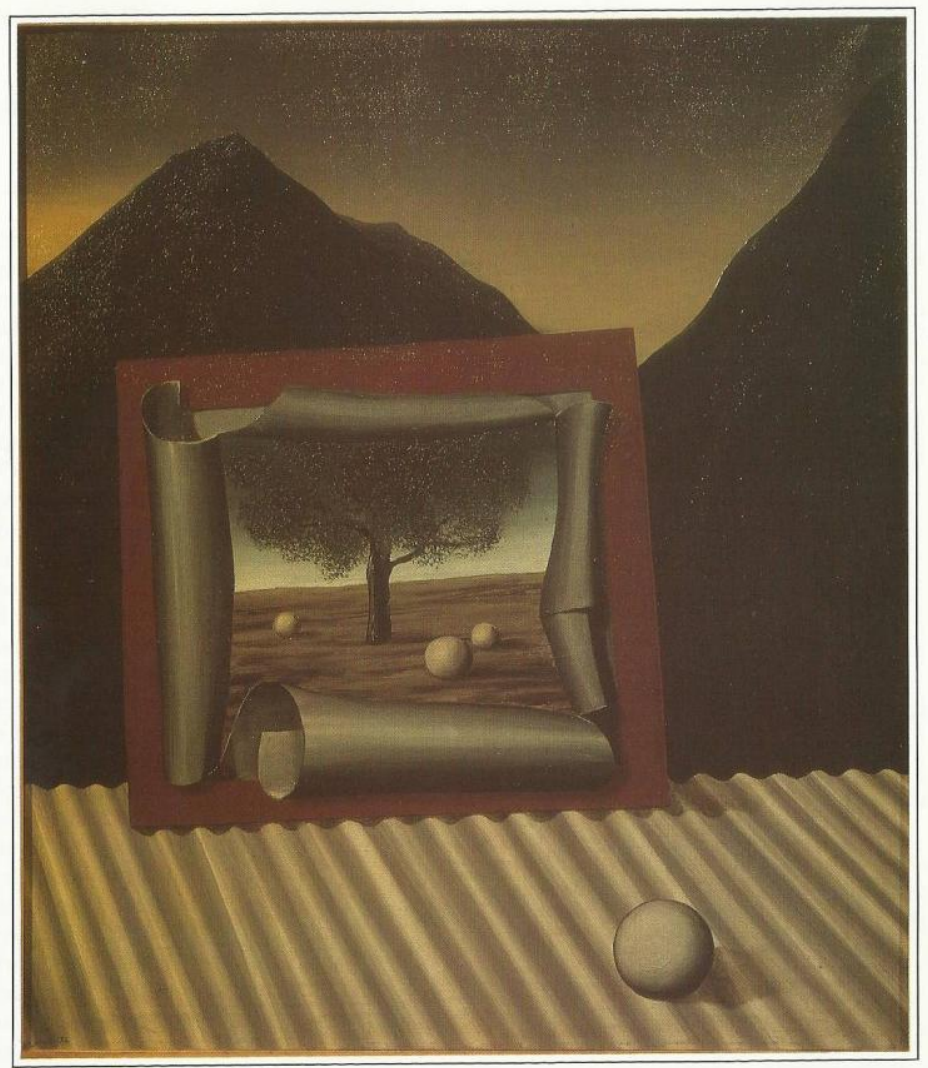

MAGRITTE, René. Os sinais da noite.

"Que valar teria um deus que nãa canhecesse a ira, a vingança, a inveja, a desdém, a trapaça, a vialência?"

Friedrich Nietzsche, $\mathcal{O}$ Anticrista. 


\section{1 - Um olhar sobre o Mal}

Na obra de Mário de Sá-Carneiro podemos encontrar poemas, contos, novelas, peças de teatro, além de textos de outros gêneros, como cartas, rascunhos de críticas, entrevistas etc. Através desses escritos, o autor nos possibilita 0 acesso a uma esfera de mistério, profanação, dúvida, multiplicidade, além... Um exame desses textos revela uma forte recorrência de Sá-Carneiro a assuntos como, por exemplo, o suicídio, a morte, o amor não realizado, a arte, a fé, a violência e o erotismo.

Sobre os temas acima, George Bataille (1998) afirma que se configuram como manifestações do mal na literatura, e consideramos um estudo sobre isso bastante desafiador, até pela própria complexidade que envolve o conceito da palavra mal e suas várias conotações. O Dicionário Houaiss da Língua Portuguesa, por exemplo, atribui mais de trinta acepções à palavra, sendo uma delas a de que o mal é aquilo "[...] que prejudica ou fere; o que concorre com o dano ou a ruína de alguém ou de algo; o que é nocivo, desastroso para a felicidade ou o bem-estar físico ou moral; infelicidade". (HOUAISS, 2004, p. 1815-1816).

Podemos afirmar, portanto, que o mal está em oposição ao bem que, por sua vez, é relativo à virtude, à honra, à moral. $\mathrm{O}$ mal é aquilo que gera ruína, que prejudica, que é nocivo, que traz o infortúnio, a doença, a desgraça. Pode ser ainda aquilo que ataca os que sofrem a perda de um amor ou a maledicência, ou, ainda, o mal é o maligno personificado.

A dificuldade que percebemos em entender o mal está menos em sua definição do que no significado que ele pode assumir no âmbito da subjetividade. Como determinar aquilo que machuca ou fere, alguém que causa infelicidade nas pessoas, mas que não tem fonte objetiva? Assim, a questão é menos sobre o que é o mal, em face do que causa o mal ao ser humano.

O mal é um assunto que sempre esteve presente na pauta das discussões filosóficas. Desde Sócrates até os dias atuais, se discute na filosofia, na 
literatura e em muitas outras áreas do saber questões relativas ao bem e ao mal, seja de maneira direta ou pelo caminho da ética. O que percebemos no exame histórico dessas discussões é que, sob o ponto de vista da objetividade que envolve a vida dos seres humanos, a discussão sobre o mal é feita em comparação com o conceito do bem, e está sujeita à variação temporal e cultural. Esta contingência sobre o conceito e a fonte de mal revela sua gênese necessariamente humana.

Segundo Ullmann (2010), historicamente o mal, ação que afeta o ser humano, é visto com origem em três vieses: mal físico, moral e metafísico. O mal físico pode ser desencadeado de duas maneiras: objetiva - por enfermidade ou perda de bens - e de modo subjetivo - por sentimentos oriundos de situações vividas, males como decepção amorosa, raiva, frustração, medo, ansiedade e que se revelam nas emoções (tremor, sudorese, agitação corporal, rubor, aumento de frequência cardíaca, choro). O mal moral "[...] reside no desvio voluntário da norma de moralidade, que é a razão, nas ações livremente postas." (ULLMANN, 2010, p.11). Neste aspecto, ele é a negação às regras construídas pelos homens. E, por fim, o mal metafísico é aquele cuja gênese está nas manifestações da natureza, mas "[...] não representa nenhuma injustiça da parte de Deus." (ULLMANN, 2010, p.11).

Em relação à literatura, o mal surge associado à ideia de liberdade, intimamente ligado à vontade, vontade esta que "[...] é uma faculdade, capaz de produzir uma ação; sendo livre, pode igualmente não produzi-la." (ULLMANN, 2010, p.18). Desta forma, cabe ao homem, em suas ações, escolher entre o bem ou o mal.

Como considera Platão (1983), o ser humano é responsável por tudo o que faz, pois ele sempre pode decidir fazer o bem ou o mal. O filósofo ainda acredita que o bem e o mal são intrínsecos ao sujeito, não é algo derivado do meio externo. O entendimento deste é o de que o homem é naturalmente dotado de capacidade para saber o que é o bem e o que é o mal, podendo escolher entre um e outro em suas ações. Nesse sentido, a capacidade superior do indivíduo está em superar seu instinto de ser mau, de optar por fazer o bem (e não o 
mal), pois ele possui o controle sobre suas decisões - assim como a consciência de que seus atos podem ser bons e resultar em consequências boas, ou serem maus e resultar em desdobramentos desagradáveis aos outros. Platão concebe o homem com liberdade para decidir de que forma atuar na sociedade e, consequentemente, mostra que este é responsável pelas suas ações.

Embora o homem seja apontado como um ser gregário, que deseja viver em sociedade, ele, naturalmente, na ausência da lei, tende a satisfazer suas vontades, em detrimento do bem alheio. Assim, podemos considerar que a liberdade gera possibilidades de escolhas particulares e elas podem conduzir ao mal de outrem, desta maneira, George Bataille (1998) considera que o homem é um ser descontínuo no que tange à sua existência. A descontinuidade para ele é a consciência do homem quanto a sua individualidade, unicidade e solidão. Percebendo-se um ser individual, que é único e sozinho em suas necessidades, Bataille aponta que a angústia de não termos a possibilidade de nos ver espelhados nos outros ou de nos sentir confortáveis com a presença do grupo ou, ainda, de perceber que a solidão é um sentimento persistente é que faz o autor concluir que o homem tende à "busca da continuidade perdida". Essa busca nada mais é que a tentativa de superação da descontinuidade, ou seja, a busca pela formação de vínculos com seus pares na ilusão de ser menos individualista, só e diferente. Posto isto, o problema se dá pela luta travada pelo indivíduo para ser um ser contínuo em meio a uma vontade maior de saciar seus desejos, pois os valores individuais costumam vir em primeiro plano e, segundo o autor, todos os atos que neguem esta assertiva são artificiais. Quando o homem age de maneira a colocar o valor individual antes das necessidades coletivas, ele promove uma mudança, uma revolução e, é a partir disso que a vida ganha uma dimensão diferenciada que, genericamente, é vista como uma dimensão sublime.

É pela busca do sublime, do grandioso, do magnífico que, muitas vezes, as ações humanas se manifestam pelo viés maléfico, pois a descontinuidade acaba prevalecendo e emergindo e, desta forma, possibilitando uma demanda pelo prazer, pela satisfação de um gosto. 
Em relação ao campo artístico, isto pode ter efeitos maiores, pois, segundo José Augusto Mourão: "Não há poeta que não tenteie a transcendência em seus poemas." (1992, p.130). Na busca pela transcendência, por uma vida sublime e autêntica - que é tida como condição inerente aos artistas - 0 homem acaba, muitas vezes, rompendo com as ideias e com os comportamentos baseados na moralidade e parte, assim, para ações calcadas nas escolhas individuais, que lhe garanta o prazer e a desejada autenticidade.

Ao abordarmos a discussão sobre o mal, é lugar-comum a circunscrição do pensamento a temas como violência física, assaltos, roubos, latrocínios etc. Entretanto, no que concerne à literatura, o mal passa ao largo dessas ações. No contexto literário, o mal não se deleita em motivos materiais, pois este não é o objetivo último de quem o pratica, mas sim no gozo do mal em si mesmo. $\mathrm{Na}$ literatura, o mal envolve a ideia do prazer e, assim, encontramos a presença do sadismo.

[...] no sadismo, a questão é gozar a destruição contemplada, sendo a destruição mais dolorosa a morte do ser humano. 0 sadismo é o verdadeiro Mal; se se mata por uma vantagem material, não é o verdadeiro Mal; o Mal puro é quando o assassino, por lá da vantagem material, goza por ter morto. (BATAILLE, 1998, p.10)

Caímos, então, naquilo que alguns chamam de moral, mas neste contexto específico não cabe pensar no simples conjunto de regras que orientam a conduta das pessoas, pois não podemos considerar que as ações descritas pela literatura carneiriana sigam (ou não) algum conjunto de moralidade determinada. O que temos nela não é "[...] a ausência de moral" (BATAILLE, 1998. p.6), mas “[...] uma `supermoral”." (BATAILLE, 1998. p.6). "O mundo do texto, porque é mundo, entra necessariamente em colisão com o mundo real, para o 're-fazer', quer o confirme, quer o negue.” (MOURÃO, 1992, p.136).

Nessa perspectiva, as regras são conhecidas e, contrariamente ao que poderia ser pensado, elas não são desobedecidas exatamente, são ignoradas, pois não 
há a noção de culpa em quem não as cumpre. A servidão ao cumprimento das regras, segundo Bataille $(1987,1998)$, é vista como uma agenciadora do bem. Já a liberdade, concebida pela vontade, possibilita a concretização do mal, como afirma Luigi Pareyson.

\begin{abstract}
A liberdade de quem se quer afirmar a si mesmo para além da lei moral e chega ao ponto de esquecer a distinção entre bem e mal, por um lado, pode transformar-se em instinto de destruição e, em por outro, pode apresentar-se como gosto pela infração, como prazer pela transgressão, como gozo pela violação da lei. Nasce aqui a perversão propriamente dita, pela qual se faz o mal não só pela deliberada vontade de infringir a lei, mas também pelo prazer desta consciente e voluntária transgressão: fazer o mal pelo mal, "ofender pelo gosto de ofender", "ser feliz por cometer crimes". (PAREYSON, 2012, p.59)
\end{abstract}

Essa ausência de moral, ou supermoral, esse prazer consciente e voluntário pela transgressão, se dá por uma visão muito particular de se lidar com o mundo. Num processo de negação dos princípios judaico-cristãos, os homens e as mulheres da obra carneiriana podem ser considerados, como conceitua Roudinesco (2008, p.86), "representantes dos perversos". Com suas leis que escapam aos homens comuns, muitos deles mostram comportamentos que representam o "triunfo da animalidade sobre a civilização" (ROUDINESCO, 2008, p.86). Se, na história da humanidade, por um bom tempo ser perverso era uma situação patológica, dentro da literatura isso ganhou certa aceitação, talvez até uma notoriedade, com as obras de alguns grandes escritores.

Excluídos da ordem procriadora e estigmatizados como a parte maldita das sociedades humanas, os homossexuais de antigamente - Oscar Wilde, Proust e os personagens de seus romances - eram reconhecíveis, identificáveis, marcados, estigmatizados. Formavam [...] o famoso povo dos perversos: uma "raça maldita", aparentada, aliás, como observava Proust, às mulheres (a "raça das tias") ou aos judeus. (ROUDINESCO, 2008, p.193)

Repleto de personagens que em muito se assemelham ao tão temível universo da homossexualidade e do incesto, estes não são os únicos vieses que atraem e aproximam a obra carneiriana do universo do mal. Temos na obra a presença 
também de assassinos, torturadores, dissimuladores e depravados. Ou seja, um conjunto repleto de personagens com um potencial maléfico e que não parecem fazer esforço algum para conterem esses instintos, o que é bem natural, pois segundo Hauser "[...] o mal ocorre sem esforço, quer dizer, naturalmente, ao passo que a bondade é sempre o produto de um plano e de um propósito, sendo, portanto, artificial e antinatural." (2000, p.912). A naturalidade da maldade é também afirmada por Pareyson em seus estudos a respeito da obra de Fiódor Dostoiévski, em que o autor afirma que "O mal está sediado tão a fundo no homem, que em todos existem instintos malvados: a própria natureza do homem tende ao mal." (PAREYSON, 2012, p.89).

Sem fazer grandes esforços para se colocar dentro de uma vida configurada como do bem, a obra de Sá-Carneiro tem como um de seus recursos possibilitadores desta realidade a fuga e o escapismo. É por meio da criação de uma realidade paralela, do desdobramento da identidade e da idealização de espaços que se torna possível enveredar pelos caminhos do mal. Um caminho que só se concretiza caso o indivíduo se desprenda das convenções morais comuns na sociedade e passe a dar vazão, sem censura, aos seus mais íntimos pensamentos e vontades, fazendo com que estes passem a se tornar ações, ainda que sabendo que estas ações, muitas vezes, vêm agregadas à ruína, ao infortúnio, à doença, ao nocivo, ou seja, que sejam ações que possam ligá-lo ao mal.

\section{2 - A identidade e a alteridade}

A sala do castelo é deserta e espelhada.

Tenho medo de Mim. Quem sou? De onde cheguei?... Aqui, tudo já foi... Em sombra estilizada, A cor morreu - e até o ar é uma ruína... Vem de Outro tempo a luz que me ilumina Um som opaco me dilui em Rei...

(SÁ-CARNEIRO, 1995, p.75)

O verso inicial do poema "Epígrafe", que abre Indícios de Ouro, está estruturado de maneira simples com um sujeito explícito, seguido de um 
predicado nominal. A mesma estrutura básica e simples de representação da língua coloca-se em oposição à complexidade do assunto abordado no texto. Deparamo-nos com um eu lírico diante de questionamentos primordiais, que acompanham o homem desde o começo dos tempos: Quem sou? De onde venho?

O "tom" do poema nos é dado inicialmente pela afirmação de que "A sala do castelo é deserta e espelhada.". A ideia de força, defesa, abrigo, segurança e tradição dada pelo substantivo "castelo" se mostra em contradição com o predicativo "deserta e espelhada", que nos remete a um universo de espelhos, suas múltiplas imagens e desdobramentos colocados lado a lado com o deserto e sua ideia de solidão, vazio e infertilidade. Num desabafo, o eu lírico assume: "Tenho medo de Mim". O que encobre este eu a ponto dele próprio temer a si? Que segredos estão lá guardados? Seria esse medo de si oriundo do desconhecido, da falta de segurança em se precisar quem se é? Seria o medo de se perceber espelhado, multiplicado e ao mesmo tempo seco, desértico? Seja como for, o que temos aí é o aparecimento das mais primordiais questões ontológicas: "Quem sou? De onde cheguei?...".

A identidade tem sido motivo de estudos por toda a história da humanidade. Ela é uma das grandes questões de várias áreas do conhecimento. A Antropologia, as Ciências Sociais, a Filosofia e a Psicologia há muito se debruçam sobre o fato, para tentar decifrar este mistério. Perpassando pelo estudo do "ser", da "existência" e da identidade, dos gregos aos dias de hoje, não há unidade no pensamento. Um dos estudiosos do tema foi Martin Heidegger (1889 - 1976), que buscou a fundo as questões do "ser" e, naturalmente, do "reconhecimento da identidade". Sua obra Ser e Tempo, passou a ser um dos pilares de qualquer estudioso que se pretenda refletir sobre o "ser", suas funções e a maneira com que este "ser", se colocado na vida mundana, se apresenta e comporta.

Não cabe, nem se tem a pretensão de levar a fundo estas questões e nem um pensamento tão amplo e complexo quanto o heideggeriano, mas faz-se mister 
trazer parte de seus conceitos para que, à luz deles, sejam formulados alguns apontamentos.

Heidegger (2011) parte do princípio básico de que o estudo do ser deve se iniciar pelo estudo do homem, pois ele, além de ter existência no mundo, ainda é capaz de refletir sobre ela. Esta seria a diferença básica e crucial entre aquilo que o alemão denomina por "ser" e "ente".

Para o termo "ente", Heidegger (2011) considera tudo o que existe, todas as coisas que são, sejam elas materiais (uma porta, uma flor), quanto imateriais (um sentimento, um pensamento). Já o termo "ser" é muito mais amplo e complexo, pois ganha variações e não há uma unanimidade em sua tradução para o português, nem ao menos uma concordância de sua significação. Usaremos para esta tese, os desdobramentos propostos na obra de Christian Dubois (2004) sobre o conceito "ser", como "ser-aí", "ser-no-mundo", "ser-pramorte" entre outras.

O início da discussão de Heidegger a respeito da condição do ser no mundo se dá muito pela percepção do tipo de sociedade que o final do século XIX apresenta. Embebidos pela inicial euforia trazida pela belle époque, que oferecia ao homem comum:

Privilégios de conforto antes restritos às minorias, como banheiros privados, luz elétrica, geladeira, telefone, difundem-se entre a pequena burguesia e a situação do proletariado torna-se menos aflitiva. Mais importante que a posse efetiva dos bens, foi a expectativa geral que se criou de que, finalmente, chegava o dia em que todos os homens, sem distinções, teriam garantido seu lugar ao sol. (KUJAWSKI, 1988, p.2)

Consagrada como um período "[...] efêmero, luminoso e ambíguo." (KUJAWSKI, 1988, p.2) a belle époque viu-se estilhaçada com o advento da primeira guerra mundial. 
Viu-se que esta se fundava numa grande ilusão, num excesso injustificável de otimismo. [...] A paz eterna recebeu um golpe mortal. A Revolução Russa de 1917, na Rússia, patenteou a força vulcânica das insatisfações sociais que lavrariam no subsolo do continente europeu. Sobretudo se constatou na carne, de forma catastrófica, que o Progresso não passava de mitificação e que o avanço tecnológico não correspondia, de modo algum, ao aperfeiçoamento moral da humanidade. (KUJAWSKI, 1988, p.2)

Massacrado pela constatação de falência do ideal de paz e igualdade, mas sem perspectiva de uma mudança mais significativa, o homem europeu da época se mostra um simples cumpridor de tarefas, que estava a todo o momento contido numa rotina célere, que se impunha pela necessidade de cada vez mais consumir e se colocar a serviço desta sociedade voltada para a imagem, para o espetáculo, em que ficava impossível constatar e diferenciar os limites do real e do espetacular.

Como pensar então na existência humana - que se mostra tão complexa se esta parece tender à igualdade, à mesmice, ao espetacular? Segundo Heidegger (2011), alguns homens passam a desenvolver aquilo que ele denomina como "preocupação". A preocupação é uma força que move o homem e em alguns deles ela se transforma em "angústia".

Em meio à diversidade de circunstâncias inautênticas, que encerram o homem na vida cotidiana e limitam suas chances de encontro verdadeiro rumo à autenticidade, encontra-se, porém, um sentimento que é capaz de desarraigar o homem de tal situação alienante. Este sentimento, que não é proveniente de uma circunstância ou mediação externa ao próprio Dasein, mas inerente a ele, Heidegger chamou-o simplesmente de angústia. (NAVES, 2009, p.68)

Cabe à angústia fazer com que o homem saia da situação de mero reprodutor de vivências, para construtor de suas próprias vivências. A saída de uma existência fortemente baseada na igualdade com seus pares, fundada no cumprimento das obrigações sociais, desprovida de uma genuína autenticidade leva o homem ao grande e dificílimo objetivo de sua trajetória enquanto ser: conquistar uma vida autêntica, ser dono de seu projeto. 
A expressão "diversidade de circunstâncias inautênticas" é uma ideia que está presente nos escritos de Heidegger, pois ele se debruçou sobre os estudos do que chamou de "meios de ocupação". Os "meios de ocupação" são as atividades do "ser-ai" em sua vida cotidiana, que servem para identificá-lo através de uma função social perante seu grupo. Nessa instância, o "ser-aí" ganha a denominação também de "ser-no-mundo". Nesta dimensão, o homem busca uma identificação social e profissional e se relaciona com outros seres ao seu redor. "Vivendo em grupo, o Outro se torna parte decisiva na vida desse sujeito, que, conscientemente ou não, responde e toma decisões tendo em vista o ponto de vista daquele." (ALVAREZ, 2010, p.22). É deste processo de eterna troca com os outros "ser-aí" que o rodeiam, que advém 0 reconhecimento e, portanto, a identificação.

Segundo Heidegger $(2011,1969)$, existe uma tendência natural do homem de se reconhecer pela comparação com seus pares, levando a existência humana a uma condição de homogeneidade, de "rotinidade". "A estrutura fundamental do 'ser-no-mundo' é 'ser-com-outro', pois é a partir do outro que se forma a consciência do eu, a afirmação de si mesmo e da própria identidade." (NAVES, 2009, p.67).

Ao mesmo tempo em que notamos um indivíduo em busca de parceria para reconhecer sua própria individualidade, é possível notar um eterno conflito na aceitação e no reconhecimento desta, pois a aceitação da igualdade entre as características dos homens é, para alguns, motivo de desespero e de constatação de uma diferença que, muitas vezes, aponta para a inferioridade dos mesmos.

Aqueles que estão inseridos nesse contexto, sem nenhum tipo de reflexão quanto à sua trajetória de vida, aqueles que simplesmente apresentam a manutenção, aceitação e execução das responsabilidades pela sociedade imposta, têm aquilo a que Heidegger (2011) denomina como "vida banal", uma vida dentro de um padrão socialmente aceitável e esperada aos seres comuns. Já, em contraposição a estes, alguns seres, conscientes da rotina em que 
estão inseridos, da perda da autonomia de seus projetos de vida, partem a uma busca desenfreada por uma vida dada como "mais significativa", uma vida mais marcante, que não seja apenas protocolar, uma vida repleta de novidades e comportamentos desligados da rotina e da manutenção dos hábitos, uma vida mais dotada de singularidade, a ela dá-se o nome de "vida autêntica".

Cabe à liberdade e à capacidade de transcender fazer com que o "ser-aí" seja capaz de desejar e promover projetos individuais. Seguindo este pensamento, podemos encadear as ideias da seguinte forma: o "ser-ail" é dotado de "consciência" e isso the causa angústia, desta advém a necessidade de resoluções, que são baseadas na liberdade, podendo dar origem a uma "vida autêntica". Visto assim, resumidamente, fica constatado que é a angústia que gera a liberdade de escolher ações que construam uma vida autêntica.

A consciência - vista em oposição à ignorância - conquistada pelo "ser-aí" pode, para muitos, parecer um privilégio, pois é o princípio para a vida autêntica, mas seu custo costuma ser bastante alto. Dotado da consciência de estar posto num mundo que preza pelo acúmulo de bens, pela massificação, pela homogeneização dos comportamentos, a ignorância, a não consciência é a possibilidade do não sofrimento. A vida autêntica e sua clareza faz com que o ser se coloque numa eterna condição de dor, pois há um excesso de reflexões e, através de exaustivas análises, fica provável que o mundo se mostre insuficiente e é desta insuficiência que vem a necessidade da busca por uma vida que se difira da massa. A obra de Mário de Sá-Carneiro aponta para a presença de seres angustiados pela consciência do "não poder", do "não possuir" e do "não ser". A possibilidade do encontro de uma vida autêntica é dada a eles pela negação das tarefas cotidianas e pela aceitação de uma vida voltada para a arte, pois esta possibilita a entrada num universo de imaginação, devaneios, beleza, permissividade. Na arte não há freios, bloqueios, censuras, nela tudo pode e se realiza.

Numa seara tão complexa e múltipla, como a do reconhecimento do "ser-nomundo", seria ingênuo pensar numa definição única e definitiva do termo "identidade". E, menos possível ainda, pensar que o indivíduo a tenha como um 
conjunto único, coerente e harmonioso. Sobre isso, Marc Augé (2010) aponta que a identidade é naturalmente fragmentada, ela nunca é absoluta, pois advém da hereditariedade, da filiação, da semelhança, da influência do meio, entre tantas outras questões que recaem sobre o indivíduo. As tradições todas que nos formam também podem não nos identificar definitivamente, pois estamos em eterno contato com o novo e, desta forma, influenciamos e somos influenciados a todo instante por ele. Para tentar encontrar um termo que melhor represente esta individualidade, ele cunha "alteridade essencial ou íntima", pois acredita existir uma eterna dependência do indivíduo com a sociedade "[...] proibindo, ao mesmo tempo, dissociar a questão da identidade coletiva daquela da identidade individual." (AUGÉ, 2010, p.23). Neste jogo de identidade/alteridade, o indivíduo se identifica com a sociedade em que vive e torna-se, na mesma medida, a própria expressão dela, num jogo eterno de reflexos.

Em concordância com isto, Heidegger (2011) assegura que o "ser-aî" transforma-se em "ser-no-mundo", à medida que ele está num processo de eterna troca com os outros "ser-aí" que o rodeiam. Advém desta troca a necessidade eterna do "ser-aí" de estar em contato com outros seres, para poder se reconhecer e, portanto, se identificar. Esta identificação com os "seraí" mais próximos, esta busca pelo reconhecimento e a necessidade de aceitação são condições eternas mas, invariavelmente, vêm atreladas a uma dificuldade de se aceitar como igual e diferente de todos.

Como vimos, na modernidade, a identidade se mostra em xeque e, portanto, podemos ir muito além das indagações. As questões apontadas pelo texto carneiriano nos levam a divagar sobre a própria existência e os limites entre alteridade e identidade. Num universo dotado de tantas abstrações, nos deparamos com expressões puras de personagens e eus em plena contemplação de suas dúvidas. "Corro em volta de mim sem me encontrar..." (SÁ-CARNEIRO, 1995, p.59), "Perdi-me dentro de mim/Porque eu era labirinto,/E hoje quando me sinto/É com saudade de mim." (SÁ-CARNEIRO, 1995, p.61), "Tenho medo de Mim. Quem sou eu? Donde cheguei?" (SÁ- 
CARNEIRO, 1995, p.75), "Esta inconstância em mim próprio em vibração" (SÁCARNEIRO, 1995, p.83). Quem é o eu e quem é o outro?

"Eu-próprio o Outro"2 é nome do sexto conto de Céu em fogo. Escrito por um longo período de tempo, de 1907 a outubro de 1912. O texto apresenta uma espécie de "pequenos capítulos" delimitados por datas, que se supõe serem as datas da escritura de cada uma das partes. Na narrativa, encontramos um tom eminentemente confessional de um narrador que se coloca a pensar sobre quem ele é ("ser-aî"), sua integração com os outros ("ser-no-mundo") e seus "meios de ocupação". As questões ontológicas clássicas estão postas e está dado o gatilho para a dicotomia "vida banal/vida autêntica", além da aceitação resignada da dor oriunda da angústia.

Como o próprio nome sugere temos, no desenrolar da narração, um indivíduo que demonstra um profundo conflito consigo mesmo e, num segundo momento, um conflito com um Outro, apenas identificado por "amigo".

SOU UM PUNHAL d'ouro cuja lâmina embotou.

A minha alma é esguia - vibra de se elançar. Só o meu corpo é pesado. Tenho a minha alma presa num saguão.

Não sou covarde perante o medo. Apenas sou covarde em face de mim próprio. Ai!, se eu fosse belo...

Envergonho-me, de grande que me sinto.

Sou tão grande que só a mim posso dizer os meus segredos.

Nunca tive receios. Tive sempre frio. (SÁ-CARNEIRO, 1995, p.503)

O início do conto descreve, de maneira triste e depreciativa, quem vem a ser o eu/narrador. Ele se define como um "um punhal d'ouro", cuja lâmina estava embotada. Num reconhecimento de si através de uma imagem, o narrador opta pela de um punhal que, em forma de cruz, são armas brancas muito ligadas à ideia de morte trágica. $O$ objeto escolhido demarca uma primeira sensação exposta por ele, de sua inserção no mundo como alguém sem utilidade,

\footnotetext{
2 O título "Mário `Eu-próprio o Outro"' foi o nome dado à peça de teatro escrita por José Régio em homenagem a Sá-Carneiro, baseada no conto "Eu-próprio o Outro". Régio acreditava que o conto era fruto dos registros dos últimos momentos do poeta no quarto do Hotel Nice, de Paris, antes de se suicidar.
} 
alguém que, ainda que seja "d'ouro", de nada vale. É um primeiro apontamento que se mostra recorrente na obra do autor, o de uma identidade que se percebe "desperdiçada", sem o devido reconhecimento de seu valor.

Usando da mesma ideia expressa pela peça de teatro "Alma", composta em parceria com Ponce de Leão, o narrador segue sua descrição pontuando a separação entre corpo e alma, cujas partes se completam, mas não (necessariamente) mantêm correspondência. Ele apresenta uma "alma esguia", em contraposição a um "corpo pesado". Além de vistos separadamente, as partes não se completam, harmonizam ou sequer se toleram. Em desabafo, ele diz: "Ai!, se eu fosse belo...". Uma sonhada beleza e um corpo esguio seriam, provavelmente, um alento, mas sua ausência desperta o sentimento de uma inadequação de corpo/alma, explicitadas na vergonha que sentia de si mesmo. Vergonha, desconforto, descompasso só trouxeram ao narrador uma solidão profunda, deflagrada na expressão final do trecho: "Tive sempre frio.", que mostra que a solidão física e espiritual que sentia, o levou a um estado de morbidez, pois a vida por ele vivida o mantinha gelado a tal ponto que era como se ele já estivesse morto.

Na sequência do texto, surge uma imagem que se repetirá ao longo do mesmo e que, em muito, pode acrescentar à compreensão do desencontro existencial presente: "As janelas abertas continuam cerradas..." (SÁ-CARNEIRO, 1995, p.503). Diante da oposição entre abertas/fechadas, as janelas, o horizonte, do narrador se diminui, se restringe. Aquele que tem alma leve e pronta para fluir, para sair pelas janelas abertas de seu ser, vê-se preso, trancado, condenado no corpo obeso que o impede da plenitude. Ele nos conta "[...] fiquei sempre, nunca fui - mesmo quando me perdi." (SÁ-CARNEIRO, 1995, p.503) Mais uma vez, há a ideia da perda e, para confirmá-la, ele se utiliza de uma linguagem com vocabulário ora ligado à estagnação - "fiquei", ora à negatividade - "nunca", ora à durabilidade do instante - "sempre", para concluir pejorativamente que tudo isto somado, nada mais é do que o perder, e sua única conquista é o fracasso. 
Angústia posta pela percepção de uma identidade que não lhe agrada, o que vemos no texto é um dualismo entre o que se é e o que se desejaria ser, entre a realidade vivida e a idealidade almejada, entre uma vida banal e uma vida autêntica.

Num ato de desespero perante o que vê, em tom angustiante, o narrador cita: "É inacreditável! Quase todos se contentam consigo próprios - bastam-se. E vivem, e progridem. Fundam lares. Há quem os beije." (SÁ-CARNEIRO, 1995, p.503.) Temos aqui o deflagrar de mais uma carência: o da realização mundana; o narrador, num momento de profunda agonia, crê que encontraria contentamento numa "vida banal" bem-sucedida, mas que, até mesmo esta, que é concedida à maioria, a ele nunca seria possível, pois "[...] as janelas abertas, sempre... sempre fechadas..." (SÁ-CARNEIRO, 1995, p.504).

O trecho que se inicia após "Paris, 1909 - janeiro 5" faz uma ruptura ao fluxo de consciência que tínhamos até então. O narrador se apresenta agora localizado num tempo e espaço e, enfim, há uma sequência de ações na narrativa.

Hoje encontrei-o pela primeira vez.

Foi no Café. De súbito, vi-o na minha frente... O Café estava cheio. Por isso se veio sentar na minha mesa. [...]

Como é belo!

$\mathrm{E} o$ ar de triunfo que ilumina o seu rosto esguio, macerado?... Tombam-Ihes os cabelos longos aos anéis. É ruivamente loiro. Tive vontade de o morder na boca...

Aquele, sim, aquele é que me saberia ser. (SÁ-CARNEIRO, 1995, p.505)

O texto dá início a uma segunda parte, parte esta em que o "eu" encontra-se com um "outro" - "Hoje encontrei-o" — e, numa espécie de encanto, de mágica, o Outro é descrito exatamente com os atributos que o "eu" não tem, mas que desejaria, pois este Outro é a representação do belo - "Como é belo!". Se não bastasse o fato dele ser belo fisicamente, o outro ainda carrega consigo o "ar do triunfo" aglutinando em si a plenitude de uma beleza de dândi - "rosto esguio", "cabelos longos aos anéis" - associada à sensação de conquista, de glória, de bem-estar. $\mathrm{Na}$ demonstração de um sentimento 
homossexual, o "eu" confessa seu desejo de morder a boca do outro, pois talvez pela conjunção dos corpos este "eu" unido ao "outro" encontrasse uma completude. Encerrando o fragmento, a ideia apontada pelo narrador está na atribuição de sua possível realização na transmutação de si para o outro. Ao não se satisfazer com aquilo que ele reconhece em si, o narrador projeta num outro seu ideal.

São inúmeros os exemplos de questionamentos da identidade apresentados em toda a obra de Mário de Sá-Carneiro e, certamente, um dos textos mais emblemáticos do autor a esse respeito é o poema "7". Composto por uma única quadra, com versos heptassílabos e que faz parte de Indícios de Ouro:

\footnotetext{
Eu não sou eu nem sou o outro, Sou qualquer coisa de intermédio:

Pilar da ponte de tédio

Que vai de mim para o Outro.
}

(SÁ-CARNEIRO, 1995, p.82)

O poema versa sobre a colocação do eu lírico a respeito de quem ele é. Introduzido pelo pronome pessoal do caso reto "eu", contrariamente ao comum num ato de apresentação, ele não vem seguido do verbo de ligação "sou" acrescido de seu predicativo do sujeito, mas do advérbio de negação "não", quebrando a lógica do "eu sou..." por um "eu não sou..." mostrando a certeza de que não se sabe quem se é, e de que, talvez, sua única certeza é ao menos a de não ser determinada coisa. Para aumentar a imprecisão e a estranheza da enunciação da identidade, o eu lírico ainda completa o verso "eu não sou eu". Nesse momento, é demonstrada a contrariedade absoluta, pois o sujeito e seu predicativo apresentam exatamente 0 mesmo significante e o mesmo significado, embora não o sejam.

O eu lírico diz não ser ele próprio e, para piorar a dificuldade de uma possível compreensão, diz também não ser o outro. O reconhecimento de si perde sua condição de comparação com outros seres humanos, ele não é ele próprio, nem tampouco se percebe parecido com "um semelhante". Deste não 
reconhecimento com seus pares numa realidade factual, ele parte para uma busca metafórica que seja capaz de defini-lo. Deste ponto em diante, surge uma possível apresentação de identidade, ainda que esta seja justamente a da dúvida, a do duplo. A expressão "qualquer coisa", que segue ao verbo "ser" é, num processo óbvio de reificação, uma depreciação e o início da delimitação de alguém que pouco acredita valer para algo. O "eu" nada mais é do que "qualquer coisa de intermédio", um ser mediano; nem medíocre - a ponto de despertar a comiseração das pessoas, nem brilhante - a ponto de despertar orgulho.

Ele, ao mostrar-se intermédio, deflagra ser a transparência, a insignificância de "um ser" perante o mundo. Se por um lado ele é um ser mediano em sua colocação de intermédio, por outro é aquele que intermedeia, que se coloca no processo de mediação. Cabe, neste aspecto, se pensar na imagem da ponte, que ele coloca no terceiro verso. Ele se diz o pilar de sustentação desta ponte. Ele é o meio pelo qual é permitida a passagem "que vai de mim para o Outro". Neste momento, o "eu" se mostra grandioso, evidente, ele é o mais alto de todos, pois é o sustentáculo, o pilar de uma ponte, ainda que esta seja do tédio.

O tédio, aqui trazido pela condição de imobilidade da ponte, faz com que este "eu" seja apenas o facilitador na movimentação do "outro" e mostra que ele, individualmente, não é capaz de sair do lugar. A imagem do pilar da ponte, que remete à letra "T", nos aponta para uma ideia de interseccionismo, mas não há uma caracterização mais plausível da identidade do "eu", pois o que há é a reflexão a respeito de quem se seja e a angústia que todas estas dúvidas Ihe causam.

O que caracteriza [...] qualquer coisa no mundo, é, portanto, a sua singularidade, sua unicidade. Esta estrutura fundamental do real, a unicidade, designa ao mesmo tempo o seu valor e sua finitude: toda coisa tem o privilégio de ser apenas uma, o que a valoriza infinitamente, e o inconveniente de ser insubstituível, o que a desvaloriza infinitamente. (ROSSET, 2008, p.83-84) 
A busca por ser único no mundo, por dar ao ser a característica da singularidade, ganha proporções inusitadas na obra carneriana. Fruto de um eterno questionamento "(Que história de Oiro tão bela/ $\mathrm{Na}$ minha vida abortou:/Eu fui herói de novela/Que nenhum autor empregou...)" (SÁCARNEIRO, 1995, p.110) é comum observar as personagens ou os eus em atitudes extremistas e em vozes de um profundo lamento. Como em "Aquele Outro" em que a identificação e o reconhecimento do eu lírico mostram-se repletos de adjetivos depreciativos, através da descrição de uma vida totalmente fora do que o eu pudesse atribuir a um contexto de alegria.

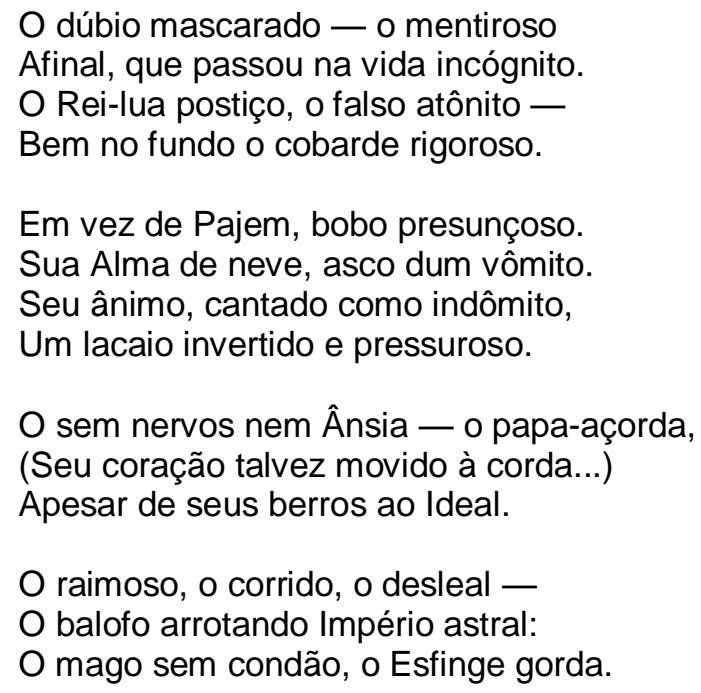

Paris, fevereiro 1916

(SÁ-CARNEIRO, 1995, p.130)

Um ser dúbio, que vive uma farsa, que se percebe como "o mentiroso", que não marcou sua vida em nada, pois por ela passou "incógnito". Para encerrar de maneira cruel a primeira estrofe, ele se diz o "Rei-lua", ou seja, um ser aluado, mas seu aluamento não era por uma condição patológica, mas por ele ser "o cobarde rigoroso". O reconhecimento de si, apontado no poema, é o pior que se possa esperar, nele o eu lírico se diz digno de provocar o "asco dum vômito", compara-se com "o papa-açorda" ${ }^{3}$, seu coração de brinquedo "movido a corda" é seguido de uma série de definições de si mesmo. Na estrofe final,

\footnotetext{
${ }^{3}$ PAPA-AÇORDA s. 2g. 1 maria-vai-com-as-outras, fraco, sem vontade 2 preguiçoso, molenga. (VILLAR, 1989, p.108)
} 
que o deprecia até a última palavra, ele nada mais é que "o Esfinge gorda". Comparar-se a uma esfinge é atribuir a si características "[...] atribuídas as terríveis qualidades dos animais ferozes, juntamente com a sagacidade e outras capacidades humanas." (BULFINCH, 2000, p.150). Ora símbolo da beleza, do feminino perverso, ora sua misteriosa união de homem/animal nada mais é que o símbolo da humilhação e da derrota, como a imposta por Édipo ao solucionar o enigma proposto pela Esfinge e que, desta forma, deixou sua interlocutora "[...] tão humilhada ao ver resolvido o enigma, que se atirou do alto do rochedo e morreu." (BULFINCH, 2000, p.153).

$\mathrm{Na}$ sequência de tantos descontentamentos, as personagens e eus da obra carneiriana não são capazes de se identificarem, de se reconhecerem como indivíduos e, portanto, eles não encontram sua posição no mundo, não se tornam um "ser-no-mundo", propriamente dito por não apresentarem, por exemplo, uma profissão que lhes concedesse um referencial de personalidade. Este desencontro da identificação pode despertar no ser alguns desdobramentos que o levam ao mal: falta de empatia com os demais seres no mundo e uma possível psicopatia pela não transferência para a condição do outro; necessidade exacerbada de liberdade do mundo conservador e opressor, que pode vir pela morte para o encontro com uma individualidade plena; ou, ainda, opção por uma "[...] vida artificial, fictícia, porque a realidade nunca pode ser tão bela quanto a ilusão e porque todo o contato com a realidade, todas as tentativas de concretização de sonhos e desejos levam, necessariamente, à corrupção destes." (HAUSER, 2000, p.912).

\section{3 - As muitas formas de representação do real}

A partir do instante em que o homem se interpela a respeito da questão ontológica, sua tendência natural é deparar-se com um descontentamento. Pressionado a se comparar com o outro a todo instante, em virtude da sociedade massificada em que está inserido, aquilo que o indivíduo reconhece em si fica eternamente insuficiente e a realidade passa a incomodar, tornandose, muitas vezes, intolerável. 
[...] o real só é admitido sob certas condições e apenas até certo ponto: se ele abusa e mostra-se desagradável, a tolerância é suspensa. Uma interrupção de percepção coloca então a consciência a salvo de qualquer espetáculo indesejável. Quanto ao real, se ele insiste e teima em ser percebido, sempre poderá se mostrar em outro lugar. (ROSSET, 2008, p.14)

A impressão passada em muitos momentos da obra de Mário de Sá-Carneiro, em virtude da angústia nela expressa, é a de uma realidade enervante, insuportável, e a saída prevista para o término desta sensação é, sem dúvida, a criação de meios para promover a "interrupção da percepção", citada por Rosset, o escape para o "outro lugar". É na configuração deste escape que o mal ganha espaço para acontecer. A busca por um lugar não real faz com que o indivíduo se sinta livre e à vontade para ter as mais variadas ações: neste lugar, as conexões com o real não mais apresentam o mesmo valor e os mesmos pesos. O homem, nesta instância, "prefere a ilusão perfeita à realidade imperfeita" (HAUSER, 2000, p. 912).

No poema "Partida", que abre Dispersão e que foi datado em 03 de maio de 1913, temos:

Ao ver escoar-se a vida humanamente Em suas águas certas, eu hesito, E detenho-me às vezes na torrente Das coisas geniais em que medito.

Afronta-me um desejo de fugir Ao mistério que é meu e me seduz. Mas logo me triunfo. A sua luz Não há muitos que a saibam refletir.

A minha alma nostálgica de além, Cheia de orgulho, ensombra-se entretanto, Aos meus olhos ungidos sobe um pranto Que tenho a força de sumir também.

Porque eu reajo. A vida, a natureza, Que são para o artista? Coisa alguma. O que devemos é saltar na bruma, Correr no azul à busca da beleza.

É subir, é subir além dos céus Que as nossas almas só acumularam, E prostrados rezar, em sonho, ao Deus 
Que as nossas mãos de auréola lá douraram.

É partir sem temor contra a montanha

Cingidos de quimera e de irreal;

Brandir a espada fulva e medieval,

A cada hora acastelando em Espanha.

É suscitar cores endoidecidas,

Ser garra imperial enclavinhada,

E numa extrema-unção d'alma ampliada,

Viajar outros sentidos, outras vidas.

Ser coluna de fumo, astro perdido,

Forçar os turbilhões aladamente,

Ser ramo de palmeira, água nascente

$\mathrm{E}$ arco de ouro e chama distendido...

Asa longínqua a sacudir loucura,

Nuvem precoce de subtil vapor,

Ânsia revolta de mistério e olor,

Sombra, vertigem, ascensão - Altura!

E eu dou-me todo neste fim de tarde

À espira aérea que me eleva aos cumes.

Doido de esfinges o horizonte arde,

Mas fico ileso entre clarões e gumes!...

Miragem roxa de nimbado encanto -

Sinto os meus olhos a volver-se em espaço!

Alastro, venço, chego e ultrapasso;

Sou labirinto, sou licorne e acanto.

Sei a distância, compreendo o Ar;

Sou chuva de ouro e sou espasmo de luz;

Sou taça de cristal lançada ao mar,

Diadema e timbre, elmo real e cruz...

O bando das quimeras longe assoma...

Que apoteose imensa pelos céus!

A cor já não é cor — é som e aroma!

Vêm-me saudades de ter sido Deus...

Ao triunfo maior, avante, pois!

O meu destino é outro - é alto e é raro.

Unicamente custa muito caro:

A tristeza de nunca sermos dois...

(SÁ-CARNEIRO, 1995, p.55-56)

Nas quatorze quadras decassílabas do poema, temos um eu lírico que descreve seus apontamentos quanto a sua existência e sua condição de poeta. 
"Partida" foi a escolha de Sá-Carneiro para abrir o livro Dispersão e a adequação da escolha se dá muito pelas pistas que ele apresenta, tanto sobre a evasão da realidade, que é fundamental na obra do autor, quanto sobre o tratamento dado à arte e à questão ontológica que nela se apresenta.

Nas quatro quadras iniciais, presenciamos os apontamentos do eu sobre a realidade em que ele se vê inserido e o deslocamento possível para a idealidade que sua condição de artista é capaz de o alçar. Ao ver sua vida não ser vivida, mas sim "escoada", tem-se o tom do pessimismo existencial mostrado pelo eu sobre a realidade em que está inserido.

Arrebatado pelo tédio de sua vida "em águas certas" é que o eu vê-se tomado pela angústia e pela consciência de sua condição de "ser", fazendo-o divagar e se entregar às "coisas geniais em que medito". Suas reflexões despertam "um desejo de fugir/Ao mistério que é meu e me seduz". Transportado, seduzido a uma realidade paralela, mas que a ele pertence, o eu aponta sua condição de escolhido, de selecionado "A sua luz/Não há muitos que saibam refletir." Se, na sua percepção de realidade do mundo factual, ele não representa muita coisa, na idealidade por ele criada, ele é o "ungido".

O jogo de sedução instaurado entre o ficar "Porque eu reajo" e o entregar-se "logo me triunfo" indicam a cisão que o eu apresenta. Seus versos da quarta estrofe referem-se a um eu lírico que despreza a vida e a natureza, pois estas, para o eu, na condição de artista, valem "Coisa alguma." Segundo Woll "A esfera da realidade está esboçada [...] através de duas palavras - "vida" e "natureza"." (1968, p.53). Associar vida e natureza ao universo dos poetas decadentes em que Mário de Sá-Carneiro está inserido mostra uma repulsa à primeira, pois nada que seja natural é visto com bons olhos pelos mesmos, como aponta Théophile Gautier em seu prefácio para As flores do mal, de Charles Baudelaire: "Tudo o que afastava o homem e especialmente a mulher do estado natural parecia-Ihe uma invenção feliz." (In: MORETTO, 1989, p.49).

"A vida humanamente" que é expressa pelo poeta, é sinônimo da ideia heideggeriana de "vida banal". Ele aponta em seus versos, sua percepção do 
que ele nota como real (águas certas) e o espaço de idealidade para onde se move (torrente), formando uma oposição entre o real (monótono, calmo) e o ideal (frenético, movimentado). Tomado por um "desejo de fugir" ele se diz entregue àquilo que o seduz e pertence: o mistério.

Da quinta à nona estrofes, há uma mudança no foco do poema. Se antes tínhamos um eu que se colocava em primeira pessoa "eu hesito", agora temos um eu que se manifesta no plural "Que as nossas almas só acumularam". A cisão homem/artista aqui se perde e dá lugar ao ideal artístico "É subir, é subir além dos céus". A troca da primeira para a terceira pessoa é a transposição do mundo do eu, para um outro mundo. É a transcendência do mundo individual para o mundo das quimeras ilimitadas do artista que passa a se manifestar.

Com imagens de ascensão, o eu indica a grandeza do poeta e sua condição de criador, o demiurgo capaz de criar até mesmo o "Deus/que as nossas mãos de auréola lá douraram". Na sequência, metáforas dão as referências de um real criado "Cingidos de quimera e de irreal", em que se é capaz de ter "cores endoidecidas", "ser garra imperial enclavinhada", "viajar outros sentidos, outras vidas". A nona estrofe se encerra com a imagem de uma "Asa longínqua" que finda em "Sombra, vertigem, ascensão - Altura!".

O otimismo se interrompe com o início da décima estrofe e é retomado o uso da primeira pessoa "eu dou-me". O ser dúbio, em agonia, se identifica como "Sou labirinto, sou licorne e acanto.". A imagem do labirinto aponta a complexa construção ôntica, que se dá àquele que ao se analisar percebe uma quantidade de veredas que não dão a indicação para a saída. Quanto mais se investiga, mais se perde em suas entranhas. O ser labiríntico, que se dá à consciência do questionamento, tem como resposta os ambíguos e contraditórios substantivos "licorne" e "acalanto". Ora um licorne, animal mitológico que, segundo Brunel (2005), dentre os muitos significados que carrega durante a história, é um animal solitário e cruel, cujo chifre no meio da testa imprime a estranheza e que associa o masculino e o feminino em si. Ora acalanto, planta ornamental, espinhosa, de flores roxas e bastante comum na decoração da arquitetura gótica, de caráter misterioso e sobrenatural. $\mathrm{O}$ 
caminho para se chegar a si é labirinto e nele o natural e o artificial, o bem e o mal caminham lado a lado.

A sequência de imagens que vem em seguida apresenta o ser demiurgo que tudo sabe "Sei a distância, compreendo o Ar", que tudo compreende e que aponta para uma apoteose. A deificação que o artista é capaz de promover recua perante a inelutável "tristeza de nunca sermos dois...". O conflito entre um eu que está posto no mundo real e precisa se adequar às necessidades que este mundo the impõe, com suas condições de "rotinidade", como mostra Heidegger, contra um eu demiurgo, artista, que clama por uma vida autêntica e livre são a tônica de uma poética que versa sobre a possibilidade de se ter uma vida comum e uma vida artística; ou, ainda, a ideia fixa, na obra carneiriana, de criar, projetar um duplo que ofereça a realização de ser dois.

A realidade apresentada no poema "Partida" suscita a discussão da inabilidade do eu lírico de viver uma vida chamada de real e sua busca por um escapismo pela arte, pela alteridade, pelo mistério, pelo duplo, que podem significar o encontro de uma vida que sacie sua angústia, vinda da eterna consciência do mundo em que vive e de si. A criação de uma nova realidade é o deslocamento necessário para a realização de uma vida tolerável, uma vida que corre paralela à vida real e que na literatura de Sá-Carneiro também se manifesta numa fuga pela ilusão de felicidade vivida em locais idealizados, como Paris, por exemplo. Escapismos que viabilizam a realização de tantas quantas ações forem desejadas sem a presença de censuras, em que todos os desejos sejam possíveis e realizáveis.

\section{4 - Do desalento pelo espaço português a outros espaços}

Segundo Eduardo Lourenço, a saída de Portugal em busca das grandes navegações pode ser considerada como uma loucura, mas é graças a ela que houve uma descentração da Europa. E foi graças a ela também que Portugal se colocou ao lado das nações mais ricas e poderosas da época. O autor também considera que esta: 
Descentração que marcou durante séculos - e marcará talvez para sempre - aquilo que somos enquanto povo exclusivamente europeu. A quatro séculos de distância, dois dos nossos maiores poetas, Camões e Pessoa, exprimiram melhor do que ninguém essa descentração, simultaneamente real e simbólica, que nos caracteriza no conjunto dos povos do Ocidente europeu. (LOURENÇO, 2001, p.57)

A visão que o português apresenta de seu país se mostra muito fundamentada no passado de glórias marítimas. Camões e Pessoa, como bem citou Lourenço, imortalizaram suas terras em dois dos maiores poemas da literatura lusófona, escrevendo Os lusíadas e Mensagem, respectivamente. Mas o mesmo país que viu:

Com D. Manuel, o Venturoso [...] uma grande nação; com D. Sebastião, conhece o início da derrocada. [...] Portugal passa para o domínio espanhol em 1580. Sessenta anos depois, ao recuperar sua independência política, o país é mero arremedo do que conseguira ser durante dois séculos: o XV e o XVI. (VECHI, 2003, p.86)

De uma das maiores potências mundiais, perceber-se um arremedo, completamente rebaixado a um pedaço pequeno da Península Ibérica, sem grande representação no contexto mundial, despertou no português "[...] uma mistura inextricável de autoglorificação e de profundo sentimento de decadência e de saudade." (LOURENÇO, 2001, p.58).

Desfeito o sonho de "autoglorificação" e tomado pelo "sentimento de decadência", Portugal ganhou um ar de realidade que se tornara insuportável para Sá-Carneiro, e isso fez com que ele se entregasse a escrever uma obra repleta de desesperança com sua pátria e cheia de saudosismo. Em seu processo de escrita, o autor não nega a presença portuguesa e sua desinteressante realidade. Ele apenas desloca sua obra para um mundo de ilusão. "Na ilusão, quer dizer, na forma mais corrente de afastamento do real, não se observa uma recusa da percepção propriamente dita. Nela, a coisa não é negada: mas apenas deslocada, colocada em outro lugar." (ROSSET, 2008, p.21). Na obra de Mário de Sá-Carneiro, coube a Portugal ser o lugar da 
representação do cotidiano, com suas burocracias e falta de charme; é o lugar onde se abriga toda a vida sem graça, desinteressante e banal que a realidade dos homens, ditos comuns, insiste em estabelecer.

No poema "O Lord", publicado em Indícios de Ouro, temos:

\author{
Lord que eu fui de Escócias doutra vida \\ Hoje arrasta por esta a sua decadência, \\ Sem brilho e equipagens. \\ Milord reduzido a viver de imagens, \\ Para às montras de joias de opulência \\ Num desejo brumoso — em dúvida iludida... \\ (- Por isso a minha raiva mal contida, \\ - Por isso a minha eterna impaciência.) \\ Olha as Praças, rodeia-as... \\ Quem sabe se ele outrora \\ Teve Praças, como esta, e palácios e colunas - \\ Longas terras, quintas cheias, \\ lates pelo mar fora, \\ Montanhas e lagos, florestas e dunas... \\ (- Por isso a sensação em mim fincada há tanto \\ Dum grande patrimônio algures haver perdido; \\ Por isso o meu desejo astral de luxo desmedido - \\ E a Cor na minha Obra o que ficou do encanto...)
}

Paris, setembro de 1915

(SÁ-CARNEIRO, 1995, p.113)

O poema versa sobre as lembranças de um tempo perdido, representado pelas "Escócias doutra vida" que, contrariamente ao desejado, não voltam mais e que se opõem ao que hoje ele descreve como dotado de uma "decadência, sem brilho e equipagens." Presente e passado em plena oposição são representados pela contradição daquilo que se é com aquilo que se foi. Um dia, "Lord"; hoje, decadente, um "Milord" que nada pode além de parar para admirar "montras de joias de opulência". O passado glorioso de outro tempo não apenas Ihe foi tirado, mas também o maltrata por tê-lo feito ter acesso àquilo que de melhor se pudesse ter e, hoje, o eu lírico percebe-se sofredor por sua privação.

As estrofes, todas irregulares (uma oitava, uma sextilha e uma quadra), com versos quase livres, aproximam-se da temática do poema, pois o eu se mostra 
desordenado e confuso, misturando uma "raiva mal contida" com uma "eterna impaciência". As demonstrações claras de raiva por ter sido "reduzido a viver de imagens", mostram que tudo que the restou foram as lembranças de um tempo glorioso, mas hoje perdido. Cabe ao hoje, nesta perspectiva, representar Portugal como descreveu Lourenço (2001), após seus tempos de glória, num momento de "decadência e saudade". O "desejo brumoso" nesta estrofe apontada é referência ao sebastianismo, ele se lamenta pela "dúvida iludida". Muito possivelmente, o fato de D. Sebastião ter seu desaparecimento não esclarecido, sem um desfecho completamente plausível, é bastante inquietante, pois não permite um verdadeiro encerramento de seu ciclo. É a esperança que se eterniza e que não permite a vinda do novo. O poema marca - sebastianismo tão presente na literatura portuguesa, deflagrando o sentimento de esperança de um possível retorno dos tempos memoráveis.

Esbravejando em inquietação, o eu lírico justifica sua raiva e sua impaciência pela vida de glórias que não voltam mais, "(- Por isso a minha raiva mal contida,/ - Por isso a minha eterna impaciência.)". Chamando pelo interlocutor, o eu lírico inicia a segunda estrofe com imperativos "Olha as Praças" e questionamentos, "Quem sabe se ele outrora/Teve Praças, como esta, e palácios e colunas -", apontando alguns lugares (como praças, palácios, colunas, iates, quintas) que, um dia, foram representativos de um tempo de opulência e glória, dando abertura para a terceira estrofe, que marca uma esperança de "algures" ter esse grande patrimônio retomado numa reversão do sentido nacionalista apresentado até então no poema que, no caso do eu lírico, se realiza na composição de sua "Obra". Obra esta que está repleta de "Cor" e de "um desejo astral de luxo".

O poema imagético, com vocabulário precioso, representa os tempos gloriosos portugueses e, sendo assim, é uma maneira de revivê-los. É na arte que os bons tempos podem ser revisitados, que as glórias podem ser reexperimentadas, ainda que seja sabido que a literatura é uma forma de representação, uma possibilidade de expressão de um fato, mas não é o fato em si. 
Utilizando-se de referências do Reino Unido, "O Lord" deflagra um desalento pelo tempo presente, marcadamente representado por Portugal; e um saudosismo de um passado glorioso, sendo arrefecido pela fuga a países estrangeiros, fora de Portugal. O eu lírico enumera, na segunda estrofe, todas as semelhanças do lugar de onde ele fala, para com o outro onde ele não está. As "longas terras, quintas cheias,/lates pelo mar afora" tudo acabado, tudo findado. O lugar da lembrança é apenas motivo de decepção e de reforço, de como um dia já fora maravilhoso.

Os espaços Portugal/Estrangeiro ganham, nesta dimensão, a ideia de que um representa o espaço da vivência e o outro o espaço do desejo. Inglaterra, Escócia e Rússia ganham abrigo em textos carneirianos e sua arquitetura, ambientação e representação de liberdade e autonomia são apontadas como acolhedoras e vistas positivamente, mas nenhum país tem a dimensão e importância que a França e sua capital, Paris, dentro do conjunto de textos do autor. Em contraposição com Portugal, a capital francesa é uma marca dentro da poética, uma vez que ela personifica a beleza, a sofisticação, a ambiência artística, a liberdade e o luxo. É em Paris que o ser da poética carneiriana encontra o espaço adequado para viver a fuga da vida banal, representada por Portugal, e encontra campo fértil para a consagração de uma vida livre para ser experimentada em todas as suas possibilidades.

Poderia ser apenas mais um poema, entre tantos que foram escritos fazendo referência à capital francesa, mas não é apenas isso. "Nossa Senhora de Paris" é a chave para se entender o valor e a função dada por Mário de SáCarneiro à Catedral parisiense - também lembrada e descrita detalhadamente em "Asas", de Céu em fogo. É um poema que retrata a devoção e a admiração do poeta pela cidade luz, que em muito representava os delírios de liberdade e desprendimento tão sufocados na realidade portuguesa. Paris é a representação do espaço ideal para os mais íntimos desejos serem realizados, ela é a grande capital, com sua população imensa, que concede ao homem comum a garantia do anonimato. Nela estão cafés, restaurantes e os bulevares, repletos de espaço para o passeio público. Utilizando-se da figura de Charles Baudelaire para exemplificar seus estudos, Benjamin aponta que: 
Era no bulevar que ele tinha à disposição o primeiro incidente, chiste ou boato. No bulevar, desdobrava os ornamentos de suas relações com colegas e boas-vidas; e estava tão dependente de seus efeitos quanto as coquetes de sua arte de se transvestir. No bulevar, passava suas horas ociosas, exibindo-as às pessoas como parcela de seu horário de trabalho. (BENJAMIN, 1989, p.24-25)

Paris é a representação da modernidade com seus bulevares, com a boemia permitida e valorizada. Neste espaço não cabe a rotina, um mundo novo pode ser desbravado a cada dia na certeza do anonimato, "[...] a massa desponta como o asilo que protege o antissocial contra os seus perseguidores." (BENJAMIN, 1989, p.38).

Listas de som avançam para mim a fustigar-me

Em luz.

Todo a vibrar, quero fugir... Onde acoitar-me?...

Os braços duma cruz

Anseiam-se-me, e eu fujo também ao luar...

Um cheiro a maresia

Vem-me refrescar,

Longínqua melodia

Toda saudosa a Mar...

Mirtos e tamarindos

Odoram a lonjura;

Resvalam sonhos lindos...

Mas o Oiro não perdura

E a noite cresce agora a desabar catedrais...

Fico sepulto sob círios -

Escureço-me em delírios,

Mas ressurjo de Ideais...

- Os meus sentidos a escoarem-se...

Altares e velas...

Orgulho... Estrelas...

Vitrais! Vitrais!

Flores-de-lis...

Manchas de cor a ogivarem-se...

As grandes naves a sagrarem-se...

- Nossa Senhora de Paris!... 
Segundo poema de Indícios de Oiro, com versos livres e rimas variadas, "Nossa Senhora de Paris" é um poema imagético, pois apresenta descrições do espaço da catedral, como um objeto estético, digno de ser cantado em versos.

A primeira estrofe nos apresenta um eu lírico observando a catedral internamente e seu foco está nos vitrais da nave central. A luz bate em seus olhos e, num processo sinestésico, som e luz se mesclam e "das listas de som" ele se vê fustigado "Em luz". As interferências agressivas de luz e som em seu corpo fazem com que ele possa vibrar e é esta vibração que o transporta para um mundo alternativo. O eu lírico, tomado pelas sensações, se descola da realidade e passa a se entregar a um sonho, a um mundo paralelo.

A mistura das sensações se intensifica na segunda estrofe, que evoca o "Mar". O eu se diz atraído por "um cheiro de maresia", que o refresca e ainda, neste instante, é capaz de fazê-lo ouvir "Longínqua melodia". Frutos e flores embalam "sonhos lindos". A imagem do mar, carregada dos seus significados de grandeza, de horizontes infindáveis, de bem-estar, está tão forte que é capaz de fazê-lo perceber até mesmo o "cheiro da maresia", prova da entrega absoluta do eu lírico para esta nova realidade em que está vivendo. O mar, que sempre foi um motivo de orgulho dos feitos portugueses, lembrança das glórias das grandes navegações, foi também produtor de um conforto oriundo de tempos que não voltam mais. A memória de um tempo perdido faz com que o eu se desligue, por completo, de sua realidade presente e se entregue a um sonho, um devaneio de seus próprios pensamentos.

A rejeição automática do presente no passado ou no futuro é, geralmente, a ação de um indivíduo que não pensa que outra coisa venha monopolizar sua atenção, mas está, ao contrário, fascinado pela própria coisa, presente, da qual tenta desesperadamente se desligar, e só consegue isso relegando-a, como por magia, para um passado ou para um futuro próximo, pouco importa onde ou quando, contanto que a coisa não seja mais no presente nem aqui [...]. (ROSSET, 2008, p.67) 
É exatamente esse o processo que o eu de "Nossa Senhora de Paris" passa. O eu, adentrado num processo de negação de tudo que o pudesse tirar desta dimensão, com seu olhar altamente aprimorado e repleto de devaneios, faz com que ele "em delírios" ressurja "de Ideais...". Tal qual o homem da caverna platônico, o eu custa a se acostumar com a luminosidade, mas depois da acomodação de seu olhar, esta se mostra sublime e absolutamente sedutora para ele. A catedral não mais existe sob o ponto de vista da construção ou da sua funcionalidade religiosa, ou turística ou outra qualquer, mas, a partir de então, ela ganha uma dimensão de magia, de transcendência. É como se, a partir daquele instante, a catedral se tornasse a nau que levava o eu ao sonho, ao ideal, ao inexplorado, ao mistério. Estar em Paris e ser capaz de perceber a beleza da luz são o passaporte para a dimensão do sublime, para o entendimento de outros mundos, ainda que, assim como o homem da caverna, o ônus seja o da incompreensão, da incredulidade e, muitas vezes, da hostilidade para com aqueles que verdadeiramente veem.

Com "Os meus sentidos a escoarem-se..." ele passa a ver os detalhes da igreja, as "Flores-de-lis...", "Altares e velas", as imagens se misturam ao sentimento despertado neste instante. A catedral termina sendo cantada como "As grandes naves a sagrarem-se..."; na plurissignificação da palavra "nave" temos a mistura do real e do sonho. Ora o templo religioso, ora a nau que transporta o eu para uma nova realidade. A igreja abriga o ideal de lugar que se manifestará em muitos momentos da obra carneiriana, seus versos livres ressoam como o desejo de liberdade que só Paris era capaz de carregar no início do século XX. Segundo Hauser, a Paris desta época é:

[...] a capital da Europa, não, porém, como antes, o centro da arte e da cultura, mas a metrópole do mundo e da diversão, a cidade da ópera, da opereta, do balé, dos bulevares, restaurantes, das lojas de departamentos, das exposições universais e dos prazeres baratos e prontos para o consumo. (HAUSER, 2000, p.789)

O nome da igreja Nossa Senhora de Paris é, como muitas outras igrejas francesas, a homenagem e representação da santa a que ela carrega em seu 
interior, unida ao local de sua construção. Maria, a mãe de Jesus, que está representada por sua imagem na nave central da igreja, é a grande senhora, a figura máxima de devoção e idolatria do cristão francês, bem como a cidade o era para os artistas de toda a Europa da época. Paris deixa de ser apenas uma cidade, um espaço urbano, um lugar qualquer para ganhar a condição daquilo que Marc Augé chama de "lugar antropológico".

[...] é o lugar do sentido inscrito e simbolizado, o lugar antropológico. [...] incluímos na noção de lugar antropológico a possibilidade dos percursos que nele se efetuam, dos discursos que nele se pronunciam e da linguagem que o caracteriza. (AUGÉ, 2010, p.76-77)

Ricardo de Loureiro, de A confissão de Lúcio, descreve Paris exatamente com a proporção apontada por Augé:

\begin{abstract}
Entretanto, Lúcio, não creia que eu ame esta grande terra pelos seus bulevares, pelos seus cafés, pelas suas atrizes, pelos seus monumentos. Não! Não! Seria mesquinho. Amo-a por qualquer outra coisa: por sua auréola, talvez, que a envolve e a constitui em alma - mas que eu não vejo; que eu sinto que eu realmente sinto e não Ihe sei explicar!... (SÁ-CARNEIRO, 1995, p.370)
\end{abstract}

Ele não vê a cidade por suas edificações, atrações e passeios, pelos "seus bulevares, pelos seus cafés, pelas suas atrizes, pelos seus monumentos”, mas sim, por aquilo que a cidade desperta nele, aquilo que ele chama de "alma", "auréola". Pela subjetividade demonstrada, ele finaliza dizendo apenas ser capaz de sentir a cidade e de que não sabe explicá-la, pois ele não mais se apresenta na cidade real, ele já está na dimensão antropológica.

A conquista deste "espaço antropológico" que, neste caso, é Paris, ganha uma dimensão que "envolve e constitui em alma" e que, provavelmente, não corresponde à ideia tida para a mesma cidade, se vista por um de seus moradores locais. Será que a mesma Paris era vista com tamanha grandeza 
pelo cidadão parisiense comum? Alguns dos textos de Charles Baudelaire nos fariam crer que não, como podemos perceber em "À uma hora da manhã":

\begin{abstract}
Enfim, só! Ouve-se apenas o rolar das rodas dos fiacres atrasados e alquebrados. Durante algumas horas nós possuiremos o silêncio, senão o repouso. Enfim a tirania da face humana desapareceu e só sofrerei por mim mesmo.

Enfim! É-me permitido, então, relaxar no banho das trevas. De saída, uma dupla volta na chave aumentará minha solidão e fortificará as barricadas que me separam atualmente do mundo. Horrível vida! Horrível cidade! (BAUDELAIRE, 2006, p.57)
\end{abstract}

A Paris por ele citada em nada nos lembra a maravilha carneiriana contada efusivamente por Ricardo.

Como eu amo as suas ruas, as suas praças, as suas avenidas! Ao recordá-las longe delas - em miragem nimbada, todas me surgem num resvalamento arqueado que traspassa em luz. E o meu próprio corpo, que elas vararam, as acompanha em seu rodopio. (SÁ-CARNEIRO, 1995, p.370)

Enquanto um diz "Como eu amo" (SÁ-CARNEIRO, 1995, p.370), o outro proclama "Horrível cidade!" (BAUDELAIRE, 2006, p.57). Isto muito provavelmente está associado ao fato de que o narrador de Baudelaire era um cidadão parisiense e de que trazia a ideia do tédio, da rotina que o envolvia com a cidade atrelada a ele pois, segundo Augé, se um espaço já se mostra conquistado, familiar ou ainda pior que isso, natural, ele passa a perder seu sentido e fica bastante possível que nada represente, a não ser um tédio absoluto. A cidade conquistada representa o real, a cidade imaginada representa o ideal. O espaço passa, então, a ser revisto e o sentimento de tédio desta conquista só poderá ser superado pela busca de um novo desafio com um novo espaço, mas, para não correr o risco de se entediar novamente, este espaço deve ganhar o valor do "espaço antropológico", um espaço cujo valor está muito associado à sua representação e simbologia e não a uma realidade propriamente dita. Segundo Schopenhauer (2005), o novo é uma eterna reivindicação, uma busca diária e constante e, se por um lado este 
espírito novidadeiro poderia representar a fuga do tédio, a conquista desperta uma incômoda sensação de descontentamento contínuo, uma fonte de eterna angústia, que é o que acontece toda vez que o ser humano conquista seu objetivo.

Num determinado momento da história da humanidade, o reconhecimento do homem - ou aquilo a que ele dava o nome de identidade — estava muitíssimo ligado ao que ele fazia e se mostrava do ponto de vista social. A pessoa era reconhecida, por exemplo, pelo seu ofício ou cargo, como um padre, um sapateiro ou o que exercesse. O espaço, nesta perspectiva, era capaz de gerar identidade, relações e histórias. À medida que temos no universo dos textos carneirianos personagens/eus que não apresentam nenhum ofício que não seja o labor artístico, o espaço português, que não se mostrava tão propício a isso, fica realmente sem grande interesse e função para esses seres. O olhar deles é despertado, nesta dimensão, para onde a arte sempre teve seu glamour reconhecido e valorizado. O espaço parisiense ganha lugar de destaque, uma vez que nele não era preciso a presença dos compromissos diários, da aceitação de um ofício, nele seria possível viver uma vida como artista, numa eterna busca por experiências sempre novas e surpreendentes.

Portugal é o lugar que desperta o desinteresse, pois guarda em si um recalque. Em A confissão de Lúcio, a cidade de Lisboa é lembrada por su"As ruas tristonhas de Lisboa do Sul" em que o narrador "[...] descia-as às tardes magoadas rezando o teu nome: O meu Paris... o meu Paris..." (SÁ-CARNEIRO, 1995, p.371). A evidência de que Paris era o local ideal para o narrador fica evidente no desabafo posto na voz de Ricardo de Loureiro. E, quando ele exclui Lisboa da Europa, alegando que a cidade em nada combinava com a civilidade e alegria que ele desejava para a vida, denota a falta de progresso português.

Ricardo não escondia de ninguém sua incapacidade de aceitar viver em Portugal. Seu desejo de morada era assim descrito por ele: 
Só posso viver nos grandes meios. Quero tanto ao progresso, à civilização, ao movimento citadino, à atividade febril contemporânea!...

Europa! Europa! Encapela-te dentro de mim, alastra-me da tua vibração, unge-me da minha época! (SÁ-CARNEIRO, 1995, p. 370)

Ávido por "Europa!", o seu desejo era da grandeza da civilização, de um artista que sentia a gana de ter a liberdade citadina que 0 atraso e a religião exacerbada portuguesa nunca the permitiriam. Novamente, usando de uma imagem sagrada, como em "Nossa Senhora de Paris", ele pede para ser encapelado, vibrante e ungido pela sua Paris, a mesma que ganha a condição de nau que transporta ao ideal. Com sua magnitude, ela ganha ares de totalidade, de sublime e de grandiosidade. Seus espaços, como um simples restaurante, ganham uma proporção que não seria a esperada numa situação normal, pois aquele local que era apenas para saciar ou servir de passeio comum apresenta uma propulsão de sentimentos nunca antes vividos e manifestados.

Tive sempre muito afeto ao célebre restaurante. Não sei... o seu cenário literário (porque o lemos nas novelas), a grande sala de tapete vermelho e, ao fundo, a escadaria; as árvores românticas que exteriormente o ensombram, o pequeno lago - tudo isso, naquela atmosfera de grande vida, me evocava por uma saudade longínqua, sutil, bruxuleante, a recordação astral de certa aventura amorosa que eu nunca tivera. Luar de outono, folhas secas, beijos e champanhe... (SÁ-CARNEIRO, 1995, p. 376)

O restaurante desperta na personagem uma "atmosfera de grande vida", o que nos faz crer que tudo que vivera anteriormente nada representou. Descrito como um ambiente com "árvores românticas" que geram uma sombra no espaço de luzes sutis e intermitentes, lá ele era capaz de sentir até mesmo a saudade de um amor nunca vivido.

A admiração de Lúcio (cujo nome é semelhante ao da "Cidade Luz") igualmente era partilhada por Ricardo, que não se esquivava de fazer as mais sinceras declarações a respeito de um Paris (sempre tratado no masculino) "- 
Paris! Paris! - exclamava o poeta. - Por que o amo eu tanto?" (SÁCARNEIRO, 1995, p. 370) com suas ruas e praças e avenidas charmosas.

Não sei... Basta lembrar-me que existo na capital latina, para uma onda de orgulho, de júbilo e ascensão se encapelar dentro de mim. É o único ópio louro para minha dor - Paris!

Como eu amo as suas ruas, as suas praças, as suas avenidas! Ao recordá-las longe delas - em miragem nimbada, todas me surgem num resvalamento arqueado que me traspassa em luz. E o meu próprio corpo, que elas vararam, as acompanha no meu rodopio. (SÁ-CARNEIRO, 1995, p. 370)

"Tudo nele me é heráldico, me é litúrgico [...]." (SÁ-CARNEIRO, 1995, p. 370) "Heráldico" e "litúrgico" são dois adjetivos que sagram e definem bem o papel de Paris como aquela que acolhe como templo e que possibilita o encontro com o sublime, com o sagrado. A cidade, por toda obra de Sá-Carneiro, é mostrada com a nobreza associada a uma espécie de cerimonial. Em Paris, tudo lembra a uma liturgia que envolve festas, conversas intelectualizadas, idas a teatros, óperas e todas as faces que a noite sofisticada era capaz de oferecer como ritual. Ela, na sua dimensão antropológica, em que o real e o ideal se mesclam, cuja noção de um ou de outro não são exatamente possíveis de se detectar aos olhos humanos, carrega a ambiguidade e a ilusão pintadas por Magritte em "Os sinais da noite". O efeito da dupla visão nos transporta por um mundo de infinitas possibilidades, em que uma cena adentra a outra e não se é capaz de detectar se foi a figura esférica que deslizou do quadro menor e se alocou no maior ou se ela sempre esteve ali. 


\section{CAPÍTULO 2 - ALGUMAS FACES DO MISTÉRIO}

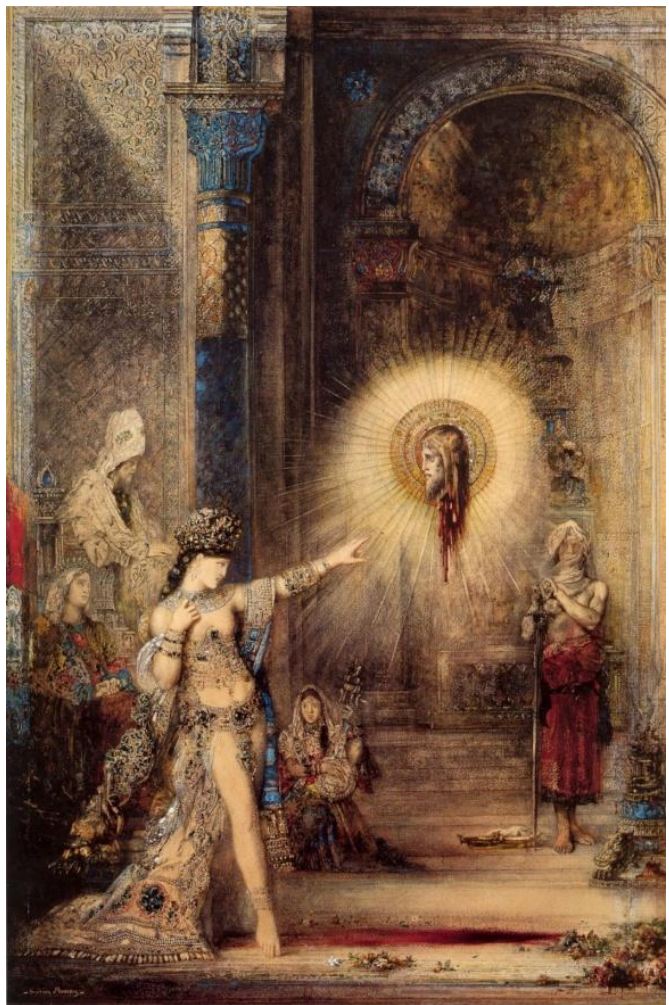

MOREAU, Gustave. Salomé dança para Herodes.

"Essas brincadeiras nerwasas nãa sãa isentas de periga, e pade-se às vezes pagar cara par elas. Mas a que imparta a eternidade da danaçãa a quem encantrau num segunda a infinita da fruiçãa?"

Charles Baudelaire, Pequenas paemas em prasa. 


\section{1 - 0 mistério}

O livro Céu em Fogo, escrito entre os anos de 1913 e 1914, em Paris, Lisboa e na Quinta da Vitória, é composto por oito narrativas. Publicado em 1915, a obra teve seu nome retirado de outra obra de Mário de Sá-Carneiro, Princípio, em que uma personagem dá esse título a um livro seu. Suas nove ${ }^{4}$ narrativas são compostas por um dos grandes temas carneirianos: o mistério. Em "A grande sombra", Mário de Sá-Carneiro explicita, através de uma personagem, que "[...] todo o meu desejo é de emprestar um pouco de enigma a essa vida banal, pequenina..." (SÁ-CARNEIRO, 1995, p.426).

Segundo Maria da Graça Carpinteiro, a obra do autor está repleta de "[...] novelas em que o mundo real estoura por todos os lados e onde a vida inteira obedece a uma lei inexorável: aquilo a que à falta de designação mais precisa se convencionou chamar Mistério." (1960, p.17-18). A palavra/tema aparece em muitos textos: "Ao mistério que é meu e me seduz." do poema "Partida" (SÁ-CARNEIRO, 1995, p.55); "Sou esfinge sem mistério no poente." do poema "Estátua falsa" (SÁ-CARNEIRO, 1995, p.64); "Mistério é riqueza —/E o medo é Mistério!..." do poema "Não", (SÁ-CARNEIRO, 1995, p.78) ou ainda "Mistério duma incerteza/Que nunca se há-de fixar.../Sonhador em frente ao mar/Duma olvidada riqueza..." do poema "Sete canções de declínio" (SÁ-CARNEIRO, 1995, p.101), dentre inúmeros outros.

A palavra "mistério" apresenta muitas significações. Segundo o Dicionário Houaiss da Língua Portuguesa:

1. HIST. REL. culto secreto, ao qual não eram admitidos senão os iniciados. 2. p. ext. algo que é secreto, escondido, não repartido com os outros; segredo [...] 8. HIST. TEAT. tipo de drama medieval caracterizado pela encenação dos mistérios que envolviam os sacramentos ou pela dramatização de certas passagens da Bíblia. (HOUAISS, 2004, p.1935)

\footnotetext{
${ }^{4} \mathrm{Na}$ edição portuguesa, publicada pela Europa-América, são apenas oito contos, pois "Além e Bailado" não consta.
} 
Já o verbete no E-Dicionário de Termos Literários é descrito por José António Serra como "1. a mais significativa forma de drama sacro na Idade Média. 2. um tipo de ficção." (SERRA, "mistério"). Como texto medieval, suas características estavam:

[...] na representação, sob forma de espetáculo teatral, de histórias e episódios da vida de Cristo, baseados fundamentalmente no Novo Testamento e nas tradições e lendas com este associadas, bem como nas partes do Antigo Testamento que, de alguma forma, eram consideradas prefigurações daquele. [...] Nestas peças, os elementos espetaculares dominam sempre os elementos literários e o estilo dramático. (SERRA, "mistério")

Como gênero:

[...] um tipo de ficção com vários subgêneros, que vão desde o romance policial até ao romance gótico.

Todos estes tipos de ficção abordam um crime e a sua resolução. O suspense geralmente está presente no caminho para a solução, que coloca em perigo o detetive ou os que perseguem o vilão, colocando vítimas inocentes em perigo.

As fronteiras do moral e do imoral, da ordem e da anarquia, com as quais se ocupam as histórias de mistério, podem encontrar-se nas tragédias clássicas e no teatro shakespeariano, notavelmente obcecado com o crime terrível e a psicologia criminal. (SERRA, "mistério")

A união destas acepções é que forma a ideia de mistério escrita por Mário de Sá-Carneiro. O mistério tanto é o enigma, ou seja, tudo aquilo que não é feito às claras, que não se apresenta objetivamente; como é um culto religioso secreto que só pode ser frequentado pelos seus iniciados; ou, ainda, é um gênero narrativo que privilegia o suspense e o crime e cujas "fronteiras do moral e do imoral" não são possíveis de serem detectadas.

É nesta seara que foi escrito Céu em Fogo, que tem sua epígrafe retirada de $\mathbf{O}$ idiota, de Fiódor Dostoievski, e ela em muito nos diz sobre a temática do livro, pois associa termos aparentemente contraditórios que, unidos, criam uma ambiência de estranhamento e enigma. 


\author{
"Qu'importe que ce soit une maladie, \\ une tension anormale, si le résultat \\ même, tel que, revenu à la santé, je me le \\ rappelle et l'analyse, renferme au plus \\ haut degré l'harmonie et la beauté..." \\ TH. DOSTOIEVSKY \\ L'Idiot (parte 2a , cap. V) \\ (Tradução de Victor Derély)
}

(SÁ-CARNEIRO, 1995, p.418) ${ }^{5}$

A epígrafe de Dostoiévski associa como normal e sem contradição as expressões "maladie", "tension anormale", "harmonie" e "beauté". Deixando lado a lado ideias que aparentemente se mostram contraditórias, mas que dentro do universo literário em que estão inseridas são possíveis de se harmonizarem. Na literatura carneiriana, somos também levados a crer na concepção de que a vida pode ter ações e sentimentos dos mais contraditórios, do bem ou do mal, misteriosos ou não, sem que isso precise de qualquer relação com moralidades pré-estabelecidas. Não importa que a primeira acepção a que a palavra "doença" nos remeta seja a de um universo de enfermidades, do que é combatido, indesejado, ruim; ela pode, e consegue, neste novo universo misterioso e do mal, ser digna de produzir beleza.

O mistério está colocado nas nove narrativas de Céu em Fogo que, em harmonia com a epígrafe, é iniciado pelo conto "A grande sombra". Neste texto, o narrador inicia seus escritos com o termo "- O MISTÉRIO..." (SÁCARNEIRO, 1995, p. 419). O substantivo abstrato "mistério" é posto antecedido por um artigo definido e esta opção configura não apenas uma escolha estética, mas, associada ao uso das letras maiúsculas, ela gera uma espécie de personificação do termo. A palavra ganha suntuosidade e pode ser visto o destaque a ela dado pela própria proposta de visualidade que as letras maiúsculas a ela conferem. As reticências que seguem mostram a incapacidade do narrador em explicar os fatos que narrará em seu texto posteriormente.

5 "Qual é o problema de ser isso uma doença? - decidiu finalmente. - Qual é o problema se essa tensão é anormal, se o próprio resultado, se o minuto da sensação lembrada e examinada já em estado sadio vem a ser o cúmulo da harmonia, da beleza..." (DOSTOIÉVSKI, 2002, p. 261). 
Embriagado pelo tédio e em busca de uma ilusória satisfação e superação da angústia, o narrador nos conta como ele encontra na captação do mistério, na fixação do mesmo, a possibilidade de redenção e um caminho para a saída do cotidiano, de tudo aquilo que ele atribui como simplório, como mundano, e que é motivo de tanto desprezo por inseri-lo numa vida banal.

Ele vê:

A suntuosidade inigualável do mistério!...

Sim! Desde criança adivinhei que a única forma de volver rutilante uma vida. E bela, verdadeiramente bela em ameias a marfim e ouro - seria lograr referi-la ao mistério, incluí-la nele... Mas como, meu Deus, como? (SÁ-CARNEIRO, 1995, p.420)

O fragmento do conto é uma espécie de anúncio do desafio que está posto na vida do narrador, pois, como ele pretende estar envolto no mistério, que se caracteriza pela sua "suntuosidade inigualável", a fim de constituir uma vida rutilante, sua tarefa era justamente a de descobrir como seria possível tal feito. O brilho desta vida desejada só seria possível se a mesma fosse envolta num grande enigma, carregada de incertezas, cujos limites entre 0 real e 0 projetado, entre o fato e o relato se fundissem num abismo de sensações improváveis. Ele nos afirma, contundentemente, que sabe desde criança que a única maneira de viver uma vida "rutilante" seria envolvendo-a em mistério, ou seja, uma vida possível apenas a alguns que são considerados os escolhidos e iniciados no mundo das artes, os capazes de criar uma vida cingida pelo suspense, por ações aflitivas e emocionantes que os tirasse da rotina e que, para além de todas estas características, fosse uma vida que se realizasse no plano da criação.

O que surpreende neste relato é como é dada uma inversão daquilo que seria o mais provável. Não é o mistério que permeia a vida do homem, é o homem que tem sua vida incluída no mistério. A vida real fica em segundo plano nesta dimensão e, mais que uma simples constatação, percebemos o tamanho do desafio que perseguirá o narrador por toda sua trajetória: o de criar uma nova realidade que se tratará por "mistério". Uma realidade em que o "real" é pura 
criação, sendo esta mais forte e importante do que a própria vida e se caracterizando pela força do poder da imaginação.

Em muitos momentos da obra, o mistério vem embalado pela temática do desencontro, da vida que não se realizou. Ainda em "A grande sombra", nosso protagonista se coloca sentado em um restaurante parisiense quando vislumbra:

[...] qualquer rapariga que, à sobremesa, me perguntou o nome francês do doce que eu comia... Falamos alguns minutos, depois. Era russa, de Moscou... E eu dum país distante, ao Ocidente, perdido em aventura... Despedimo-nos sem sabermos os nossos nomes... Não nos tornamos a ver. (SÁ-CARNEIRO, 1995, p. 425)

O que poderia ser apenas um encontro fortuito se mostra muito maior à medida que acaba sendo este encontro o momento singular da história. Saindo do plano factual e engendrando em uma realidade criada, o simples ganha ares de significativo, pois, mesmo parecendo apenas mais um encontro banal, em meio a tantos que vivenciamos todos os dias, ele torna-se singular e repleto de encanto. A moça que, a principio, é "qualquer rapariga", não é apenas isso, ela é a rapariga "russa, de Moscou". Ela traz consigo o mistério de um grande centro urbano com as potencialidades já apontadas no capítulo anterior e que, para um português da época, era muito distante e desconhecido e, portanto, muito difícil de ser explorado. Ela representa o exótico, faz a ligação desse texto com toda uma tradição literária que o autor valorizava, como bem vemos pela escolha de 0 idiota para a epígrafe. Ela representa, como veremos adiante, o encontro, o momento sublime e, desta forma, a eternização do instante na realidade criada.

A impossibilidade de viver algo no plano real com a moça russa em nada incomoda o narrador; a personagem não se mostra decepcionada pelo fato de nem ao menos saber o nome da mulher, pois, ainda que por um instante, os dois, a moça russa e ele, adentraram no que chamamos de "campos do pertencimento". O termo "campos do pertencimento" é a designação da capacidade de fixar um instante a tal ponto significativo que o fixador é capaz 
de fazer com que o objeto fixado passe a lhe pertencer, pois o mesmo, a partir de então, Ihe fica gravado na memória. Não havendo uma necessidade de encontro no plano do real, pois este já se deu no plano do imaginário, do irreal, da criação. $O$ fato das personagens terem suas vidas entrecruzadas pelo olhar faz com que o outro pertença ao fixador. Nessa perspectiva, pertencer ao outro não passa pela acepção vulgar de que ambos precisem se conhecer e vivenciar experiências juntos, sendo assim possível a experimentação de toda e qualquer realidade nova.

A intolerância à realidade é a propulsora deste tipo de ação, pois o real, que é motivo de queixas e imperfeições, é o estímulo à criação literária, à busca pelo mundo imaginário, seja este vivido ou não, seja ele factual ou apenas real dentro dos "campos do pertencimento". A valorização do artificial, da criação, da imaginação, que são expressões tipicamente artísticas, ganha força na obra, não importando se o fato narrado realmente aconteceu, pois ele pôde ser imaginado e criado e é deste encontro que surge a fruição criativa. "É a ficção, a escrita que verossimiliza o inverossímil [...]. É, pois, a linguagem literária que dará realidade a essas figuras imaginárias [...]." (RIBEIRO, 2006, p.44).

Assim, o relato é mais importante que o fato e, como se viu no fragmento, nada impede que o encontro se dê. Este momento, que se configura na realidade paralela, é um recurso para escapar da impessoalidade e da falta de relações do mundo do narrador. A solidão, o desencontro não se configuram nesta perspectiva, causando um efeito oposto ao sentido pelo eu de "À uma passante", de Charles Baudelaire, em que a multidão afasta a mulher desejada pelo eu lírico e seu afastamento gera a impossibilidade de realização do encontro e da felicidade. Em Sá-Carneiro, o afastamento não importa, pois o encontro se dá numa outra dimensão. É neste ponto que o mistério se faz, pois, do desencontro, temos misteriosamente o estímulo para um momento maior, de plenitude, não traduzível em termos do concreto; temos um espaço e um tempo marcados pela magia da transcendência, do imaginário, do sonho e do improvável.

Outro exemplo deste recurso se dá ainda no mesmo conto, quando o narrador, em viagem "[...] à capital do Império sombrio e denso da minha nostalgia 
roçagante..." (SÁ-CARNEIRO, 1995, p. 427) mais uma vez, vê a possibilidade de gravar um novo momento. Sua viagem interior, à realidade criada e habitada por ele, suas lembranças e imagens surgem marcadas pelos adjetivos "sombrio", "denso", "roçagante", indicadores da ambiência enigmática que esta nova realidade apresenta. $O$ encontro com uma mulher desconhecida é assim descrito:

E nos grandes cafés d'Europa, mais frisantemente, os meus olhos detêm-se naquela linda mulher de luxo que, aborrecida em face de seu cálice, espera - à tarde - por um amante, sem dúvida... Olho-a... Insensivelmente vou compondo a sua vida... Engalano-a, poetizo-a; dramatizo-a conforme o seu rosto - e o brilho dos seus olhos, a curva da sua boca maquilhada, o tom de seus cabelos... Uma vida, para mim, foi sempre função de todo um perfil... encontro desfechos apropriados a cada beleza - detalhes que só podem ser vividos por certos olhos, certas mãos, certos sorrisos...

Segue todo o enredo... A matiz, todo o seu passado é sugerido... até que o amante chega, por último... ou não chega, pois nem seria esperado, talvez...

Mas a estrangeira levanta-se, sai... Sigo-a ainda com a vista até desaparecer... e fico tão feliz... tão feliz... tão lisonjeiramente feliz... Mais feliz do que se eu fosse o amante -0 amante mesmo que não chegou - porque então conhecê-la-ia toda: não poderia criar uma vida à sombra daqueles olhos, uma vida de acordo com esses gestos...

Glória marchetada! Sem ela duvidar sem mo permitir, eu entrei, entrei em verdade, na sua existência - porque no meu mundo interior A incluí, imaginando-a suavemente... (SÁCARNEIRO, 1995, p. 427).

O narrador nos conta como ele observa, imagina, supõe, cria, manipula uma cena, utilizando um vocabulário característico do processo de criação: "Olhoa... [...] vou compondo sua vida...", "poetizo-a", "Segue todo o enredo.". Não temos acesso aos fatos, não há nenhuma outra presença que possa testemunhar o ocorrido, por exemplo, o que temos é o relato que por ele nos é dado, a partir de seu olhar, assumindo o papel de flâneur, que se entrega a caminhar pela multidão com seus olhos despertos e prontos para preencher seus próprios vazios interiores "[...] quando preenche o vazio, criado pelo seu próprio isolamento, com os interesses, que toma emprestados, e inventa, de desconhecidos." (BENJAMIN, 1989, p.54). 
O que ele nos conta é aquilo "que toma emprestado, e inventa" de uma moça sentada num café. Mesmo sem ter nenhuma informação privilegiada a ponto de saber a causa da espera da jovem, ou até mesmo se ela efetivamente esperava por alguém, ele conclui que ela lá está à espera do "amante mesmo que não chegou". Neste processo de composição, a inspiração surge da realidade, de uma visão, mas aos poucos esta perde seu peso e a criação propiciada pela imaginação e pela linguagem é que desponta em primeiro lugar, sendo evidenciado que o processo de composição está em pleno andamento no ato da enunciação, marcado pelo titubeio do período "até que o amante chega, por último... ou não chega, pois nem seria esperado, talvez...”.

A vida toma a proporção de "Uma grande sombra" e dentro do contexto do mistério em que está inserida, nos remete ao conceito junguiano que diz ser a "sombra" uma das estruturas da personalidade do homem, sendo que esta se caracteriza por ser "Tudo que nele for individual [...]" (JUNG, 1977, p.27), mas não uma individualidade qualquer, é a parte da individualidade que "[...] submerge, isto é, está condenado à repressão: os elementos individuais caem no inconsciente onde, geralmente, se transformam em algo de essencialmente pernicioso, destrutivo e anárquico." (JUNG, 1977, p.27), "todo individuo é acompanhando por uma sombra e, quanto menos ela estiver incorporada a sua vida consciente, tanto mais escura e espessa ela se tornará." (JUNG, apud PIERI, 2002, p.423). A ambiência ideal para a manifestação da "sombra" se dá no mistério, pois, nele, os crimes, as ações imorais e sem censura não apenas podem acontecer, como são os ingredientes essenciais desta.

A ausência de luz que caracteriza a sombra é a glória para o narrador, ela é a possibilidade de adentrar numa dimensão singular que oprime e liberta ao mesmo tempo. Uma dimensão feita através da delicada técnica de marchetaria, que, de pedacinho em pedacinho, possibilita que o narrador forme seu mundo num processo de acumulação de sombras, evitando sempre chegar à luz. A marchetaria é uma imagem recorrente na obra de Sá-Carneiro e ela bem representa a ideia do labor artístico. As palavras, tais quais os pequenos recortes de madeira, marfim e metal, devem ser bem calculadas e distribuídas para que formem um conjunto harmônico, dotado da delicadeza e da precisão 
necessárias para que o texto represente em seu todo a beleza desejada, associada à liberdade, ainda que esta liberdade criativa seja carregada de sombras e "momentos luminosos" atribuídos ao mal.

\section{2 - O "momento luminoso"}

Charles Baudelaire no texto "O mau vidraceiro", de Pequenos poemas em prosa, nos dá pistas para a compreensão do que venha a ser a ideia de "momento luminoso". O poeta nos relata o dia em que um vidraceiro passa pelas ruas de Paris carregando seu mostruário de vidros e é interpelado por ele, que se mostra interessado na mercadoria. Custosamente, o vendedor sobe todas as escadas do prédio para chegar com seus vidros ao possível comprador. Percebendo não ser o almejado pelo dono do apartamento, o vidraceiro se vê escorraçado escadaria abaixo. Não satisfeito em ter solicitado ao homem que subisse tantos andares com uma mercadoria frágil e pesada, 0 narrador articula uma estratégia para ver quebrarem-se gratuitamente todos os vidros. Ao observar o que fora capaz de fazer, nosso narrador conclui que: “Existem naturezas puramente contemplativas e totalmente impróprias para a ação que, no entanto, movidas por algum misterioso e desconhecido impulso, agem às vezes com uma rapidez de que elas próprias julgariam incapazes." (BAUDELAIRE, 2006, p.53).

Muitas das ações promovidas pelas personagens carneirianas sofrem de mesmo impulso, um impulso "misterioso e desconhecido". Impulso este que é capaz de fazer "naturezas puramente contemplativas e totalmente impróprias para a ação" prontas a promoverem atos cruéis, impensados, intempestivos. Movidos pelas mudanças do final do século e pela dificuldade de se inserir num mundo em plena transformação e efervescência tecnológica; o homem deste momento vê-se perdido em seu papel, o que the causa forte tendência à crise da identidade. Desta dificuldade de se reconhecer, pode-se dar origem a uma introspecção, que faz com que as relações humanas fiquem gradativamente mais fragilizadas, dando margem ao aparecimento do tema do desencontro, da angústia, do "não ser", como registrado em "Quase”, poema de Dispersão, que 
apresenta um eu explicitando que, para tudo o que desejava, faltou-Ihe apenas um pouco para conseguir.

Um pouco mais de sol - eu era brasa, Um pouco mais de azul - eu era além.

Para atingir, faltou-me um golpe d'asa...

Se ao menos eu permanecesse aquém...

Assombro ou paz? Em vão... Tudo esvaído

Num baixo mar enganador de espuma;

E o grande sonho despertado em bruma,

O grande sonho — ó dor! — quase vivido...

Quase o amor, quase o triunfo e a chama,

Quase o princípio e o fim - quase a expansão...

Mas na minh'alma tudo se derrama...

Entanto nada foi só ilusão!

$[\ldots]$

(SÁ-CARNEIRO, 1995, p.65)

Na expectativa de superar a agonia de ser "quase", uma das possibilidades é a de envolver a vida em mistério pela criação de outra realidade e, uma vez estando nesta, compô-la de "momentos luminosos", instantes significativos. A busca por estes instantes, pela "Glória marchetada!" (SÁ-CARNEIRO, 1995, p.427), pelo ápice das sensações levadas ao extremo é que faz com que muitos eus e personagens sejam vitimas e algozes de ações representativas do mal.

A complexidade de se vivenciar o mundo do mistério é tão exacerbada, que Lúcio, de A confissão de Lúcio, em suas páginas confessionais, nos conta saber que o preço a ser pago pelo seu instante glorioso nem poderá ser compreendido pelos leitores de sua confissão, mas que ainda assim ele a redigirá:

[...] ignoro se é felicidade maior não se existir tamanho instante. Os que não o vivem têm a paz - pode ser. Entretanto, não sei. E a verdade é que todos esperam esse momento luminoso. Logo, todos são infelizes. Eis pelo que, apesar de tudo, eu me orgulho de o ter vivido. (SÁ-CARNEIRO, 1995, p.451-452) 
A felicidade se mostra condicionada ao "momento luminoso" e o narrador, num primeiro momento, aponta que aqueles que não o vivem encontram a paz, mas imediatamente se corrige dizendo que "todos esperam pelo momento luminoso. Logo, todos são infelizes.”. A paz, neste contexto, não passa de uma ilusão de felicidade e, consciente disso, ele se mostra orgulhoso de ter vivido o que viveu, ainda que seu destino tenha sido o de nos contar os relatos do ocorrido da cadeia onde passou "[...] DEZ ANOS de prisão por um crime que não pratiquei e do qual nunca me defendi [...]." (SÁ-CARNEIRO, 1995, p.351).

A experiência do grande instante se mostra muito superior a todas as outras experiências já vividas pelo homem. Nesta perspectiva, mais vale o risco de se envolver em alguma situação que possa sair do controle, mas que se mostre potencialmente reversível a um instante fixado e significativo, a ter que passar pelo resto da vida apenas como um mero expectador.

Em um momento intratextual de personagens carneirianos, a parte final da confissão é a apresentação feita por Lúcio, daquele que é o protagonista de "O fixador de instantes". Lúcio nos aponta, em suas breves palavras, não apenas as características físicas da personagem, nem tampouco apenas o crime pelo qual fora condenado. Ele nos revela o projeto que envolve o protagonista de "O fixador", nos introduzindo na ideia de que "a arte da sua vida" nada mais era que a busca interminável pelo "instante significativo", pela "fixação do instante", só possível pela capacidade de criar e divagar tão apurada naqueles que são os eleitos, os consagrados para viver uma vida na "suntuosidade inigualável do mistério!" (SÁ-CARNEIRO, 1995, p.420).

Para ele como para mim também a vida parara - ele vivera também o momento culminante a que aludi na minha advertência. Falávamos por sinal muitas vezes desses instantes grandiosos, e ele então referia-se à possibilidade de fixar, de guardar, as horas mais belas da nossa vida - fulvas de amor ou de angústia - e assim poder vê-las, ressenti-las. Contara-me que fora essa a sua maior preocupação na vida - a arte da sua vida... (SÁCARNEIRO, 1995, p.414) 
Tomado pela angústia, o tema de "O Fixador de Instantes", oitavo conto do livro Céu em Fogo, se dá pela incapacidade de se estabelecer e perpetuar relações interpessoais, fazendo com que a única saída seja a captura, o congelamento, a fixação do instante. Sendo que esta fixação não se dá no campo da realidade factual, como já vimos anteriormente, mas sim no do mistério da realidade criada. Após teorizar sobre seu projeto durante seis blocos de texto ${ }^{6}$, o narrador muda abruptamente de assunto e nos relata seu encontro com uma rapariga. A funcionalidade desta descrição nos parece apenas que se dê a exemplificar a teoria por ele expressa até aquele momento do texto.

O sentimento dele por ela, marcado nas linhas iniciais da descrição é "Amo-a tanto... tanto..." (SÁ-CARNEIRO, 1995, p.534). O amor ali deflagrado fica sem contexto dentro da narrativa, mas à medida que os fatos nos são contados, a mulher que despertou no narrador uma alegria tão grande, a ponto de fazê-lo declarar que "Quando ela me surgiu, a resvalar longínqua e fulva, eu tive a sensação de não ser um habitante da vida." (SÁ-CARNEIRO, 1995, p.534) é a mesma que desperta nele a ação de cravar "no peito um estilete áureo" (SÁCARNEIRO, 1995, p.537), levando-a a morte.

O crime, que fora cometido nas páginas finais da narrativa, foi premeditado. "Sou todo medo, subtil quebranto, em face à obra genial que devo altear - que altearei se for." (SÁ-CARNEIRO, 1995, p.535). O crime é visto como sua obra genial, como aquilo que enfim o levará até a plenitude da fixação. Embalado por um medo flébil, ele sabe que poderá sofrer as consequências de sua atitude, mas não titubeia. "Hei-de vivê-lo. Embora. Terei sido luz! A vitória! A vitória!" (SÁ-CARNEIRO, 1995, p.536).

O momento enfim aconteceu:

A glória fora excedida! O instante que eu delirara não era só maior, era mais alguma coisa: em face dele, todos os momentos que vivera já se abatiam como espuma. Sim! Sim! Por terra, derrocadas, jaziam todas as minhas horas! E sob as ruínas, esmagava-me eu sem nunca mais me poder ressurgir - excepto se lograsse à força d'alma, fixar o instante sublime que me havia

\footnotetext{
${ }^{6} \mathrm{O}$ texto apresenta-se dividido em sete blocos.
} 
agitado: o Instante da minha vida, agora e para sempre, era irremediável... (SÁ-CARNEIRO, 1995, p. 536)

O desafio maior de fixar "o Instante da minha vida" estava posto e a coragem para prosseguir foi toda tomada.

Quando ela adormeceu, surgira-me enfim a ideia genial. E venci-a! Venci-a!

Primeiro tive medo. Em face da maravilha todos têm medo. Mas depois fui audacioso.

Ritualmente, bem lúcido, avancei sobre as rosas desfolhadas... [...] Um arrepio de beleza se me eternizou... Aconcheguei-lhe as tranças e, de mansinho - não a fosse desmoronar — cravei-lhe no peito um estilete áureo...

Os cabelos sonorizaram-se-lhe, logo volvidos silêncio outonal... toda a carne ondeou num arqueamento de luz... E nem mais uma vibração...

Trinquei-lhe as pontas dos seios mortos. Fugi... (SÁCARNEIRO, 1995, p.537)

Assim se concretizara o projeto maior (“E venci-a! Venci-a!”). O resto ficou sem importância perante o infinito de sensações que foram sentidas e eternizadas naquele momento (“Um arrepio de beleza se me eternizou..."). O tempo cronológico perderá completamente seu sentido e o mítico, irreal ganhou lugar e valor.

A compreensão da ação praticada por ele é tão particular, que o mesmo afirma que se a vítima "[...] soubera havia de me abençoar..." (SÁ-CARNEIRO, 1995, p.537). O sofrimento manifestado é apenas um ato retórico, pois no cerne ele sabe exatamente o porquê de ter tomado aquela decisão e como a mesma era especial em sua vida.

Matei-a para não a acordar dentro de mim.

Há maravilhas que só devem ser sonhadas.

E eu sonhar-te-ei sempre, meu amor!...

Vitória! Vitória!

Nunca mais esquecerei os teus beijos, pois logo os perdi; nunca mais olvidarei os teus seios, pois mal os conheci. Fundi a saudade universal na saudade do teu corpo - saudade que só eu edifiquei, pois só eu o detive. (SÁ-CARNEIRO, 1995, p.537) 
Embora o narrador peça o perdão da mulher ao dizer "Tu perdoas-me!" (SÁCARNEIRO, 1995, p.537), o fato é que ele coloca seu projeto em primeiro lugar, pois crê que "Há maravilhas que só devem ser sonhadas." e a possibilidade de se estreitar a esta mulher a ponto de percebê-la de maneira mais real, macularia toda "[...] a sua beleza [...]" (SÁ-CARNEIRO, 1995, p.536), que "Não findava nunca [...]" (SÁ-CARNEIRO, 1995, p.536) e que despertara nele a necessidade de reter "[...] a Cor do ar, o seu perfume revolto, o seu timbre leonino... e as sedas, as peles, as rendas... as taças de cristal, os candelabros d'oiro... as folhas de amaranto... os gumes de punhais..." (SÁCARNEIRO, 1995, p.536).

Ao constatar "Sou o Instante." (SÁ-CARNEIRO, 1995, p.537) nas linhas finais do texto, o narrador aponta que ele deixa de simplesmente fixar o instante, para tornar-se o mesmo. Ele passa a ser o dono, o manipulador, o próprio tempo, concluindo aos que desejariam saber mais de tudo que o cercara, de que o resto não passava de "A grande sombra! A grande sombra!..." (SÁCARNEIRO, 1995, p.538). Novamente a imagem da sombra aparece para encerrar o conto e apontar para outro fenômeno potencializado pela congruência entre a fragmentação da identidade, a criação de outro "real" e a valorização do mistério: o universo do duplo.

\section{3 - A presença do duplo na manifestação do "eu" e dos "outros"}

As pinturas rupestres encontradas nas cavernas são uma forma primitiva e inicial da representação, nelas estava a gênese da cópia. Quando um homem saía para caçar e ao voltar se dava ao capricho de pintar uma forma icônica de seu feito, ele manifestava a intenção de seu desdobramento. Seu eu, retido e limitado a uma única faceta, se perpetuaria no tempo através das formas registradas. Desta maneira, seria possível, mesmo após a passagem inexorável do tempo, voltar a buscar através daquela imagem, um momento, um instante congelado na memória, que seria despertado pela visão. Caso não fosse o próprio retratado que estivesse contemplando a imagem um dia 
pintada, seu novo expectador seria capaz de entrar em contato com o momento, pela reprodução imagética daquilo que supõe ter sido real. A representação será capaz de transportar o contemplador para a ideia daquilo que aconteceu num determinado momento da existência do contemplado.

Qualquer que seja a forma da percepção, a imagem riscada na parede da caverna nada mais é que o duplo de uma situação original. Percebe-se aí uma vontade quase irracional do homem de se desdobrar, se perpetuar, se multiplicar, pois de alguma forma esta atitude pode ser uma maneira de enganar a morte, mantendo-se vivo através dos tempos. Seja pela necessidade de ser muitos e, assim, poder se subdividir, ou ainda, pelo prazer de tal faceta, o homem sempre gostou de promover e registrar sua duplicação.

Platão (2009), em O Banquete, apresenta o duplo como o castigo imposto aos seres (homem, mulher, andrógeno) por estes terem ousado escalar o Olimpo para desafiarem os deuses. A eles coube o infortúnio de serem cingidos, desdobrados e que por esta característica se tornaram seres incompletos e enfraquecidos, que passarão suas existências em busca da completude perdida, do encontro com seu outro. Na Bíblia, "[...] o homem começa sendo um. Deus corta o homem em dois; [...] o homem é interpretado como possuidor de uma natureza dupla - em particular masculina e feminina." (BRUNEL, 2005, p. 262).

Segundo Carla Cunha, no Dicionário de Termos Literários, de Carlos Ceia, para o vernáculo "duplo" temos aquele que confere a algo a condição de desprendimento e projeção de sua gênese. É a entidade que, após sua individualização, gera existência própria e pode, a partir de então, se desprender do original ou partir numa eterna luta de espaços. Sendo assim, o duplo:

[...] é uma entidade que duplica o "eu", destacando-se dele e autonomizando-se a partir desse desdobramento. Gera-se a partir do "eu" para de imediato, dele se individualizar e adquirir existência própria. A sua coexistência como o "eu" de que é originário, contudo, nem sempre é pacífica. (CEIA, 2011, s/p) 
A questão do duplo na literatura remonta tempos. Segundo Clement Rosset (2008), os gregos, que registraram em suas obras inúmeros exemplos de encontro com o duplo, como na saga de Édipo, em Édipo Rei, de Sófocles, ou em páginas mais modernas, como as de Oscar Wilde em $\mathbf{O}$ retrato de Dorian Gray.

Muitos são os exemplos de como o duplo se manifesta e está presente na cultura, e um dos escritores que melhor se apropriou deste conceito e não pôde fugir da agrura de vivenciá-lo em sua obra foi Mário de Sá-Carneiro. Encontramos na obra do autor um conjunto de vozes e personagens que, durante todo seu processo de composição, se desdobram em muitos e são representativos de um universo dotado de fragmentação e artificialismo. Nos caminhos da alma desdobrada, as personagens e eus sofrem as consequências de serem muitos em um só. $\mathrm{O}$ que, de alguma maneira, poderia ser bom, pois carregaria a possibilidade de alegria pela multiplicidade, pode também deixar flagrante o eterno descontentamento com a individualidade.

Segundo Rosset (2008), a questão do duplo se dá pelo reconhecimento e/ou a reprovação daquilo que vemos.

\footnotetext{
Reconhecimento do fato anunciado e reprovação porque o acontecimento não se produziu de outra maneira. Reconhecimento e reprovação são inseparáveis um do outro e significam, em essência, a mesma coisa: ou seja, um olhar sobre a "estrutura" do único. O único satisfaz a expectativa ao se realizar, mas frustra eliminando qualquer outro modo de realização. (ROSSET, 2008, p. 46)
}

É justamente deste reconhecimento de si e sua reprovação que o desdobramento se mostra adequado. O duplo acaba sendo uma saída e uma transgressão da vida cotidiana, pois pode ser através dele que o eu se projete e fuja, além de ser no caso carneiriano um processo de composição. 
Em Mário de Sá-Carneiro, uma das facetas da duplicidade se dá pelas recorrências temáticas, como a presença do onírico e da homossexualidade nas realizações amorosas, por exemplo. Em consonância às teorias de Platão (2009), as personagens cingidas se mostram solitárias e incompletas, fazendo com que elas carreguem em si a angústia de tentar se reconhecer no outro e, assim, arrefecer sua natureza dupla. A homossexualidade aceita em tempos platônicos aparece consentida na obra se vivida no plano do sonho, da transmutação, da criação de uma outra realidade. Assim se fez o amor de Marta/Lúcio/Ricardo, em A confissão de Lúcio, que só se "realiza" à medida que Ricardo se duplica. Mesmo fenômeno ocorrido com Inácio de Gouveia no conto "Ressurreição", em que a personagem só é capaz de amar Etienne, quando se dá a morte de Paulette e num cemitério os amantes se encontram, fazendo-nos crer que a ressurreição se dá no corpo dele - “... Até que um dia, sem saberem como, os seus corpos nus, masculinos, se entrelaçaram..." (SÁCARNEIRO, 1995, p.581).

A realização do amor nestes dois exemplos, se dá pela perspectiva do que Rosset (2008) chama de ilusão. A ilusão é a capacidade de "[...] transformar um único fato em dois fatos divergentes, uma mesma ideia em duas ideias distintas - uma desagradável, mas a outra 'muito diferente' [...]." (ROSSET, 2008, p.23). A realidade intolerável e angustiante a que as personagens se mostravam submetidas dá lugar a uma realidade forjada por elas. Uma realidade em que estas são capazes de se sentirem completas e menos suscetíveis aos infortúnios comuns aos homens. Nesta nova realidade, a ilusão permite que as ações sejam percebidas com exatidão, mas que suas consequências sejam deliberadamente ignoradas (ROSSET, 2008).

Não apenas as personagens e eus se mostram duplicados na obra de Mário de Sá-Carneiro, mas também os temas do autor, como o do amor não realizado. No poema "Como eu não possuo", de Dispersão, escrito em maio de 1913, as mesmas ideias que, segundo Martins (1994), são o motivo inspirador de A confissão de Lúcio, fazendo do mesmo uma versão resumida da obra em si. 


\section{COMO EU NÃO POSSUO}

Olho em volta de mim. Todos possuem Um afeto, um sorriso ou um abraço.

Só para mim as ânsias se diluem

E não possuo mesmo quando enlaço.

Roça por mim, em longe, a teoria

Dos espasmos golfados ruivamente;

São êxtases da cor que eu fremiria,

Mas a minha alma pára e não os sente!

Quero sentir. Não sei... perco-me todo...

Não posso afeiçoar-me nem ser eu:

Falta-me egoísmo para ascender ao céu,

Falta-me unção pra me afundar no lodo.

Não sou amigo de ninguém. Pra o ser

- Forçoso me era antes possuir

Quem eu estimasse - ou homem ou mulher,

E eu não logro nunca possuir!...

Castrado de alma e sem saber fixar-me,

Tarde a tarde na minha dor me afundo...

- Serei um emigrado dentro do mundo

Que nem na minha dor posso encontrar-me?...

Como eu desejo a que ali vai na rua,

Tão ágil, tão agreste, tão de amor...

Como eu quisera emaranhá-la nua,

Bebê-la em espasmos de harmonia e cor!...

Desejo errado... Se a tivera um dia,

Toda sem véus, a carne estilizada

Sob o meu corpo arfando transbordada,

Nem mesmo assim - ó ânsia! - eu a teria...

Eu vibraria só agonizante

Sobre o seu corpo de êxtases dourados,

Se fosse aqueles seios transtornados,

Se fosse aquele sexo aglutinante...

De embate ao meu amor todo me ruo,

É vejo-me em destroço até vencendo:

É que eu teria só, sentindo e sendo

Aquilo que estrebucho e não possuo.

Paris, maio de 1913

(SÁ-CARNEIRO, 1995, p.67-68)

Não ser amigo de ninguém, pois para sê-lo forçoso seria transformar ou transformar-se para poder possuir o objeto amado, que aparece na quarta estrofe do poema, surge na voz de Ricardo ao confessar ao amigo Lúcio sua incapacidade de relacionar-se: 
[...] não posso ser amigo de ninguém... [...] um desejo de beijar... de estreitar... Enfim: de possuir! [...] Para as sentir, isto é para ser amigo de alguém (visto que em mim a ternura equivale à amizade) forçoso me seria antes possuir quem eu estimasse, ou mulher ou homem [...]. (SÁ-CARNEIRO, 1995, p.376)

A angústia da identidade e seus desdobramentos foram tema de outras obras de Mário de Sá-Carneiro, como nos poemas "Dispersão", "7", "Aquele Outro", ou ainda, no conto "Eu-Próprio o Outro". A obsessão anunciada pela recorrência temática está muito centrada na ideia da ausência, da incompletude anunciada por Platão e da busca constante e inalcançável da superação desta dificuldade.

Mesmo em textos que aparecem com uma temática aparentemente diferenciada, notamos um mesmo padrão de personagem. Um eu que se mescla, que se mistura, que se dilui na personalidade de um "outro", não deixando ser possível constatar se é um que se desdobra ou o outro que se funde, mas, de qualquer forma, ambos perdem a identidade por em muitas vezes não apresentarem um limite claro de quem vem a ser o "eu" e quem vem a ser o "outro".

Em "O sexto sentido", conto publicado em Princípio, temos uma narrativa contada por um narrador personagem onisciente - "NO FIM DESSE JANTAR de anos a conversa recaíra sobre as ciências ocultas." (SÁ-CARNEIRO, 1995, p. 298) que no ato da enunciação já está temporalmente distante do momento do enunciado - "Num desvairamento avançava para mim com os punhos cerrados. Os seus olhos chispavam. Confesso tive medo" (SÁ-CARNEIRO, 1995, p.301). O narrador nos conta que durante um jantar, um médico, o Dr. Gouveia, tinha como assunto principal as ciências ocultas. Ele, na ocasião, fez uma explanação de como "[...] não tardaria muito tempo em que todos saberiam o que todos pensavam." (SÁ-CARNEIRO, 1995, p.298). A explanação do médico pareceu a Patrício Cruz, num primeiro momento, completamente descabida de razão e cientificismo, pois se resumia a dizer que: 
[...] cada pensamento, cada ação, cada palavra, provoca uma vibração que se propaga nas camadas mais aéreas tal como nas ondas luminosas, elétricas ou caloríficas. Ninguém ignora que arremessando-se à água com uma pedra, se formam umas ondulações devidas ao choque desse corpo sólido com o meio líquido. Pois bem: quando se arremessa ao ar com uma palavra, com o pensamento, acontece o mesmo. $\mathrm{O}$ ar é o meio propagador por excelência. É nisso exatamente que repousa a telegrafia sem fios. Ao homem falta apenas o órgão de percepção das ondas aéreas. Esse órgão é o do "sexto sentido". Dele já deve existir um crepúsculo em todos os cérebros, mais desenvolvidos nalguns, o que explica os fenômenos provados da transmissão de pensamento. (SÁ-CARNEIRO, 1995, p.298)

O narrador não se mostra nada entusiasmado com o discurso do médico, comentando inclusive com traços de ironia que o mesmo durante sua fala "dissera com fumaças de sábio" (SÁ-CARNEIRO, 1995, p.298). Ele não se impressiona, nem tampouco se importaria, não fosse o fato de seu amigo "[...] Patrício da Cruz, primoroso contista [...]" (SÁ-CARNEIRO, 1995, p.289) ter tido uma mudança abrupta de comportamento após a noite do jantar. Ele que tinha "[...] ânimo galhofeiro tornou-se sorumbático: dantes odiava a solidão; agora, fugia de todos os amigos [...]" (SÁ-CARNEIRO, 1995, p.298). Mas o que poderia ter causado tamanha mudança de comportamento?

Os amigos, que eram os mais próximos possíveis - "[...] fugia de todos os amigos - de mim próprio, aquele cujo convívio mais lhe agradava." (SÁCARNEIRO, 1995, p.298) - perceberam e receberam a mesma informação do médico, mas a encararam de maneira muito diferente entre eles. Enquanto um a trata com irrelevância e ironia, o outro se reconhece como dotado do "sexto sentido" e parece tê-lo desenvolvido a partir de então: "Possuo o sexto sentido. Um órgão novo se desenvolveu em meu cérebro: Sou o "homem perfeito", o precursor das gerações futuras!..." (SÁ-CARNEIRO, 1995, p.299).

Neste primeiro exemplo de manifestação do duplo na capacidade de "ler" os pensamentos das pessoas e a partir de então "sentir" o que elas sentiam e, desta forma sê-las é a manifestação de um duplo às avessas. Não é a personagem que se duplica em outros, são os outros que ganham a condição 
de eu, pois uma das características existentes na sua condição de detentor do "sexto sentido" não era a de apenas saber o que se passava no pensamento de seus colegas, mas também, de sentir exatamente o que eles sentiam.

O narrador se "identificava" com alguém e imediatamente passava a vibrar seus sentimentos. "[...] identifiquei-me com a primeira pessoa que vi, um homem idoso já. Desgraçado! Morrera-lhe o único filho, a criatura para quem vivera somente! Sofria duma maneira atroz, e eu... eu sofria portanto atrozmente também!..." (SÁ-CARNEIRO, 1995, p.300). Se aqui reconhecemos um processo de fundição da personagem às outras tantas que ela encontrava em seu caminho, o mais comum na trajetória carneiriana é o desdobramento. $O$ autor apresenta em diversos pontos da obra algumas das faces mais comuns no universo do duplo: a multiplicação do eu, a ideia do espelho, a sombra, a imprecisão da identidade... todas características muito centradas na ideia do mistério, que é o tema de nosso capítulo.

Marta e a Americana, personagens de A confissão de Lúcio, e algumas outras mulheres da obra, são exemplos da construção misteriosa que o duplo é capaz de proporcionar. A Americana, que não apresenta nome próprio e é apenas tratada pela referência de sua origem, esvaziado-a de identidade formal, é assim descrita:

[...] era qualquer coisa de sonhadoramente, de misteriosamente belo. Uma criatura alta, magra, de um rosto esguio de pele dourada - e uns cabelos fantásticos, de um ruivo incendiado, alucinante. A sua formosura era uma destas belezas que inspiram receio. Com efeito, mal a vi, minha impressão foi de medo - um medo semelhante ao que experimentamos em face do rosto de alguém que praticou uma ação enorme e monstruosa. (SÁCARNEIRO, 1995, p. 355)

Já Marta, que compõe o triângulo amoroso do mesmo livro, era:

[...] uma linda mulher loira, alta, escultural - e a carne mordorada, dura fugitiva. O seu olhar azul perdia-se de infinito, nostalgicamente. Tinha gestos nimbados e caminhava nuns passos leves, silenciosos - indecisos, mas rápidos. Um rosto formosíssimo, de uma beleza vigorosa, talhado em oiro..." (SÁ-CARNEIRO, 1995, p. 379) 
Semelhante ao padrão feminino da dançarina de "O fixador de instantes":

Era toda de mistério a encantadora. Ungiam-na ao andar sombras aureoladas, transparentes d'alma, sombras que ela mesma, da sua carne-luz, suscitava em miragem velada. E era oiro golfado a sua voz a enclavinhar-se em luxúria, oiro esbraseado por um sol desconhecido, longínquo e disperso... (SÁ-CARNEIRO, 1995, p. 534)

A atriz Júlia Gama, de "O incesto", último conto de Princípio, era "Duma beleza misteriosa - cabeleira de fogo, olhos de infinito - esboçava-se-lhe nos lábios úmidos o sorriso enigmático da Jucunda. [...] Atraía e afugentava ao mesmo tempo essa mistura de céu e inferno" (SÁ-CARNEIRO, 1995, p.303).

A semelhança física entre elas é notória, uma vez que uma era "qualquer coisa de sonhadoramente, de misteriosamente belo", a outra "toda de mistério" ou ainda "duma beleza misteriosa". Uma era dona de "pele dourada", a outra de "rosto talhado em oiro", já a voz da terceira era "oiro golfado". A sensação que se tem é de que todas elas são apenas uma projeção, uma fantasia, pois, para além das coincidências físicas, todas elas são mulheres que matem a mesma essência, que fazem performances, que despertam medo, que caminham como brisa. Além das sensações de medo e de mistério despertadas pela figura ímpar e plural delas, também é comum o padrão de comportamento que todas despertam nos homens com que se relacionam, elas são sempre vistas como possíveis alvos violentos, mas não pela violência física gratuita, mas sim pela sádica, como ainda veremos nesta tese.

A dama que acompanha o narrador de "Ressurreição", último conto de Céu em fogo, é o objeto amoroso que evoca as vontades de morder e de ferir, assim como a ideia dos heróis da antiguidade que comiam seus conquistados, na crença de que deles adquiririam suas maiores virtudes, é a posse levada ao extremo.

Ah! que triunfo admirável passear pelas ruas de Paris com uma mulher dourada, e possuí-la - estiraçar-se imperialmente sobre a sua carne de aurora, entregar-se todo em amor e anseio fluido!... 
Havia de a morder, de a ferir - sim, de a ferir! — com seus beijos, arroxeadamente... (SÁ-CARNEIRO, 1995, p.548)

A mulher de "O fixador de instantes" é uma bailarina que se apresenta diante do narrador e o deixa absolutamente prostrado perante ela. Ao se apresentar, o bailado desperta em todos as mais diferentes sensações... são evocados "Aromas capitosos", (SÁ-CARNEIRO, 1995, p.534) "sonoridade e pasmo" (SÁCARNEIRO, 1995, p.534). "Era toda de mistério a encantadora." (SÁCARNEIRO, 1995, p.534). A Americana desperta "medo - um medo semelhante ao que experimentamos em face do rosto de alguém que praticou uma ação enorme e monstruosa." (SÁ-CARNEIRO, 1995, p.534).

Dotadas de uma beleza incomum, da capacidade artística, da propagação do mistério, estas mulheres apresentam a essência a que aspiram aos narradores e eu cingidos e incompletos. Elas apresentam em si tudo o que eles, em suas vidas de "quase", gostariam de ser, elas são a representação do inatingível que a toda hora é pleiteado.

Algumas personagens masculinas também se mostram com essências semelhantes. Além do fato de serem artistas, como Raul e Patrício Cruz, de "Loucura", conto de Princípio - "A MORTE DE RAUL VILAR foi muito lamentada. Todos os jornais consagraram longos artigos ao grande escultor." (SÁ-CARNEIRO, 1995, p.264), "Patrício Cruz era um fenomenal talento de escritor." (SÁ-CARNEIRO, 1995, p.269) ou ainda o também escultor Gervásio Vila-Nova, de A confissão de Lúcio,

\footnotetext{
Perturbava o seu aspecto físico, macerado e esguio, e o seu corpo de linhas quebradas tinha estilizações inquietantes de feminilismo histérico e apoiado, umas vezes - outras, contrariamente, de ascetismo amarelo. Os cabelos compridos, se lhe cobriam a testa ampla e dura, terrível, evocavam cilícios, abstenções roxas; [...] Entanto, coisa bizarra, no seu corpo havia mistério - corpo de esfinge, talvez, em noites de luar. (SÁ-CARNEIRO, 1995, p.353)
}

Gervásio teve uma morte trágica e sem grande notoriedade para Lúcio e sua figura, possivelmente, deu lugar ao surgimento de outra personagem - Sérgio 
Warginsky, numa descrição física que denota que um pode ser o duplo do outro:

Era um belo rapaz de vinte e cinco anos, Sérgio Warginsky. Alto e elançado, o seu corpo evocava o de Gervásio Vila-Nova, que há pouco, brutalmente se suicidara, arremessando-se debaixo de um comboio. [...] os cabelos de um loiro arruivado caiam-lhe sobre a testa... [...]. (SÁ-CARNEIRO, 1995, p.380)

As mesmas impressões negativas nutridas por Lúcio a respeito de Sérgio eram as sentidas por Gervásio Vila-Nova, que tudo sabia, que sempre se destacava e fazia discursos a respeito de qualquer assunto. Gervásio, em um de seus discursos públicos, exaltou o "Selvagismo" e a esse respeito apontou Lúcio: "[...] Gervásio seguramente não lera, mas todavia se não cansava de exaltar, gritando-o assombroso, genial..." (SÁ-CARNEIRO, 1995, p.355). A mesma máimpressão dedicada a Sérgio:

De resto era evidente que o poeta dedicava uma grande simpatia ao russo. A mim, pelo contrário, Warginsky só me irritava sobretudo talvez por sua beleza excessiva -, chegando eu a não poder retrair certas impaciências quando ele se me dirigia. (SÁCARNEIRO, 1995, p.380)

Além de casos de desdobramento de personagens em dois ou mais, o das mulheres, ou de Sérgio e Gervásio, temos também personagens que aparecem repetidamente em contos, como o próprio Patrício Cruz, citado anteriormente, que é personagem do conto "O sexto sentido", "Patrício da Cruz, primoroso contista [...]"7 (SÁ-CARNEIRO, 1995, p.298) e de "Loucura" ou ainda o amigo do cárcere de Lúcio, que protagoniza "O fixador de instantes", citado no subcapítulo "O momento luminoso".

No conto "Eu-próprio o Outro", sexto de Céu em Fogo, o narrador diz perceber a criação de um amigo, um outro: "Hoje encontrei-o pela primeira vez." (SÁ-

${ }^{7} \mathrm{O}$ nome da personagem sofre pequena alteração no decorrer do conto. Ele inicia como "Patrício da Cruz, primoroso contista [...]" (SÁ-CARNEIRO, 1995, p.269) e termina o conto ensandecido e chamando-se "Patrício Cruz habita hoje o quarto $n^{\circ} 5$ de Rilhafoles." (SÁCARNEIRO, 1995, p.301) 
CARNEIRO, 1995, p.505), mas a coexistência entre as partes do duplo entra em choque e o "eu" vai gradativamente ficando acuado até que, em poucas linhas, ele diz:

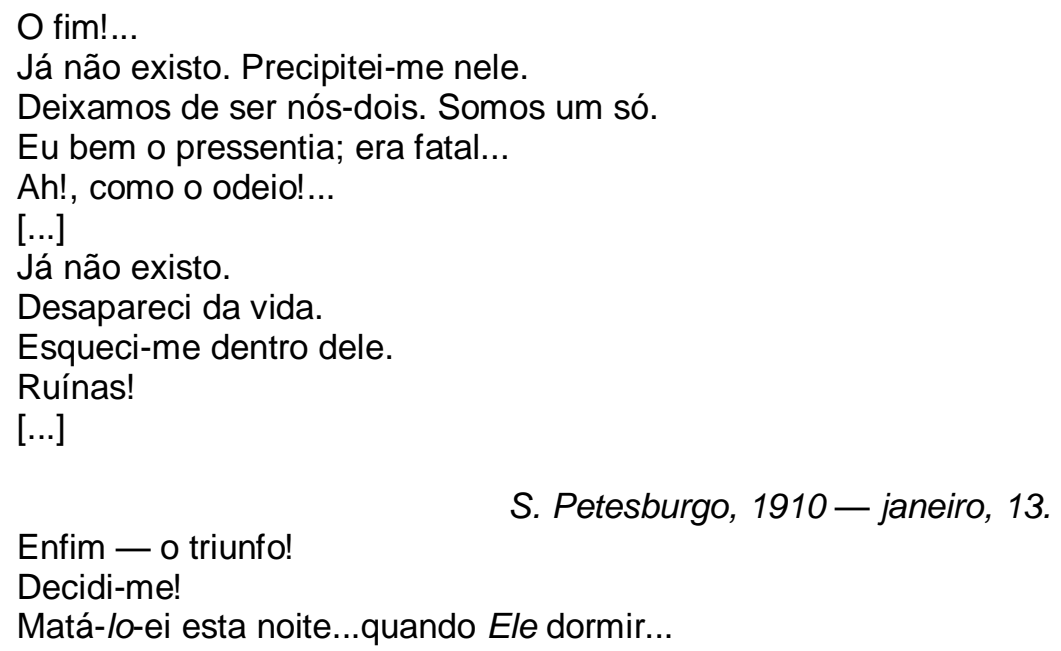

(Lisboa, novembro de 1913.)

(SÁ-CARNEIRO, 1995, p.511-512)

É um caso de duplo que não convive, que precisa se destruir pelo excesso de angústia que causa, mas que mostra claramente o como ele é mais um processo de criação do narrador. Da mesma forma que ele cria, ele mata.

O duplo é uma forma de criação, quando este é a projeção de um outro. Como possivelmente no caso de Ricardo/Marta/Lúcio. Ele permite o mal, porque a culpa se dilui e não se é possível saber quem exatamente é o autor de quais ações. É pela multiplicidade que a sombra pode se realizar e libertar o indivíduo de sua massacrante rotina mundana e proporcionar a ele sua entrada numa nova realidade. A transposição de uma realidade para outra pode se dar no duplo, ele é a "ponte" que viabiliza a comunicação entre estes dois mundos das personagens. 


\section{4 - As mulheres}

Uma vez pensada na duplicidade, não há como não se ater à descrição de muitas das personagens femininas do universo carneiriano. A semelhança nas descrições das mesmas faz com que possamos pensar que todas não passam de uma ou talvez duas, não mais que esta quantidade de tipos femininos, de cópias de uma essência.

O padrão de beleza feminina cultuado por Sá-Carneiro está intimamente relacionado àquilo que Mário Praz classifica como "beleza meduseia". São mulheres que, ao serem descritas, evidenciam:

A descoberta do horror como fonte de deleite e de beleza [...] o horrível, na categoria do belo, terminou por se tornar um dos elementos próprios do belo: do belamente horrível se passou, em graus insensíveis, ao horrivelmente belo. (PRAZ, 1996, p. 45)

Esta mistura entre o "belamente horrível" e o "horrivelmente belo" é também constatada por Roudinesco, quando diz:

[...] essa alternância entre sublime e abjeto que caracteriza a parte obscura de nós mesmos no que esta tem de mais herético, mas também de mais luminoso: uma subjugação voluntária concebida como expressão da mais elevada das liberdades. (ROUDINESCO, 2008, p.17)

A mulher, dentro deste contexto, passa a ser aquela cuja personalidade transita entre o bem e o mal com muita facilidade e este padrão de beleza meduseia reverbera por muitas damas descritas em versos e prosa.

Portadora de uma beleza doentia e misteriosa, fulgura Salomé, a dona de uma sequência significativa de obras de arte feitas em sua homenagem, como pôde perceber, em 1912, Maurice Krafft que, possivelmente, acreditou "ter contado 2.789 poemas glorificando Salomé." (BRUNEL, 2005, p. 808). Tema recorrente da literatura universal, Salomé ora carrega em si a clássica contradição das 
mulheres carneirianas, que representam as companheiras e a presença que equilibra; ora as demoníacas que, por capricho, destroem a vida de seus homens, em decorrência de suas ações. Salomé é dona de todo um capítulo de Às avessas, de J-K Huysmans, que coloca sua personagem des Esseintes contemplando um quadro da mesma, pintado por Gustave Moreau. A personagem se recorda das inúmeras vezes que buscava a Bíblia para ler e reler o que S. Mateus, S. Marco e S. Lucas escreviam sobre ela. Des Esseintes chega a uma descrição bastante adequada ao papel de Salomé para a geração de escritores decadentes. Ela é:

[...] de alguma maneira, a deidade simbólica da indestrutível Luxúria, a deusa da imortal Histeria, a Beleza maldita entre todas eleitas pela catalepsia, que the inteiriça as carnes e lhe enrija os músculos; a Besta monstruosa, indiferente, irresponsável, insensível, a envenenar, como a Helena antiga, tudo quanto dela se aproxima, tudo quanto a vê, tudo quanto ela toca. (HUYSMANS, 1987, p. 86)

A Salomé imortalizada em soneto de mesmo nome por Sá-Carneiro, assim é descrita:

Insônia roxa. A luz a virgular-se em medo, Luz morta de luar, mais Alma do que a lua... Ela dança, ela range. A carne, álcool de nua, Alastra-se pra mim num espasmo de segredo...

Tudo é capricho ao seu redor, em sombras fátuas... $\mathrm{O}$ aroma endoideceu, upou-se em cor, quebrou... Tenho frio... Alabastro!... A minha Alma parou... E o seu corpo resvala a projetar estátuas...

Ela chama-me em Iris. Nimba-se a perder-me, Golfa-me os seios nus, ecoa-me em quebranto... Timbres, elmos, punhais... A doida quer morrer-me:

Mordoura-se a chorar - há sexos no seu pranto... Ergo-me em som, oscilo, e parto, e vou arder-me Na boca imperial que humanizou um Santo...

Lisboa, 3 de novembro de 1913. (SÁ-CARNEIRO, 1995, p.77) 
Dona de um magnetismo, Salomé faz com que o eu do poema se sinta passivo mediante seu poder de sedução. A primeira estrofe é introduzida pela frase "Insônia roxa", que nos remete a um universo de luto e mistério, que se segue pela descrição de sua dança e seu efeito embriagante, num eu que se vê "num espasmo de segredo...". Nada é capaz de permanecer incólume perante a mulher que tem um corpo "álcool de nua", tamanha a sua capacidade de embriagar e, que produz efeitos como endoidecer os aromas, upar as cores, produzir frios, paralisar almas. Ela tira a vida, a alegria, ela paralisa, mata. O eu lírico se vê aprisionado por aquela que fez o improvável, ela "humanizou o Santo", ou seja, se até João Batista se viu apaixonado por ela, qualquer outro mortal o ficaria.

"Salomé", cujo nome vem do hebraico e significa "paz", perde seus ares de pacificadora e ganha ares de ardilosidade. $\mathrm{O}$ " $\mathrm{S}$ " de seu nome nos remete às curvas "art-nouveau" e à capacidade de chegar em silêncio, de seduzir lentamente, como bem fazem as serpentes. Ela tem sua história marcada pela fraqueza dum tetrarca que, ao desconhecer a força e o poder da palavra, promete a ela tudo que quisesse em troca de uma dança. Musa dos decadentes artistas do final do século XIX, Salomé personifica a arte deste período. Ela, nesta esfera, é a encarnação da beleza, do mistério, da sensualidade e do apego ao uso da palavra e suas possibilidades polissêmicas. Ainda que Salomé possa ser vista como uma mulher mimada e caprichosa, ela não mente, não engana, a única coisa que pede é aquilo que Ihe prometeram. Não é ela quem erra, ela induz ao erro. Foi o mau uso da palavra, feito por Herodes, que condenou João Batista à morte e não a sensualidade da dança de Salomé, ainda que, historicamente, ela seja vista como o "[...] modelo da Mulher instrumento do Demônio e exemplo das funestas consequências das danças lascivas, já proibidas por um Concílio de serem levadas em lugares sagrados." (BRUNEL, 2005, p. 808).

Em outros momentos da obra de Sá-Carneiro temos a presença de mulheres que, em muito, se parecem com a malévola Salomé. A mulher, apenas nomeada como Americana, de A confissão de Lúcio, despertou na personagem principal da narrativa as sensações de horror e medo, misturadas 
com prazer, conforme descreveu Praz. Ela foi vista como alguém dotada daquilo que Lúcio intitula como "[...] misteriosamente belo" (SÁ-CARNEIRO, 1995, p.354) e o sentimento por ele tido neste momento foi "[...] de medo - um medo semelhante ao que experimentamos em face do rosto de alguém que praticou uma ação enorme e monstruosa" (SÁ-CARNEIRO, 1995, p.355). Assim, vemos uma constante mistura entre o perfil feminino e ações monstruosas, ora feitas, ora despertadas por mulheres sensuais e misteriosas. Elas carregam em si as joias, os véus, os perfumes, as flores de lírio e lótus, o culto à noite e à Lua, a valorização da serpente. Estas mulheres são, em sua maioria, aquelas que, como Salomé, fazem qualquer homem perder a cabeça por elas.

Fisicamente donas de uma beleza singular e bizarra, eram magras, de aparência doente, tinham mãos longas e brancas, além de terem o tom enigmático que marca boa parte da obra do autor, como no poema "A inigualável", que pertence a Indícios de ouro.

\author{
$\mathrm{Ai}$, como eu te queria toda de violetas \\ E flébil de cetim... \\ Teus dedos longos, de marfim, \\ Que os sombreassem joias pretas... \\ E tão febril e delicada \\ Que não pudesses dar um passo - \\ Sonhando estrelas, transtornada, \\ Com estampas de cor no regaço... \\ Queria-te nua e friorenta, \\ Aconchegando-te em zibelinas - \\ Sonolenta, \\ Ruiva de éteres e morfinas...
}

Ah! que as tuas nostalgias fossem guizos de prata -

Teus frenesis, lantejoulas;

E os ócios em que estiolas,

Luar que se desbarata...

Teus beijos, queria-os de tule,

Transparecendo carmim -

Os teus espasmos, de seda...

- Água fria e clara numa noite azul,

Água, devia ser o teu amor por mim... 
Lisboa, 16 de fevereiro de 1915.

(SÁ-CARNEIRO, 1995, p.95)

A mulher desejada pelo eu lírico é uma mulher envolta num ar de mistério, de riquezas, luxo, drogas, anormalidades, que deveria vir coberta de "violetas"; não as flores, mas sim a tonalidade da cor, desta forma, ela deveria estar arroxeada e envolta em cetim, tecido frio e fluido, que estimula o toque, mas ao mesmo tempo, o eu a desejava nua, apenas coberta por peles. O estado físico da mulher deveria beirar a falta de autonomia, pois melhor seria se ela perdesse a capacidade de andar de tão fraca e, acometida de espasmos, fosse-lhe dada a condição de oferecer a ele um amor cujo tom fosse de "água".

Mais que a descrição de um perfil, temos aqui também uma categorização dessa mulher. A dama descrita é alguém "inigualável", ninguém consegue ser igual a ela, não apenas porque ela é a dileta do eu lírico e, portanto, naturalmente, seu objeto de desejo, mas também pelo exotismo que ela tem, sendo a representação de um padrão feminino almejado pelo eu. A singularidade dela está na falta de cor, de saúde, de viço, o que nega uma concepção de Belo ainda que levado em conta "[...] que aquilo que é considerado belo depende da época e da cultura" (ECO, 2004, p.14).

As mãos femininas na obra de Sá-Carneiro são, muitas vezes, alvo de descrições e os dedos descritos com primazia, pois, muitas vezes, estes são os responsáveis pelos toques de um amor que, na obra de Sá-Carneiro, é inalcançável. No poema "Elegia", de Indícios de Ouro, temos "Ó dedos longos que toquei, mas se os toquei, desapareceram..." (SÁ-CARNEIRO, 1995, p.96), em "A inigualável" são "dedos longos de marfim" cobertos por "joias pretas". A roxidão dos dedos da mulher é a mesma que aparece em "Insônia roxa." (SÁCARNEIRO, 1995, p.77) de Salomé, nos "Caprichos de lilás" (SÁ-CARNEIRO, 1995, p.94), de "Anto", entre tantas outras menções à cor, que remete ao mundo espiritual, ao mistério, ao Belo e à arte.

A mulher de "A inigualável" era "Ruiva de éteres e morfinas...", assim como a Americana, de A confissão de Lúcio, que era: "Uma criatura alta, magra, de 
um rosto esguio de pele dourada - e uns cabelos fantásticos, de um ruivo incendiado, alucinante. A sua formosura era uma destas belezas que inspiram receio." (SÁ-CARNEIRO, 1995, p.354). Ainda na mesma obra, durante o episódio da festa, três dançarinas surgem para um espetáculo. Lúcio se encanta com a terceira que, não estranhamente, é descrita como "[...] uma rapariga frígida, muito branca e macerada, esguia, evocando misticismos, doenças, nas suas pernas de morte - devastadas." (SÁ-CARNEIRO, 1995, p.363).

Envolvia-a uma túnica branca, listada de amarelo. Cabelos soltos, loucamente. Joias fantásticas nas mãos; e os pés descalços, constelados... [...] Entretanto, ao fundo, numa ara misteriosa, o fogo ateara-se... (SÁ-CARNEIRO, 1995, p. 363364)

Além do perfil fatal que as mulheres apresentavam, nenhuma delas é descrita com família, não são mães, não são mostradas fazendo trabalhos domésticos, elas eram ligadas às artes, eram aquilo que se designa como "bas-blue", pois encarnam a mulher pedante, artista, mas completamente blasé.

Assim como a "Salomé" pintada por Gustave Moreau, que abre este capítulo, as mulheres carneirianas eram bastante ornamentadas, repletas de pedrarias e metais, bem ao gosto dos decadentistas franceses que tantas vezes serviram de inspiração a Mário de Sá-Carneiro. Em "A inigualável” os dedos cobertos com "joias pretas". A Americana tinha "[...] nos braços serpentes de esmeraldas [...]" (SÁ-CARNEIRO, 1995, p.361), sua roupa era composta por uma "[...] malha de fios metálicos [...]"(SÁ-CARNEIRO, 1995, p.360), — os mesmos fios que aparecem nas meias de Marta, assim descrita:

[...] estava linda essa noite. Vestia uma blusa negra de crepe-dachina, amplamente decotada. A saia, muito cingida, deixava pressentir a linha escultural das pernas, que uns sapatos muito abertos mostravam quase nuas, revestidas por meias de fios metálicos, entrecruzados em largos losangos por onde a carne surgia... (SÁ-CARNEIRO, 1995, p. 387-388) 
Nos cabelos enrolados desordenadamente estavam "[...] pedrarias que constelavam aquelas labaredas em raios de luz." (SÁ-CARNEIRO, 1995, p. 360). A última dançarina tinha "[...] joias fantásticas nas mãos." (SÁCARNEIRO, 1995, p. 363).

Associado ao perfil da mulher "febril e delicada", que estava "nua e friorenta", todas altas, magras, ruivas e com um certo ar de mistério e doença, artistas, elas têm em comum a dança. A dança feita por mulheres fatais tem seu ápice no episódio da festa descrita em A confissão de Lúcio. A entrada na sala em que se fez a festa era feita por um ascensor em que Lúcio e Gervásio VilaNova foram empurrados e colocados abruptamente n"uma sala elíptica cujo teto era uma elevadíssima cúpula rutilante, sustentada por colunas multicores em mágicas volutas." (SÁ-CARNEIRO, 1995, p.360). A entrada na sala era controlada e apenas aqueles que portavam um convite eram encaminhados ao ascensor, ou seja, poucos eram os elevados, os escolhidos para presenciarem o "espetáculo assombroso" (SÁ-CARNEIRO, 1995, p.360). Na sala, havia a presença de um palco e de uma "larga piscina semicircular, cheia de água translúcida" (SÁ-CARNEIRO, 1995, p.360). O movimento da dança parece representado pela própria forma das coisas. Tudo sugere movimento: elipses, colunas volutas, piscina semicircular. A ideia circular que remete à serpente desperta a sensação de sedução, de aproximação, de que a proposta da anfitriã era a de envolver, de atrair seus convidados para um momento definido por Lúcio como uma "orgia da carne espiritualizada em ouro!" (SÁ-CARNEIRO, 1995, p.361). Até mesmo Lúcio, um homem das artes e da boemia, confessou, ao adentrar na grande sala "tive medo...recuei..." (SÁ-CARNEIRO, 1995, p.361). O turbilhão de sensações, despertadas pela combinação de luzes coloridas, música e incensos, concedia à sala uma cena que possibilitava o alcance do "momento luminoso" com a apoteose promovida pelas danças. Num cenário pagão, repleto de artistas prontos para o espetáculo, a ideia de deificação fica mais evidente, com o profano tomando ares de sagrado. Eis que as mulheres surgiam: 
[...] vinham de tranças soltas - blusas vermelhas Ihes encerravam os troncos, deixando-Ihes os seios livres, oscilantes. [...] um cinto de carne nua onde se desfilavam flores simbólicas.

As bailadeiras começaram as suas danças. Tinham pernas nuas. Volteavam, saltavam, reuniam-se num grupo, embaralhavam os seus membros, mordiam-se nas bocas... (SÁ-CARNEIRO, 1995, p.362)

O bailado das moças se encerra com a aparição da última bailarina cuja apresentação foi chamada de "Orgia do Fogo", esta "[...] numa ara misteriosa, o fogo ateara-se..." (SÁ-CARNEIRO, 1995, p.364).

Quimérico e nu, o seu corpo sutilizado, erguia-se litúrgico entre mil cintilações irreais. Como os lábios, os bicos dos seios e o sexo estavam dourados - num ouro pálido, doentio. E toda ela serpenteava em misticismo escarlate a querer dar-se ao fogo... (SA-CARNEIRO, 1995, p.364)

Contrariamente ao provável, nenhuma das pessoas que assistia ao espetáculo interferiu no processo, a moça tinha seu corpo em chamas e todos assistiam calmamente. Ela continuava sua performance, como se a dor não a atingisse. "Então, numa última perversidade, de novo tomou os véus e se ocultou, deixando apenas nu o sexo áureo - terrível flor de carne a estrebuchar agonias magentas..." (SÁ-CARNEIRO, 1995, p.364). Não demorou muito e aconteceu a "apoteose".

Toda a água azul, ao recebê-la, se volveu vermelha de brasas, encapelada, ardida pela sua carne que o fogo penetrara... E numa ânsia de extinguir, possessa, a fera nua mergulhou... Mas quanto mais se abismava, mais era lume ao seu redor...

...Até que, por fim, num mistério, o fogo se apagou em ouro e, morto, o seu corpo flutuou heráldico sobre as águas douradas tranquilas, mortas também... (SÁ-CARNEIRO, 1995, p.364)

A morte espetacular da bailarina provocou reações como a de mulheres que "debatiam-se em ataques de histerismo; homens, de rostos congestionados, tinham gestos incoerentes..." (SÁ-CARNEIRO, 1995, p.364). Aos protagonistas coube o silêncio: "Esmagados, aturdidos, cada um de nós voltou para sua 
casa..." (SÁ-CARNEIRO, 1995, p.364). Não é citada uma única palavra sobre qualquer tipo de implicação legal à morte da moça. $O$ tratamento dado é de uma espécie de morte espetacular e, portanto, neste contexto, não cabia nenhum tipo de punição ou cerceamento.

Segundo Roudinesco (2008), a ideia de sacrifício, da imposição da dor no próprio corpo, a que hoje também podemos chamar de perversidade, já foi chamada de sacrifício, em nome da demonstração de uma fé. Jó introduz o princípio do sofrimento como forma de heroísmo. A mutilação, a doença, que se originou em Jó como símbolo da purificação pelo sofrimento, foi cultuada na Idade Média e, posteriormente, retomada pelos decadentistas.

Liduína de Scheidam (1380 - 1433) teve uma vida de negação ao destino traçado pelo pai de casá-la. Negando essa vida, a jovem, "durante 38 anos, levou a vida de uma grabatária, impondo a seu corpo terríveis sofrimentos: gangrena, epilepsia, peste, fratura dos membros." (ROUDINESCO, 2008, p.27). "Como Jó, viveu numa tábua coberta de esterco, amarrada a uma correia de crina que fazia de sua pele uma chaga purulenta." (ROUDINESCO, 2008, p.27). Após ser acusada de heresia, foi marcada com estigmas. Em 1890, foi canonizada pelo Papa Leão XIII, e despertou enorme curiosidade em J-K Huysmans, que escreveu sua biografia e cultuou esse padrão de quem se entrega a sacrifícios em prol de uma ideia maior.

A demonstração de dor e devoção, que Jó e Liduína apresentam em nome de seu Deus cristão, é exatamente o mesmo princípio apresentado pelas mulheres carneirianas que se entregam em sacrifício em nome da arte. Cada qual, dentro de suas crenças e devoções, cultua e se entrega à dor, ao flagelo e à morte, crendo estar a serviço de um bem maior: ou a Deus ou a Arte.

A palidez de Salomé, seu ar de doença e sua dança são as marcas desta "mulher fatal", pois assim é sua presença na vida dos homens que por ela se encantam. Aqueles que caem em suas garras, invariavelmente conhecerão a dor, a doença e talvez até mesmo a morte. A fatalidade do encontro se realiza pelas consequências desastrosas que estas mulheres causam na vida 
daqueles que com elas se relacionam. João Batista, Herodes, Lúcio, Ricardo são todos desgraçados e têm suas trajetórias de vida alteradas pelo encontro. O que poderia ser apenas um momento de sedução e encantamento pode significar a prisão perpétua, a morte, a culpa e a dor das consequências de atos desejados.

A tentativa de possuir esta mulher serpente, como pintou Gustave Moureau, repleta de pedrarias, vestida a oiro, com sua postura altiva e autoritária, que é capaz de fazer com que a cabeça de João Batista Ihe venha até as mãos, pode ser a porta de entrada ao mundo sacralizado das rupturas, repleto de morte e comportamentos perversos. 
CAPÍTULO 3 - O CAMINHO DAS RUPTURAS: A MORTE, O SUICÍDIO, O CRIME, AS PERVERSÕES E O VÍCIO

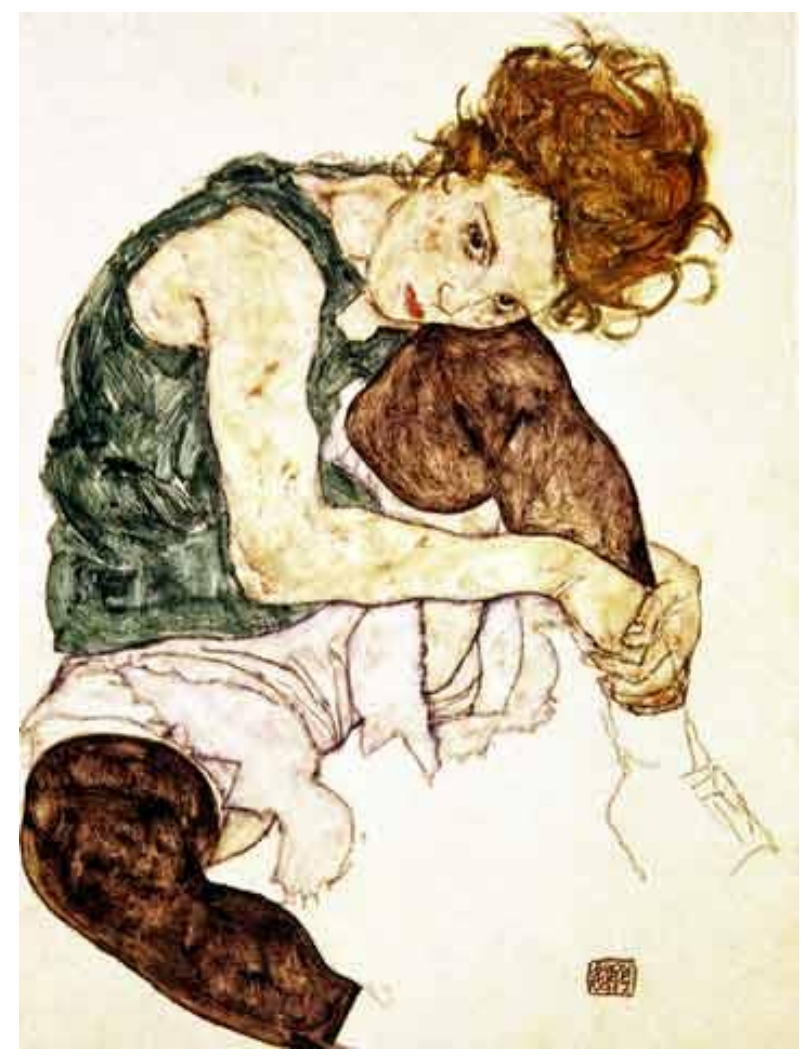

SCHIELE, Egon. Mulher sentada com a perna esquerda dobrada.

"[...] gaza, meu amiga, gaza e nãa julgues... gaza, diga-te eu, alandana à natureza a cuidada de te maver à sua vantade, e à eternidade a de te punir.”

Marquês de Sade, Os infartúnias da uirtude. 


\section{1 - A morte, o suicídio e o crime}

Um dos pontos de intersecção mais fortes entre poemas, contos e outros escritos de Mário de Sá-Carneiro é sua insistente recorrência na temática da morte. Ela aparece, se não em todos, em quase todos os seus textos e, muitas vezes, é dado a ela o mesmo tratamento destinado ao assunto, no poema "Fim", que encerra o livro Últimos poemas.

\footnotetext{
Quando eu morrer batam em latas,

Rompam aos saltos e aos pinotes,

Façam estalar no ar chicotes,

Chamem palhaços e acrobatas!

Que o meu caixão vá sobre um burro

Ajaezado à andaluza...

A um morto nada se recusa,

Eu quero por força ir de burro.
}

O eu lírico do poema reflete sobre seus desejos para a hora de seu passamento e, neste momento, uma possível melancolia, medo do desconhecido ou remorso por alguma ação não vivida são completamente ignorados e é dado lugar a uma manifestação de tranquilidade e aceitação da morte. Ela vista aqui desta forma, é tida como algo distante daquilo que o senso-comum costuma evocar, pois o eu lírico manifesta o desejo de que "batam em latas", que "chamem palhaços e acrobatas" para celebrar sua ida. Desta forma, ele não apenas não se lamenta, como festeja o feito.

No poema em questão temos, associada à morte, a ironia carneiriana, deflagrada pela maneira com que ele quer que sua ida seja celebrada. $\mathrm{O}$ eu não pede por uma canção ou por rezas, ou pela leitura de um texto, por exemplo, ele pede pela presença de um circo. O pedido, de caráter eminentemente bufão, concilia a presença do circo com um burro ornado e é esta a imagem que ele pretende perpetuar em sua despedida. Embora possamos ver este poema como uma manifestação pejorativa do reconhecimento da identidade ou de uma derradeira autoironia, ou ainda, de 
como o "eu" consegue, na tentativa de marcar seu último instante, mostrar-se como um ser digno de chacota, de troça; ele também pode ser visto como uma maneira de olhar a morte, pois aqui, nesta perspectiva, ela perde seu peso de lamento ou tragédia e ganha a possibilidade de representar uma libertação.

Este tipo de reação perante a morte é, segundo Heidegger (2011), o momento da plenitude humana. Ou seja, para o autor, é o encontro do eu com sua individualidade, pois, na hora da morte, não há representações, ou necessidades exteriores, ela é o único momento em que o homem encontra a plenitude.

A presença da morte se mostra com diferentes faces na obra de Sá-Carneiro. Ora mata-se ao outro e temos uma situação de crime; ora a morte aparece em forma de suicídio; ora ela se dá na própria existência diante de personagens que se encontram "mortos-vivos".

O conto "Diários", que introduz o livro Princípio, apresenta um narrador descrevendo em primeira pessoa, através das páginas de seu próprio diário, que vêm datadas de 11 de abril de 1908 a 30 de novembro, seu encontro e relacionamento com uma jovem chamada Elisa. A moça é descrita como uma criatura doente, desenganada e que, devido a isto, não poderia e nem deveria conhecer o amor.

O interesse do narrador pela jovem é imediato, e ele lamenta a condição de saúde dela, revelando que "Se não fosse o seu estado, talvez a viesse a amar. Mas não se ama uma morta... Pobre... pobre rapariga!" (SÁ-CARNEIRO, 1995, p.252). Mesmo posta como uma moça que está "morta", o narrador, contrariamente ao suposto, pela falta de saúde e a consequência que isto costuma conferir à aparência, descreve-a usando o adjetivo "formosa". "E é formosa... formosa de uma formosura etérea, que já não é deste mundo. As faces pálidas, os lábios descorados; mas uns olhos tão negros, tão brilhantes... uns cabelos tão lindos..." (SÁ-CARNEIRO, 1995, p.252). A formosura sublime da morta, sua ausência de cor, de vivacidade, não é impedimento para a realização deste amor, fazendo com que a ideia inicial de não realização 
amorosa, para ela, fosse superada. Sua aparência e seu fim inexorável nada significavam e o envolvimento de ambos aumentou gradativamente. O sadismo deste sentimento é a companhia do narrador. Ele vê na palidez, na doença, na falta de vivacidade da amada, a beleza e questiona em uma das páginas de seu diário se "Poder-se-á amar uma morta?..." (SÁ-CARNEIRO, 1995, p.252). $O$ texto onde registra os dias seguintes aos do último relato nos responde que sim, que é possível, pois em 19 de maio ele escreve: "Amo! Amo pela primeira vez!" (SÁ-CARNEIRO, 1995, p.252) e, diante do fato da doença da moça ser logo constatada e esta não ter grande expectativa de cura, ele sinaliza uma das ideias da poética carneiriana, a de que o amor, a morte e o sofrimento são indissociáveis e que, nesta perspectiva, "Um prazer doloroso é o melhor prazer..." (SÁ-CARNEIRO, 1995, p.252).

O prazer despertado no narrador está justamente na iminência da morte, pois este é um dos fatores que atrai este narrador apaixonado. Mesmo esbravejando "Como sou desgraçado! Ah! como sou desgraçado!..." (SÁCARNEIRO, 1995, p.252) por estar nesta situação, ele não consegue se desvincular, mesmo questionando-se se "Poderá haver algum martírio mais horrível do que o meu?... Amar o impossível, amar a morte!" (SÁ-CARNEIRO, 1995, p.253). Na óbvia resposta à sua pergunta, ele constata que sim, que ele ama a morte, pois a moça é a personificação dessa morte, não fazendo diferença os sentimentos da amada, tampouco o fato de haver ou não consequências outras deste relacionamento.

O narrador, talvez pelo próprio fato de considerar a morte como um momento de plenitude, ou pela dificuldade de se posicionar na condição do outro, não é capaz ou desejoso de mensurar o sofrimento da vítima comparado ao seu, pois sua individualidade, sua dor de amar, ele supõe ser maior que a da própria moça que está destinada ao fim. Ele não menciona a dor dela, mais do que isto até, ele não fala quase nada sobre ela. A mulher amada não existe como um indivíduo, os sentimentos dela não têm espaço na narrativa, ela apenas é o suporte para a manifestação dos sentimentos da personagem, o amor aqui se mostra como um ato egoísta, individualizado. 
A felicidade do casal, registrada nas páginas do diário, se dá apenas durante o período de julho até 21 de setembro, quando é verão em Portugal, mas a presença do outono traz consigo a proximidade do fim, tanto dele quanto dela. A morte de Elisa não apenas a atinge, mas deflagra a morte também do narrador: "Morreu hoje... Era a minha vida... morri também..." (SÁ-CARNEIRO, 1995, p.253). A morte física da namorada despertou “Lágrimas, lágrimas só em vez de beijos..." (SÁ-CARNEIRO, 1995, p.254), e, mesmo em meio a tantos lamentos, ele registra que "A sua morte causou uma certa alegria..." (SÁCARNEIRO, 1995, p.254). Nesta confusão de sentimentos, o fim da moça, em 30 de outubro, desencadeia também o fim do narrador, datado imprecisamente entre 30 de novembro ou 01 de dezembro.

A morte, oriunda da doença, não foi possível de ser freada e mesmo muito jovem, Elisa se foi. Ao ver o amante perder seu objeto amoroso, o leitor põe-se a questionar se o amor dele por ela seria suficientemente grande para levá-lo ao suicídio. Afinal foram aproximadamente sete meses de relacionamento, 0 que, cronologicamente, parece ser pouco para uma atitude tão extremada, como ficou registrado nas linhas finais do texto.

30 de novembro,

Faz hoje um mês...Quero vê-la...quero vê-la!...Quero beijar-lhe a boca...estreitar o seu corpo contra o meu...quero confundir a sua alma com a minha... Quero-a! Quero-a! Vou partir...

Os jornais do dia seguinte anunciavam com efeito o seu suicídio.

(Lisboa, agosto de 1909)

(SÁ-CARNEIRO, 1995, p.245)

Ao que parece não era o amor dele por ela que se mostrava tão grande, mas a sua atração pela morte, que chega ao seu auge pelo suicídio.

O suicídio, segundo Puente (2008), já foi visto de maneiras muito díspares na história da humanidade; ora posto como um desperdício da mão de obra economicamente ativa, o que levava a crer na perda financeira que esse ato 
acarretava; ora visto como ato heroico, como o praticado pelos romanos, que se matavam em defesa da honra da família ou do Estado. Mas, grosso modo, não são essas as maneiras mais apropriadas de percepção do termo ao contexto português do final do século XIX e começo do XX. Muito influenciado pela cultura cristã, o homem português deste tempo desautorizava o suicídio mais por seu apego à tradição religiosa. Se a vida é vista pelo viés de que foi concedida ao homem por Deus, é considerado uma afronta abrir mão de um presente divino deste porte. Visto como um ato de recusa à divindade, suicidarse era um ato tão desconcertante que, ainda hoje, algumas religiões chegam a proibir os rituais fúnebres ao morto.

Segundo Bataille, a morte e o suicídio "[...] têm duplo sentido: de um lado, o horror nos afasta, ligado ao apego que inspira a vida; do outro, um elemento solene, ao mesmo tempo assustador, nos fascina, introduzindo uma inquietação suprema." (1987, p.42). O fascínio é a palavra-chave no que tange ao suicídio. A simpatia pelos suicidas aparece claramente nas páginas de "Incesto", quando temos:

[...] você não considera o suicídio uma covardia?

Mas de forma alguma! Acho até que um suicida é uma criatura de enorme coragem. Escusam de me interromper... Sei muito bem que um suicida é um desertor: a existência tornara-se-lhe impossível; ele fugiu-lhe. Perfeitamente. No entanto, para fugir, teve que praticar um ato muito mais violento - logo, muito mais corajoso - do que praticaria se continuasse a viver. Se continuasse vivo, conformava-se no fim das contas com a lei comum. "A vida é um sofrimento eterno", sujeitava-se. Mas ele não se sujeitou, morreu às suas próprias mãos, isto é: revoltou-se. Ora, meus amigos, "revolta" foi sempre sinônimo de audácia, de coragem, de energia.

Os suicidas! Ah! com que entusiasmo os admiro, como os respeito! Eles realizam aquilo que quiseram. Eis sua grande superioridade. Valem bem mais do que eu, que tenho tanto desejo e nunca serei capaz de despejar um revólver sobre o meu crânio. Quem vive bocejante, lazeirento como eu vivo, e continua a viver, não é só um covarde - é um miserável. (SÁ-CARNEIRO, 1995, p.327-328)

Num manifesto contra a vida banal e fazendo apologia ao suicídio, a morte provocada representa não o fim da vida apenas, ela vem com outras conotações mais importantes. Uma delas é o fato de se crer que, por meio do 
suicídio, é possível atingir o ápice da liberdade, pois ele é uma decisão de revolta solitária e sua execução se dá, na maioria das vezes, sem nenhuma contribuição alheia, e denota uma ação perante a alienação da qual o indivíduo necessita para suportar tantas pressões da sociedade. Cabe ao suicida apenas a preparação e execução da ação, a ele não recairá a, talvez, pior parte do ato: o cuidado póstumo do corpo.

O corpo morto nos remete à ideia da putrefação, aquilo que Bataille chama de "horror da decomposição" (BATAILLE, 1987, p.55), do envelhecimento, justamente um ponto em que os decadentes têm grande dificuldade de aceitação, daí a insistência em manter uma vida sempre jovem, levando alguns ao suicídio pela intolerância de ter que passar pelo ônus da velhice. 0 decadente não teme a morte, ele teme envelhecer.

A opção por não ser vítima de uma morte natural é clara para a alma destas personagens, pois elas não toleram a vida adulta com suas atividades castradoras e banais, a depreciação física com a perda da beleza e do vigor, da vivacidade, da disposição para a boemia, além de ter que aceitar as muitas mudanças que o tempo impõe. Morrer naturalmente é algo esperado e aceito, segue a ordem natural da vida, ela apenas significa uma ruptura. Rompe-se com os vínculos de amizade, de família, de trabalho e etc, mas não é catastrófica e, na maioria das vezes, sequer traumática. A morte natural é, como seu próprio nome representa, uma consequência da vida, algo previsto e aceitável, está dentro de uma esfera do previsto e nada que seja absolutamente natural é bom para os decadentes. Daí uma das outras razões para o culto da morte suicida porque, dependendo de como ela é feita, ela pode ser até espetacular, artificial, ou até mesmo teatral. A morte espetacular é reveladora e retira a possibilidade da entrada do homem na vida banal; com este tipo de ação, mais uma vez, ele busca uma atitude que lhe ofereça autenticidade.

"A modernidade deve manter-se sob o signo do suicídio, selo de uma vontade heroica, que nada concede a um modo de pensar hostil." (BENJAMIN,1989, p.74-75), e, baseados nesta ideia, percebemos que o suicídio aparece em 
quase todos os poemas de Dispersão, que reúne em seu próprio título a ideia de esvair-se, dispersar-se, suicidar-se. Composto por uma sequência de doze poemas, dentre eles, "Partida”, "Escavação”, “Intersonho”, “Álcool”, "Vontade de dormir", "Dispersão" e "A queda", a temática está, majoritariamente, voltada ao pessimismo, a um estado de transe, turvo, de não realização e de suicídio.

Fios d'ouro puxam por mim A soerguer-me na poeira Cada um para o seu fim, Cada um para o seu norte..

- Ai que saudade da morte...

Quero dormir... ancorar...

Arranquem-me esta grandeza!

- Pra que me sonha a beleza, Se a não posso transmigrar?...

Paris, 6 de maio de 1913 (SÁ-CARNEIRO, 1995, p.60)

Composto por nove versos intercalados por três linhas de reticências, "Vontade de dormir" apresenta um eu lírico que se mostra em um momento de angústia, fragmentação e submissão. Dotado de uma incapacidade de se mostrar agente de sua história, ele se vê puxado para lados opostos desarmonicamente. Sua passividade se dá porque não é ele quem age, ele é movido por "fios de ouro" que o levam para aquilo que the é de interesse: "Cada um para seu norte...". A passividade do eu é brevemente interrompida pela fala em discurso direto de que ele sente "saudades da morte...". A saudade ali posta deflagra a intimidade que ele tinha com ela, como se fosse possível sentir saudade de algo que não se tenha vivido, como a experiência com a morte. Enfastiado pela não possibilidade de fazer a obra de arte perfeita, ele sabe ser um escolhido pela sua capacidade criadora, sabe ser o dono d"esta grandeza", mas percebendo 
sua dificuldade de fazê-la fluir como gostaria, de fazer-se "transmigrar", sua saída acaba sendo optar por "dormir... ancorar..." Referência explícita à morte, o sono desejado seria o encontro com a calmaria ainda não alcançada. $O$ desejo de "ancorar" é, possivelmente, o fim da marola a que ele estava exposto, é um pedido por terras firmes, por referência, por tranquilidade. Não existe mais a vontade de sair, de navegar, de descobrir o novo, tudo que se sonha é parar, morrer. Receptáculos desta mesma angústia são as sete histórias de Princípio, por exemplo.

Em "A profecia”, terceiro conto do livro, a morte de Antônio Maldonado (nome impregnado pela sonoridade de "mal", de "amaldiçoado"), um poeta que se suicida e deixa seus escritos ao narrador, faz com que ele se sinta na obrigação de esclarecer os fatos que envolveram a morte, por ser "[...] a única pessoa a conhecer a verdade, bem singular por sinal." (SÁ-CARNEIRO, 1995, p.258). A ideia de esclarecer e de dar uma verdade singular nas linhas iniciais do texto mostra a dificuldade de clareza se nos apegarmos apenas aos fatos. Graças ao recurso do mistério, que dá o tom da narrativa, e à certeza do inusitado dos fatos, é necessário tentar esclarecer os acontecimentos. 0 suicídio do colega foi tão enigmático que despertou comentários e fez com que ele entendesse "[...] que é tempo de destruir lendas que poderiam ofuscar a glória do seu nome - para explicar o suicídio, falou-se até numa burla resolvi publicar os excertos do seu diário que indicam o motivo que o levou a deixar a vida." (SÁ-CARNEIRO, 1995, p.258). Num tom evidentemente dramático e exagerado, o narrador pontua que Maldonado era dono de uma vida marcada pela "glória" e que seu nome, equivocadamente, estava envolvido em "lendas" que poderiam macular esta vida brilhante.

A primeira página do diário é datada de 20 de dezembro de 1907, inverno em Portugal, e os relatos são de um medo brutal perante a possibilidade da morte, não pelo seu caráter de finitude, mas pelo desconhecido que a ela atribuímos: "EU TIVE SEMPRE MUITO MEDO do desconhecido [...] A morte é o desconhecido. Não me importa morrer. Ah! mas como tenho medo da morte!..." (SÁ-CARNEIRO, 1995, p.258). Em 10 de junho, Maldonado comenta a morte de seu alfaiate: "Esse não teve medo. Ele próprio foi ao seu encontro." (SÁ- 
CARNEIRO, 1995, p.259). O suicídio visto assim é um ato de coragem, de enfrentamento do desconhecido, visão oposta a do senso-comum, que vê neste tipo de ação algo que denota covardia perante a vida. $O$ entusiasmo com - comando de sua existência é tão grande que Maldonado escreve ironicamente seus planos futuros: "20 de novembro. O próximo Verão passá-loei todo na Suíça. Preciso de ar... Que digo? O próximo Verão!?... Eu morrerei na Primavera... Ah! Ah! Ah!" (SÁ-CARNEIRO, 1995, p.259). Quase dois anos depois, ele registra "15 de janeiro de 1909. Afinal já não penso na morte. Não penso nem a receio..." (SÁ-CARNEIRO, 1995, p.259). A morte não lhe é mais uma desconhecida, durante estes quase dois anos, ele foi perdendo seu medo e lidando com sua proximidade de maneira tranquila, sem receios a tal ponto que chegou a afirmar: "Um secreto pensamento mo afirma: morro de hoje a cinco dias! Cinco dias... cinco dias..." (SÁ-CARNEIRO, 1995, p.260).

A certeza de sua morte é o título do conto "Profecia", o que parece irônico porque, profetizar uma ação em que você é o agente não é um feito, o que nos faz crer que o suicídio, neste caso, é apenas a manifestação da morte. É como se o suicida não tivesse o poder de fazer a ação, ela é tida como uma manifestação autônoma e, por isso, a possibilidade de profetizá-la. Ele sabe que um dia ela virá buscá-lo, a diferença e o que dá o caráter profético é que, no caso dele, ele sabia quando.

12 de abril (manhã)

\footnotetext{
Morro hoje! Morro, e não sei como nem a que hora. Eis-me à espera da morte, sentado numa cadeira, fechado no meu quarto, tal como na estação do caminho de ferro muita vez esperei um amigo.

Não ouso fazer um movimento. Tenho sede... não me atrevo a beber! Tenho fome... não me arrisco a comer! Ela pode estar na água, na comida... Ela está por toda parte. Onde estará agora? Donde me espreitará?

Mas eu não quero! Não quero! Não quero!... Como é bela a vida... que linda manhã de Primavera! Brilha tanto o sol...

O sol! sol!... A vida! A vida!... (SÁ-CARNEIRO, 1995, p.260)
}

A passividade do poeta perante o momento é grande. Ele se senta, espera e, conforme o tempo vai passando, começa a temer ações simples do dia a dia, como comer e beber água. Tratada na terceira pessoa, a morte é personificada 
e parece estar à espreita, pronta a pegá-lo a qualquer momento. Como não suportava a angústia da espera e o medo do desconhecido a assombrá-lo, ele resolve pôr fim à situação.

Esperei-a vinte e três horas: ainda não veio; vou ao seu encontro. Talvez não chegasse hoje...Mas eu prefiro morrer a esperá-la por mais tempo. Prefiro tudo, tudo, a este pavor, a este calafrio de medo...

(Camarate, setembro de 1909)

(SÁ-CARNEIRO, 1995, p.261)

A profecia se dá pela própria ansiedade. Não sendo capaz de esperá-la, ele vai ao encontro da morte. O mesmo encontro foi feito por Lourenço Furtado, o suicida de "Páginas de um suicida", quarto conto de Princípio.

Usando-se do mesmo expediente de "Diários", "Páginas de um suicida" também é a transcrição de um diário com os registros dos momentos finais de Lourenço Furtado e, neste caso o suicídio é tão bem visto que chega a ser comparado à descoberta de Cristóvão Colombo:

Serei como um arrojado descobridor de mundos: Colombo descobriu América; Vasco da Gama, a Índia... eu descobrirei a Morte!... Uma diferença haverá apenas: eu guardarei minha "descoberta" só para mim; eles fizeram presente das suas à humanidade... Foram generosos. Serei egoísta ...

(SÁ-CARNEIRO, 1995, p.262)

A morte, desta maneira descrita, é vista como um "local" a ser descoberto, e que caberá a um herói tal feito. Morrer daria a ele o "status" de descobridor e a certeza de estar fazendo algo sensacional, pois "Não há dúvida: a única coisa interessante que existe atualmente na vida é a morte!..." (SÁ-CARNEIRO, 1995, p.263).

Se, como vimos anteriormente, a morte imposta a si não é um problema, não há razão alguma para fazer diferença à imposta aos outros. Matar é visto com 
a mesma naturalidade que morrer e, nesta esfera, adentramos a mais uma face do mundo dos perversos. O mandamento cristão "Não matarás!" não cabe ou não faz sentido neste contexto e, contrariamente a isso, existe até mesmo uma simpatia pelos criminosos, loucos e outros tipos humanos pouco admirados. $O$ narrador de "Ressurreição" assim afirma:

De resto o meu amor não ia só aos doidos, àqueles que tiveram o gênio de arder, de dar o grande salto, de mergulhar o abismo: não; numa violência enclavinhada descia também a todos os criminosos - assassinos, ladrões, incendiários - a quantos foram capazes de uma evasão, duma revolta, duma ânsia - que nunca se domaram, que sempre estrebucharam... E um desprezo igual a esse amor, ele carregava aos outros - os castrados: a gente digna e sensata, os que nunca tiveram um gesto de cólera, que nunca ousaram defender ninguém - e falam baixo, e ouvem sempre bem atentos os seus interlocutores - e não vibram entusiasmos infantis, ternuras frívolas - e são justos, honrados, sinceros, coerentes em todos os seus atos!...

Malandros! Malandros!...(SÁ-CARNEIRO, 1995, p.545)

Passagem simbólica e representativa, o narrador aponta seu "amor" àqueles que foram capazes "de dar o grande salto, de mergulhar o abismo", por meio "de uma evasão, duma revolta, duma ânsia", tais quais as ações aludidas nos capítulos um e dois desta tese, onde se apontam os recursos usados para a criação de uma nova realidade e a busca incessante por momentos significativos. Na mesma proporção em que o narrador ama os perversos, ele despreza os "castrados", os ponderados. A educação é violentamente repudiada, ele não tolera "a gente digna e sensata" os "que nunca tiveram um gesto de cólera" os que "falam baixo", os que "ouvem sempre bem atentos", os que "são justos, honrados, sinceros, coerentes". Ele despreza tudo aquilo que é altamente valorizado na sociedade portuguesa da época.

Por meio da busca dos momentos luminosos, de uma vida que represente a liberdade e a possibilidade de sair do tédio, fica cada vez mais próxima a possibilidade de se perder a conexão com as leis balizadas no plano factual. Assim, não há culpa que recaia a quem assim pensa. A questão da culpa, quando se é um assassino, se dilui na medida em que este considera que o 
presente simplesmente não existe. Temos aqui, o crime sendo possível pela evasão do mundo real almejado pelos decadentes em associação com a busca pelo "momento luminoso", não cabendo o temor às consequências possíveis a qualquer ação.

Rosset aponta que a evasão do presente é que garante a imputabilidade do criminoso, pois:

[...] o presente é justamente o que não é percebido, invisível, insuportável; e é de muito boa fé que o assassino garante à polícia que não matou: porque o crime ocorreu no presente - eu não estava lá. O passado e o futuro sempre estarão lá para apagar o imperceptível e insuportável brilho do presente. (ROSSET, 2008. p.68)

Sem o medo de ser punido - ou de sofrer as consequências de maneira mais séria - o assassino desfruta de um deleite na morte. Ele a apresenta com glamorização e sua prática é vista como fonte de prazer e, portanto, não deve ser cerceada.

Em "A grande sombra", texto de abertura de Céu em fogo, após um baile de máscaras de Carnaval, o narrador leva uma das mascaradas da festa para um quarto de hotel. "Como se arroxeou então o meu Orgulho, mosqueando-se a esmeraldas! Toda essa carne de segredo ia ser minha! E num espanto de alívio se me evolou por vê-la conservar a máscara - íntegro assim, em ruivo, o Enigma!..." (SÁ-CARNEIRO, 1995, p.439). A mulher misteriosa era seu objeto perfeito de desejo. Ele nada sabia dela, nem seu rosto the era conhecido e, ao perceber que essa atmosfera se quebraria com a retirada da máscara - a consequente quebra do misterioso encanto, ele toma a decisão:

De súbito, desvencilhei-me... Precipitei-me sobre o punhal... Era tempo! O mistério ia desmoronar-se... Ela erguia-se já... Tiraria a máscara, por certo... eu próprio Iha arrancaria... E vê-la... saber quem ela era... ver seus olhos... deixá-la... Não! Não!... Impossível. (SÁ-CARNEIRO, 1995, p.440) 
A luta dele para não conhecer o rosto da mulher amada parece vir envolta a muitas dúvidas, tamanha a quantidade de reticências usadas e a fragmentação das orações. A decisão precisou ser tomada de maneira brusca e sem grande reflexão.

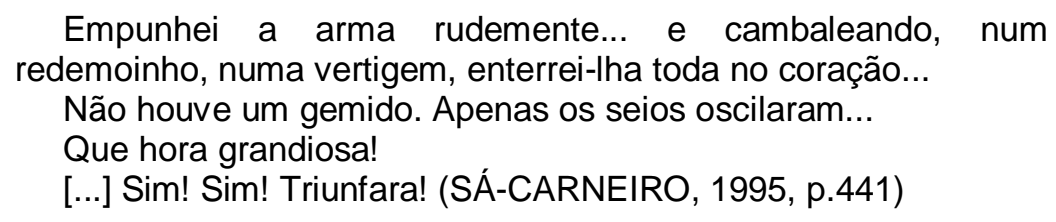

O triunfo a que ele se refere não é o da morte em si, mas o da experiência do momento luminoso proporcionada por ela. É a certeza de que com sua morte a mulher não mais teria sua identidade revelada para ele, bastava sair do quarto e seguir sua vida, mas agora dotado das lembranças da noite gloriosa. Mas, ainda assim, numa eterna busca pela saciedade do tédio, a ação em si não Ihe foi suficiente, dando caminho para mais uma ação do mal, que lhe proporciona o mais puro deleite.

E, num ímpeto, de olhos cerrados, por baixo do loup de seda verde, lacerei furiosamente o rosto dessa mulher que nunca vira: para ninguém mais a poder ver - nem eu mesmo! [...] 442)

Arremessei a arma longe. Fugi... (SÁ-CARNEIRO, 1995, p.441-

A fuga do assassino após lacerar o rosto da vítima não the causou nenhuma consequência. Ele "sonâmbulo", como se tivesse saído diretamente de um sonho, em que nada o pudesse deter, vaga pela cidade.

Guiei-me, sonâmbulo, entre as ruas do parque. [...] Nessa mesma manhã tomei um café expresso na estação Villefranche. Ninguém me impediu o passo...

Ignoro o que deixo atrás de mim... um cadáver pelo menos... Ignoro o que vai suceder... se já correrão a perseguir-me...

Mas o que vale tudo mais em frente da obra a Diamantesmármore que ascendi?... [...]

O triunfo maior: o Triunfo!...

(SÁ-CARNEIRO, 1995, p.441-442) 
Novamente temos o uso da palavra "triunfo", mas não um triunfo qualquer, mas um "Triunfo" grafado com letra maiúscula. $O$ crime na narrativa ocorreu em "Fevereiro de 1909." (SÁ-CARNEIRO, 1995, p.435) e, após a constatação de mais um "momento luminoso", a vida dele não sofre nenhuma sanção. Ele não foi investigado ou descoberto e menos ainda punido pelos seus atos. Em " 3 de fevereiro de 1911." (SÁ-CARNEIRO, 1995, p.442), o narrador comenta que o crime o deslocou da vida banal: "Talhei-me em Exílio." (SÁ-CARNEIRO, 1995, p.442) e ele passou a ter o mistério como uma capa em si, ele "ogivou"-se.

Ora, por essa noite tigrada, no minuto a safiras em que Ihe cravei o punhal - acordei (foi certo) em outro mundo, nasci outra vida: uma vida delgada onde é perpetuamente a mesma estação do ano, onde os instantes existem parados pelo mesmo tempo fora um tempo diverso, inexprimível, sem direção: que não é espaço ou movimento, mas qualquer coisa como um ritmo fluido, constante por transparência vibrátil. (SÁ-CARNEIRO, 1995, p.442)

É como se ele não estivesse mais neste plano, deslocando-se para uma condição diferente da do mundo factual e, neste processo de evasão para outra realidade, se configura o espaço para a realização ilimitada dos desejos humanos.

A certeza da impunidade sempre esteve ao lado do narrador: "Estranha segurança: nunca receei que me descobrissem. Nem pude nunca recear que 0 meu crime fosse algum dia punido. Foi como se nunca o tivesse praticado." (SÁ-CARNEIRO, 1995, p.443). Ele nunca sentiu nenhum tipo de remorso pela ação praticada: "Durmo, ao contrário, densamente - e é esse mesmo peso do meu sono que me aflige e amarfanha." (SÁ-CARNEIRO, 1995, p.449). Além de não se sentir culpado, ele ainda se vê felicíssimo, pois esta foi uma forma de promover a união entre o mistério, a morte e a arte. Ele vê, no momento do assassinato, o triunfo. "Sim! Sim! Triunfara! Até que realizara a minha obra projetara bruma, envolvera névoa, abobadara Sombra... E, a meu redor, a realidade desmoronava-se em gomos negros, cascalhantes..." (SÁCARNEIRO, 1995, p.441). 
Também temos a presença de um crime em "O fixador de instantes", e ele aparece no momento em que há uma dança. A moça que ali aparece é colocada, o tempo todo, lado a lado a um vocabulário de mistério e crime: "requintes perversos", "amor e estrangulamento", "era perversão e loucura", "morta em êxtase", dentre outros. Ele confessa ter, inclusive, medo de tê-la perdido, de que ela tivesse morrido durante a performance. Mas o fato que causa estranheza se dá pela morte dela ser em consequência do que ela suscitara nele: "eu tive medo, ah! sim, medo, que não se erguesse mais, consumado o poema, morta do amor, morta do desejo que em mim suscitara, ou - pelo menos - morta de amor de si mesma..." (SÁ-CARNEIRO, 1995, p. 535).

Um novo mistério se inicia a partir deste instante da narrativa. O narrador em primeira pessoa, nos confessa: "Mais tarde conheci-a. E o sonho continuou... Hoje vivo dela... e ainda não a beijei... e tremo tanto de a beijar... tanto..." (SÁCARNEIRO, 1995, p. 535). O estranhamento nos é causado pela dificuldade que se instaura em saber se tudo que nos fora narrado até então, e as páginas seguintes da história não passam apenas de mais um instante captado pelo narrador e fantasiado a partir dele. Fica a possibilidade polissêmica de se pensar se o que o narrador não foi apenas ao "show" da rapariga e, após tê-lo fixado naquele instante singular, ela tenha vindo a ser mais uma personagem de seu livro/vida.

Ele indica, na última passagem citada, que ela ainda está presente. Presente/passado/futuro se fundem num complexo jogo entre realidade/sonho, verdade/ficção e não somos capazes de determinar se ela está presente porque ainda está viva ou, ainda, se está presente porque se eternizou no ato da fixação.

O desejo por aquela mulher dá sentido a tudo que o narrador fará então. Ele passa a tê-la como aquela que proporciona o "mais dourado instante" (SÁCARNEIRO, 1995, p. 535). Ela torna-se a dona da melhor lembrança que ele tem do passado e, de acordo com o projeto supracitado, o momento vivenciado por eles representa a possibilidade de ir e voltar no tempo, de controlar a vida e 
a morte por meio de sua memória/livro e fazer deste momento de memória o palco para a saciedade das mais variadas perversões, como o sadismo de dilacerar o rosto de uma mulher.

\section{2 - As perversões}

Ao pensarmos numa literatura ligada ao mal, lembramo-nos imediatamente do Marquês de Sade, que se configura como o ícone máximo desse tipo de texto. E, é a partir dele, que Elisabeth Roudinesco, em obra de 2008, começa suas reflexões a respeito daquilo que chama de "A parte obscura de nós mesmos". Juntamente com Plon, em seu Dicionário de Psicanálise, a palavra "perversão" é definida como um:

Termo derivado do Latim pervertere (perverter), empregado em psiquiatria e pelos fundadores da sexologia para designar, ora de maneira pejorativa, ora valorizando-as, as práticas sexuais consideradas como desvios em relação a uma norma social e sexual. (ROUDINESCO \& PLON, 1998, p.583)

Pontuando como suas manifestações "[...] o incesto, a homossexualidade, a zoofilia, a pedofilia, o exibicionismo, a pederastia, o fetichismo, o sadomasoquismo, o travestismo, o voyeurismo, o narcisismo, o autoerotismo, a coprofilia, a necrofilia e as mutilações sexuais" (ROUDINESCO \& PLON, 1998, p.583-584). Não são poucos os exemplos de situações, ações e personagens carneirianos que cultuam essas práticas, algumas vezes coincidindo mais de uma delas, sinalizando um novo tipo de herói para sua literatura. Walter Benjamin (1989) pontua que é Baudelaire quem encontra a denominação "apache" para este novo tipo de herói, ligado a "O espetáculo da vida mundana e das milhares de existências desregradas que habitam os subterrâneos de uma cidade grande - dos criminosos e das mulheres manteúdas [...].". "O apache renega as virtudes e as leis. Rescinde de uma vez por todas o contrato social." (BENJAMIN,1989, p. 78) e, assim, Benjamim pontua que "Os poetas encontram o lixo da sociedade nas ruas e no próprio lixo o seu assunto heroico." (BENJAMIN,1989, p.78). Oriundos das ruas e produto delas, as 
figuras que transitam pelas páginas carneirianas são donas de uma naturalidade ímpar, mediante situações não convencionais. Com relação à sexualidade, à violência e à morte, principalmente, elas se veem inseridas em situações bizarras que se caracterizam por:

[...] um caráter selvagem, bárbaro, polimorfo e pulsional da sexualidade perversa: uma sexualidade infantil em estado bruto, cuja libido se restringe à pulsão parcial. Ao contrário da sexualidade dos neuróticos, essa sexualidade perversa não conhece a proibição do incesto, nem do recalque, nem a sublimação. (ROUDINESCO \& PLON, 1998, p.585)

Sem nenhum tipo de sanção comportamental, sem medo de transgredir e de vivenciar o interdito, o apache carneiriano passa a agir com naturalidade mediante os fatos singulares que vivencia. A transgressão, desta forma, faz com que ele se harmonize com a animalidade de suas ações e, assim, "[...] entramos no mundo da transgressão, formado na manutenção do interdito, a síntese da animalidade e do homem." (BATAILLE, 1997, p.79). O homem, acostumado com sua animalidade, não vê um problema em si e, a denegação de seus atos o coloca cada vez mais próximo e como agente de ações e situações que se esperariam recalcadas pela sociedade portuguesa da época.

A perversão, como deliberada vontade de fazer o mal pelo mal, pelo desejo sacrílego de violar uma lei e de profanar qualquer coisa de sagrado, transforma-se facilmente em abjeção, isto é, no gozo que alguém extrai não só da voluntária transgressão da norma, mas também da baixeza moral em que, desse modo, se precipita. A abjeção é gosto pela depravação e pela degradação, prazer na má vontade deliberada e no aviltamento que dela resulta, volúpia em humilhar-se e denigrar-se, gozo de poder revolver-se na lama da própria malvadeza e dela obter motivo para mostrar-se com exibicionista auto-complacência, em toda sua baixeza. (PAREYSON, 2012, p.63)

Os artistas que protagonizam as histórias e os eus dos poemas eram seres que ao se inserirem no universo do abjeto, carregavam em si o potencial de execução de todos os interditos maléficos. Eram seres que, por nada temerem, promoviam situações de evasão para uma realidade paralela, uma realidade 
que não cabia a moral cristã e seus pecados. Uma realidade em que os momentos luminosos fossem possíveis, ainda que para que estes existissem fosse necessário que a "parte obscura de nós mesmos" viesse à tona e encontrasse nas ações mais desprezíveis sua realização.

\subsection{1 - O incesto e o sadismo}

O relacionamento entre parentes de primeira linhagem - não sendo levados em consideração apenas os fatores consanguíneos, pois o interdito do incesto também recai sob as relações como as de adoção e tratamento domiciliar equivalente às consanguíneas - é um dos interditos mais condenados por quase todas as culturas.

Claude Leví-Strauss, em seus estudos sobre a origem dos vínculos familiares, registrado em As estruturas fundamentais do parentesco, dedicou-se à busca da origem do repúdio ao incesto e constatou que, embora possa ser evocado o não estímulo da procriação consanguínea, a repulsa ao ato em si ou a necessidade do cumprimento de regras morais estabelecidas, sem que estas necessitem de explicações e justificativas (ROUDINESCO \& PLON, 1998, p.373) concluiu que o repudiado passou a ser apenas para "[...] dar uma solução ao problema da repartição das mulheres disponíveis através da doação." (Apud. BATAILLE, 1987, p.49). Seja pela razão que for, não é possível negar que este é, talvez, um dos interditos mais consagrados pelas mais diversas culturas. Ainda que a lei não necessariamente puna este tipo de relação, se esta for entre adultos e com consentimento se dá, principalmente, nos campos da ética.

Considerado um ato "antissocial" (ROUDINESCO \& PLON, 1998, p.374), cuja punição está muito mais centrada na moralidade, o incesto é marcado pela manifestação de sentimentos torpes, impuros e pecaminosos entre parentes de primeira linhagem, e é exatamente esta a temática do conto "Incesto", o último do livro Princípios. 
No início da enunciação, Luís de Monforte era um homem de quarenta anos que "[...] recordava com uma saudade mal definida as grandes alegrias e as grandes amarguras dos tempos da juventude [...]" (SÁ-CARNEIRO, 1995, p.302). Foi nesta época em que ele era "[...] um espírito alegre, comunicativo e despreocupado, inimigo da solidão." (SÁ-CARNEIRO, 1995, p.304) e que conhecera a atriz Júlia da Gama, uma "[...] criatura perversa e linda [...]" (SÁCARNEIRO, 1995, p.302), com quem ele vivera por quatro anos "[...] num triunfo de amor e felicidade." (SÁ-CARNEIRO, 1995, p.304). A beleza da esposa era como "Duma beleza misteriosa - cabeleira de fogo, olhos de infinito - esboçava-Ihe os lábios sempre úmidos, o sorriso enigmático da Jucunda." (SÁ-CARNEIRO, 1995, p.303). Dona de cabelos ruivos e de um sorriso de Monalisa, a mulher era mais uma vez uma das clássicas mulheres carneirianas, repleta de mistério. $O$ encontro dos dois, segundo o narrador, foi quando "[...] o sonho principiou..." (SÁ-CARNEIRO, 1995, p.303) e, desta união, veio uma filha que "[...] fundia-os agora numa mesma alma a amizade enternecida por aquela criaturinha que era deles, bem deles; que era a personificação viva do seu amor - portanto da sua glória." (SÁ-CARNEIRO, 1995, p.304). A menina teve seu nascimento esperado e comemorado. Ela representava a união do casal, sua ligação. Ela era "a personificação viva do seu amor", um fenômeno raro na obra de Mário de Sá-Carneiro, pois o nascimento e a formação de família são situações que apontam uma consonância com a vida banal tão repudiada no decorrer da obra. Júlia que, em um primeiro momento era "Duma beleza misteriosa", com o advento da maternidade "A existência de Júlia não tinha nada já de misteriosa." (SÁCARNEIRO, 1995, p.304). E, em um dia, o "[...] sonho terminou; começou o pesadelo." (SÁ-CARNEIRO, 1995, p.305), pois em uma carta deixada ao marido ela escreveu apenas: "Filho, Perdoa-me. Mas tem que ser. Fica-te a Leonor. Adeus." (SÁ-CARNEIRO, 1995, p.305). Desta forma, a mulher "[...] desaparecera no turbilhão esfacelante de uma vida arrebatadamente louca, tragicamente agitada [...]" (SÁ-CARNEIRO, 1995, p.302), bem ao gosto da estética decadente, que via na cidade e na rapidez das suas ruas o magnífico e o horrendo. 
Luís criou a filha, Leonor, sozinho. Com muita dedicação, ela se tornara uma jovem maravilhosa, mas que, para o infortúnio do pai, adoecera nas vésperas do casamento, o que a levou a uma morte prematura. O pai, incrédulo com a tragédia de sua vida, sai em viagem e, num momento marcado pela presença da duplicidade, ele conhece uma moça que assim Ihe fora apresentada:

- Minha irmã Magda... O Senhor Luís de Monforte... o pai daquela menina muito parecida contigo, em que te tenho falado tantas vezes...

[...] seis meses mais tarde - com um espanto inconcebível, soube o Dr. Noronha em Lisboa do casamento do seu amigo Luís de Monforte com Magda Ussing. (SÁ-CARNEIRO, 1995, p.336)

O incesto se configura, ainda que a jovem esposa não fosse a própria filha que havia morrido, mas o sentimento que o esposo nutria por ela era um sentimento legitimamente incestuoso: “... E na sua frente, ele via, pois, a cada instante, um rosto lindo que era o da sua filha e - o mesmo sorriso enlevado, o mesmo infinito azul duns grandes olhos tristes. A morta ressuscitara!" (SÁCARNEIRO, 1995, p.336). Com o passar do tempo, foi ficando ainda mais explícita a relação incestuosa que ele mantinha:

Mas afinal era sua filha que ele abraçava todas as noites... mas afinal eram os seios da sua filha que ele beijava... a sua boca que ele mordia!... Era na sua carne, na sua carne esplêndida e sagrada da própria filha, que ele saciava os seus beijos brutais de macho com cio! (SÁ-CARNEIRO, 1995, p.341).

Temos aqui dois interditos concretizados, o do incesto e o do sadismo, pois suas relações com a esposa costumavam ser violentas: "[...] os beijos daquelas bocas [...] foram mordeduras donde o sangue escorrera... Tudo acabara por um arranco supremo de gozo, sibilante e profundo, que mais tinha parecido com o estertor duma agonia horrível..." (SÁ-CARNEIRO, 1995, p.340). O amor entre eles acabava por se manifestar pelo sangue oriundo da boca da moça e um gemido agonizante de alguém entrando em coma, tudo em nome do prazer que 
ele sentia vivenciando tudo isto ao lado dela. A moça simples e virtuosa que viera com ele, apresentava um dos quesitos básicos para a saciedade do sádico, ela era virtuosa e justamente "[...] um requisito do prazer sádico é a existência da virtude [...]." (PRAZ, 1996, p.111).

\subsection{2 - O travestismo}

O travestismo, que vem a ser uma experiência temporária de pertencer ao sexo oposto, aparece em poemas como "Feminina", de Poemas Dispersos, que está escrito em cinco estrofes, com as quatro primeiras compostas por quatro versos e a última por apenas dois, seguidas de uma sequência de reticências.

\footnotetext{
Eu queria ser mulher pra me poder estender

Ao lado dos meus amigos, nas banquettes dos cafés.

Eu queria ser mulher para poder estender

Pó de arroz pelo meu rosto, diante de todos, nos cafés.

Eu queria ser mulher pra não ter que pensar na vida E conhecer muitos velhos a quem pedisse dinheiro Eu queria ser mulher para passar o dia inteiro

A falar de modas e a fazer potins - muito entretida.

Eu queria ser mulher para mexer nos meus seios

E aguçá-los ao espelho, antes de me deitar -

Eu queria ser mulher pra que me fossem bem estes enleios,

Que num homem, francamente, não se podem desculpar.

Eu queria ser mulher para ter muitos amantes

E enganá-los a todos - mesmo ao predileto -

Como eu gostava de enganar o meu amante loiro, o mais esbelto, Com um rapaz gordo e feio, de modos extravagantes...

Eu queria ser mulher para excitar quem me olhasse, Eu queria ser mulher para me poder recusar...
}

Paris, fevereiro de 1916 (SÁ-CARNEIRO, 1995, p. 148)

No poema, o eu lírico nos coloca uma sequência machista e estereotipada do que ele acredita que venha a ser o universo feminino. Nesta perspectiva, ele elenca as razões pelas quais acredita que travestir-se para esta nova realidade devesse ser bastante prazerosa. Ele deseja "ser mulher pra não ter que pensar 
na vida", "para passar o dia inteiro/A falar de modas", por exemplo. Esta vida sem absolutamente nenhuma responsabilidade, cheia de ocupações fúteis, demonstra um certo desconhecimento da realidade feminina cotidiana ou mais uma fantasia só possível numa realidade paralela, numa realidade artificial.

A partir da terceira estrofe, o poema se cobre de sensualidade, pois, contrariamente à visão masculina que ele carrega em sua primeira parte, em que apenas apresenta o dia a dia feminino sem grandes atribuições, mostrando uma mulher frágil e sem perspectiva, a partir da terceira estrofe esse jogo acaba se modificando, quando o eu começa a manifestar sua predileção pelos seios femininos "Eu queria ser mulher para mexer nos meus seios/E aguçá-los ao espelho, antes de me deitar -", por sua vontade de desprezar os amantes "Como eu gostava de enganar o meu amante" e pela vontade de despertar desejos nos homens "para excitar quem me olhasse", ele passa a mostrar a mulher serpente. O seu desejo de ser uma mulher poderosa como Salomé, que pode e deseja excitar e recusar. Assim, travestido de mulher, o eu poderia concretizar alguns de seus desejos, fazendo diminuir as frustrações de não poder possuir.

\subsection{3 - A homossexualidade}

No período que engloba a produção artística de Mário de Sá-Carneiro, a homossexualidade era vista pela perspectiva da doença, da perversão, o "[...] sujeito não era, [...] senão um objeto perdido na tormenta de uma classificação que o reduzia à insignificância ao confiscá-lo de sua parte sombria." (ROUDINESCO, 2008, p.103).

$\mathrm{Na}$ época cristã - e como em todas as religiões monoteístas -, o homossexual tornou-se a figura paradigmática do perverso. O que assim o qualificava era a escolha de um ato sexual em detrimento de outro. Ser sodomita queria dizer recusar a diferença dita "natural" dos sexos, a qual supunha que o coito fosse consumado com fins procriadores. Daí resultava que todo ato sexual que infringisse essa regra era visto como perverso [...]. (ROUDINESCO, 2008, p.50) 
O sexo, na obra carneiriana, é o que Roudinesco apontaria como uma sexualidade perversa, não apenas por sua condição não religiosa mas, principalmente, pela negação da formação da família e de uma "possível" vontade de Deus na criação de apenas dois sexos.

A questão da negação divina se coloca com grande força na obra, não apenas por estar inserida em uma realidade cristã, como a portuguesa, mas também por explicitar em suas páginas não conhecer "[...] alguma coisa mais desoladora do que isto de só haver dois sexos?" (SÁ-CARNEIRO, 1995, p.477), proporcionando, assim, a criação de uma espécie de terceiro sexo, um sexo marcado pela androgenia, pela figura da esfinge.

Receptáculo de um amor visto como impuro e não aceito, a imagem da homossexualidade está em toda obra carneiriana. Não exclusivamente na forma do travestismo do sujeito literário, como vimos anteriormente, mas pela aceitação desta possibilidade de relacionamento, ainda que talvez tenha faltado ao autor uma certa coragem em abordar o assunto um pouco mais de frente, fazendo com que ele apenas permitisse que as personagens secundárias da obra vivessem explicitamente sua homossexualidade.

A Americana, de A confissão de Lúcio, era vista como "[...] uma criatura interessantíssima. É muito artista... Aquelas duas pequenas são amantes dela. É uma grande sáfica." (SÁ-CARNEIRO, 1995, p.359). A mulher sáfica que é vista na obra é artista, estrangeira e, talvez, justamente pela distância de sua terra natal, é que tenha sido possível a realização da sua sexualidade de maneira tão aberta. Já às personagens principais, aos narradores de muitos textos, o amor sexualizado se resume a um grande atropelo de sentimentos e de dúvidas. A impossibilidade de vivenciar estes amores se resume à certeza de que:

[...] não posso ser amigo de ninguém... [...] um desejo de beijar... de estreitar... Enfim: de possuir! [...] Para as sentir, isto é, para ser amigo de alguém (visto que em mim a ternura equivale à amizade) forçoso me seria antes possuir quem eu estimasse, ou mulher ou homem [...]. (SÁ-CARNEIRO, 1995, p.376) 
Repleta de personagens masculinos infelizes afetivamente, a sensação do "não amor" é constante, como no poema "Quase", de Dispersão, um símbolo deste amor não realizado.

Quase o amor, quase o triunfo e a chama, Quase o princípio e o fim - quase a expansão... Mas na minh'alma tudo se derrama...

Entanto nada foi só ilusão!

Num ímpeto difuso de quebranto,

Tudo encetei e nada possuí...

Hoje, de mim, só resta o desencanto

Das coisas que beijei mas não vivi...

Um pouco mais de sol - e fora brasa,

Um pouco mais de azul - e fora além.

Para atingir, faltou-me um golpe de aza...

Se ao menos eu permanecesse aquém..

(SÁ-CARNEIRO, 1995, p.65)

A "vaguidão" de ser "quase" amado e se notar como expressão de um amor que não se realiza, que não se concretiza, também é manifestado no poema "Como eu não possuo", de Dispersão, em que os versos explicitam a impossibilidade de ser amigo de alguém pela sua incapacidade de possuir um outro, fosse homem ou mulher.

Olho em volta de mim. Todos possuem -

Um afeto, um sorriso ou um abraço.

Só para mim as ânsias se diluem

E não possuo mesmo quando enlaço.

[...]

Não sou amigo de ninguém. Pra o ser

Forçoso me era antes possuir

Quem eu estimasse - ou homem ou mulher,

E eu não logro nunca possuir!...

(SÁ-CARNEIRO, 1995, p.65) 
A verdade é que aí temos deflagrada a impossibilidade de viver qualquer amor no plano da realidade, e a homossexualidade só se manifesta se vivida num plano de realidade paralela ao factual. O sexo, meramente físico, é comum de ser repugnado:

A Náusea maior - pelo menos o vômito negro sucedendo ao espasmo dourado. Coisas peganhentas e úmidas, malcheirosas, repugnantes... Onde encontrar beleza nos contatos do cio? Beleza... Mas haverá ridículo mais torpe?... Ah!, o horror dos sexos - cartilagens imundas, crespas, hilariantes... E os suspiros da cópula; as contrações picarescas suadas... Infâmia sem nome! Infâmia sem nome! Como resistir a tudo isto uma alma sensível?... (SÁ-CARNEIRO, 1995, p. 546)

O sexo "peganhento", registrado em "Ressurreição", de Céu em Fogo, é algo intolerável a "uma alma sensível" e esta alma deseja uma união "[...] astralmente, de corpos longínquos, purificados, incertos e livres!..." (SÁCARNEIRO, 1995, p. 546). Sendo assim, o amor homossexual se dá muito mais no campo da idealidade, como registrado pelo campo semântico de palavras como "astralmente", "espaço ideal, ondulante e translúcido" (SÁCARNEIRO, 1995, p.546) se referindo ao ato sexual.

Como o amor homossexual sem culpa não é natural no contexto da obra, uma possível saída para a vivência da experiência de união entre o desejo homossexual e o sexo "astral" seja manifestado pela possível projeção/criação da figura de Marta, de A confissão de Lúcio. Ela se tornara amante de Lúcio, mas ele não tinha absoluta certeza da existência dela, pois sua presença estava sempre muito envolvida numa atmosfera de mistério. Sobre a vida da amante, ele comentou: "[...] nem era só de seu passado que eu ignorava tudo - também duvidava de seu presente. [...] Sim, em verdade, era como se não vivesse quando estava longe de mim." (SÁ-CARNEIRO, 1995, p.391), sendo ela alguém projetado/criado, era através de sua figura que o encontro entre Lúcio e Ricardo se dá e, desta forma, os beijos deles acabavam sendo sentidos da mesma maneira: "O beijo de Ricardo fora igual, exatamente igual, tivera a mesma cor, a mesma perturbação que os beijos da minha amante. Eu sentira-o da mesma maneira." (SÁ-CARNEIRO, 1995, p.394). O desejo dele por ela 
perpassava pela ideia de possuir alguém de seu sexo "[...] — ao possuí-la, eu tinha a sensação monstruosa de possuir também o corpo masculino desse amante." (SÁ-CARNEIRO, 1995, p.399), ficando explicitada se não a homossexualidade concretizada no plano real, ao menos o seu desejo "astral" de vivê-la.

\subsection{4 - O voyeurismo}

O voyeurismo é considerado uma "[...] desordem sexual que consiste na observação de uma pessoa no ato de se despir, nua ou realizando atos sexuais" (HOUAISS, 2004, p.2883) sendo necessário que o objeto observado não se saiba observado. Este é um comportamento encontrado nas páginas de A confissão de Lúcio, por exemplo. Embora não apareça na sua forma mais usual, mas na observação da vida íntima de outrem, pois, na obra, o triângulo amoroso vivido por Lúcio/Marta/Ricardo, em um determinado momento, passa a ser tema de reflexão para Lúcio, pois ele percebe que Ricardo não apenas sabia dos casos da esposa com vários homens, como era ele próprio quem escolhia os parceiros dela. Esta escolha do marido pelos amantes da esposa retira de Marta a condição de adúltera, ela deixa de ser culpada por algo, para apenas ser aquela que proporcionava o prazer do próprio marido em saber dos detalhes de seus relacionamentos com outros homens. "- Sim! Marta foi tua amante, e não foi só tua amante... Mas eu não soube nunca quem eram os seus amantes. Ela que mo dizia sempre... Eu é que Ihos mostrava sempre?" (SÁ-CARNEIRO, 1995, p.410). O que faz com que acreditemos que todas as vezes que Lúcio entrou na casa do amigo após o início do seu relacionamento com Marta, muito possivelmente o amigo já soubesse dos fatos e, se não os observava efetivamente, pois não há marcas textuais que possam provar isso, ao menos fica provado que ele sentia prazer em saber dos casos extraconjugais da mulher.

\subsection{5 - Outros interditos}

Lúcio, de A confissão de Lúcio, conta parte de suas experiências em suas linhas confessionais e algumas delas são exemplos de outros interditos 
apontados por Roudinesco (2008) como perversos. Experiência de natureza sádica pode ser vista quando, ao se encontrar com sua amante, Lúcio, em "um dia de triunfo, finalmente, descobre-Ihe no seio esquerdo uma grande nódoa negra... Num ímpeto, numa fúria, colei a minha boca a essa mancha chupando-a trincando-a, dilacerando-a..." (SÁ-CARNEIRO, 1995, p.398). O prazer de Lúcio não se deu apenas pela experiência erótica de tocar os seios femininos como o comum a muitos, mas pela descoberta de uma "nódoa negra", que não é um indício saudável; aqui a doença é mais uma vez motivo de atração e, ao poder "colar" seus lábios, que dá a noção da força, da avidez com que se deu ao ato, ele dilacera a mancha "chupando-a trincando-a".

Ao lembrar-se de como possuiu Marta, Lúcio faz a seguinte declaração: "Sim, ao esvaí-la, ao lembrar-me de a ter esvaído, subia-me sempre um além-gosto a doença, a monstruosidade, como se possuíra uma criança, um ser de outra espécie ou um cadáver..." (SÁ-CARNEIRO, 1995, p.390). As lembranças do momento são difíceis de serem precisadas, e o narrador faz uso de expressões abstratas como "além-gosto", que nos faz supor que sejam gostos superiores, que estão além dos gostos triviais, convencionais, um gosto maior, extra, que ele associa à "doença", à "monstruosidade" e, como se isso ainda dissesse pouco, ele lança mão de três grandes interditos que acompanham nossa sociedade: a pedofilia "possuíra uma criança", a zoofilia "um ser de outra espécie" e a necrofilia "um cadáver". A imagem erotizada de crianças e de animais se repete em "Ressurreição", onde temos: "[...] um cheiro a madeiras velhas, poças de lama, doçuras gordurosas, bafos avinhados - 0 peito hirsuto dum carregador, sexos de crianças, membros de animais..." (SÁ-CARNEIRO, 1995, p.549), descritas com tom naturalista, estas expressões se associam a sensações sinestésicas, como o cheiro rústico da madeira e a lama; as doçuras (infantis) gordurosas e bafos ébrios de vinho, que formulam uma imagem de certa degeneração, um rebaixamento, que só não faz com que a poética carneiriana tenda para a grosseria pela elegância impregnada na linguagem. Talvez este seja um dos grandes pontos de sabedoria do autor, que, para tornar viável a escrita de tantas temáticas espinhosas, optou por uma roupagem mais sofisticada, fazendo com que fosse possível a circulação de seus textos na virada do século. 


\section{3 - 0 vício}

Contrariamente ao que poderia ser esperado num universo de valorização da boemia, de relações sexuais liberais e do culto ao mistério, o uso de entorpecentes é um expediente não muito habitual na obra de Mário de SáCarneiro. Ele faz pouco, ou quase nenhum uso deste recurso para a construção de suas personagens. Talvez seja pela busca incessante da novidade e de uma vida desregrada, que ele negue o vício comum, pois manter-se entorpecido é um hábito, implica em rotina. Em "O incesto" o narrador comenta a este respeito nas palavras de Luís de Monforte: "Eis uma das poucas coisas de que eu me posso orgulhar na minha vida: nunca fiz nada que não gostasse de fazer e que pudesse deixar de fazer. Por isso não fumo e raras vezes me tenho embebedado." (SÁ-CARNEIRO, 1995, p.307).

O toxicômano, por exemplo, precisa rotineiramente do entorpecente para poder se manter, e a ideia de manter uma rotina física é abominável no contexto da obra, pois, para esta, o vício, o que entorpece não é produzido por substâncias narcóticas, mas pela volúpia da arte. Em a Orgia do Fogo, de A confissão de Lúcio, a sensação registrada pelo narrador era a de que a "[...] impressão fora tão forte, a maravilha tão alucinadora, que não tivemos ânimo para dizer uma só palavra." (SÁ-CARNEIRO, 1995, p.364). Um dos adjetivos escolhidos para descrever o momento vivido foi "alucinadora", ou seja, aquilo que provoca a alucinação, como se a orgia realmente tivesse o papel do entorpecente. Ele, "[...] ao acordar de um sonho de onze horas" (SÁ-CARNEIRO, 1995, p.364) parecia incrédulo com o que havia acontecido, o término do efeito fazia com que a realidade novamente the fosse percebida. A arte e os artistas são o entorpecente e o entorpecido da obra carneiriana e, a respeito deles, Lúcio manifesta:

Ah! como Gervásio tinha razão, como eu no fundo abominava essa gente - os artistas. Isto é, os falsos artistas cuja obra se encerra nas suas atitudes; que falam petulantemente, que se mostram complicados de sentidos e apetites, artificiais, irritantes, intoleráveis. Enfim, que são os exploradores da arte apenas no que ela tem de falso e de exterior. 
Mas, na minha incoerência de espírito, logo me vinha outra ideia: "Ora, se os odiava, era ao final por invejar e não poder nem saber como eles..."

Em todo caso, mesmo abominando-os realmente, o certo é que me atraíam como um vício pernicioso. (SÁ-CARNEIRO, 1995, p.358)

Tomado pela incoerência, o narrador formula ideias de amor e ódio aos mesmos seres, oscilando entre a admiração e a repulsa ele, seja qual for o prato que mais pese, acaba tendo na figura do artista e da arte uma de suas grandes temáticas nos alertando: "- Acho que não devem discutir o papel da voluptuosidade na arte porque, meus amigos, a voluptuosidade é uma arte e, talvez, a mais bela de todas." (SÁ-CARNEIRO, 1995, p.356).

Em busca desta famigerada beleza oriunda da arte, é que Mário de SáCarneiro orna sua obra com as mais exóticas mulheres ruivas, de pele mordorada, altamente sensuais e misteriosas, como as de Egon Schiele, servindo como objetos para experiências perversas e contundentes. Elas, ao lado de homens e eu líricos adoradores das artes, fazem com que esta tenha seu papel insubstituível em todo contexto da obra do referido autor e é sobre o papel da arte na poética carneiriana que falaremos nas considerações do capítulo final. 


\section{CAPÍTULO 4 - A ARTE COMO SOPRO DE VIDA}

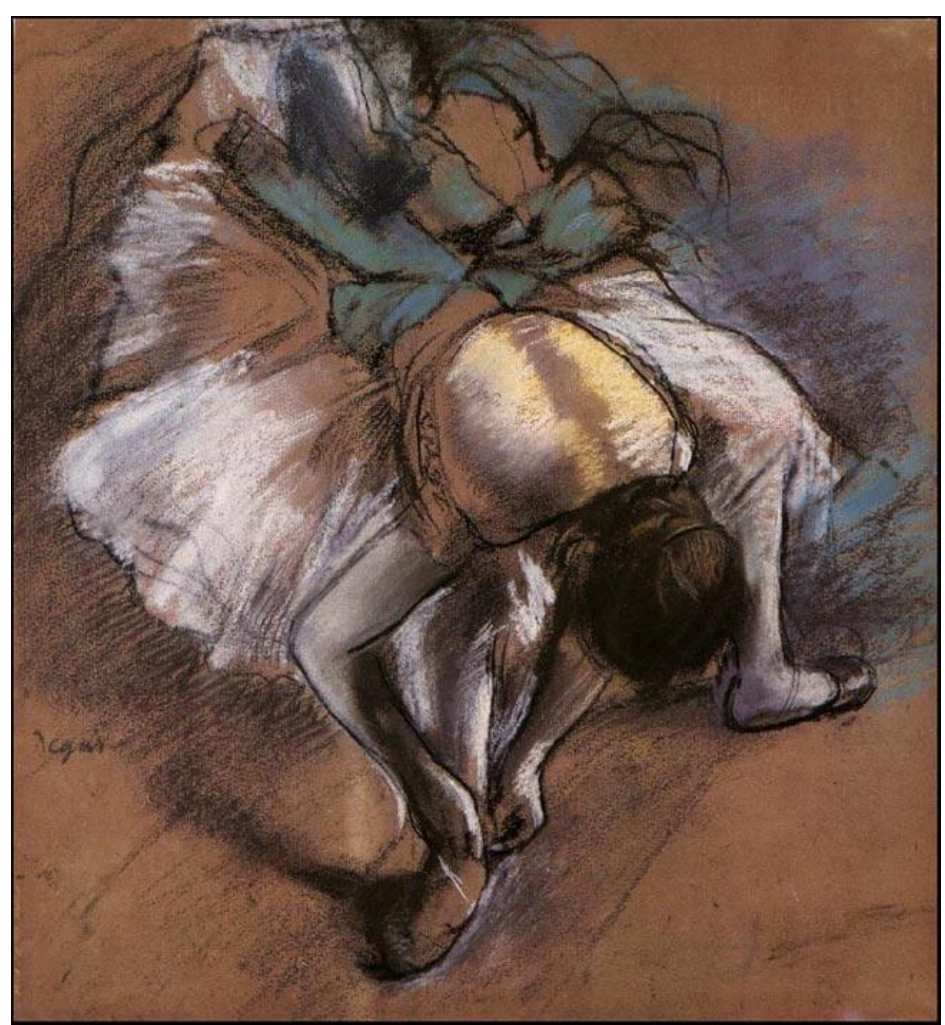

DEGAS, Edgard. Bailarina ajustando sua sapatilha.

"A abra de arte passui também a seu caráter sagrada!... Uma única abra de arte 'viva' leastará para a imartalidade da artista... - Os meus quadras devem ser expastas em edificias semelhantes a templas."

Egan Schiele, Schiele. 
No conto "O Fixador de Instantes", de Céu em fogo, há a expressão "O INSTANTE! O instante" (SÁ-CARNEIRO, 1995, p. 430), no início do texto. Estas palavras dão o tom da narrativa e mostram a força e a dificuldade de concretização do projeto, que será anunciado posteriormente pelo narrador. Como bem diz o nome do conto, a pretensão é a de ser capaz de fixar o instante, ou seja, conseguir a congruência entre a eternidade e o efêmero, entre o fugaz e o atemporal, entre a realidade e a idealidade. A busca recorrente da apreensão do instante, que tão bem é posta no título, é marcada pelo verbo "fixar", que dá uma ideia de rigidez, realidade, concretude e, para além de sua carga semântica, o verbo ainda tem por característica ser um verbo transitivo direto, pedindo, portanto, um objeto. Quebrando a expectativa do leitor, o objeto direto apresentado não está cunhado nos parâmetros do palpável - como seria o esperado - muito pelo contrário, é cingido pelo abstracionismo, pela fugacidade, pela falta de concretude, só ampliando a dificuldade já explicitada pelo narrador de conquistar o objetivo por ele imposto. Ao que parece, a imensa dificuldade de execução do projeto por ele traçado é devidamente pensada e sugerida para que a ardilosidade, o engenho, a sagacidade do narrador sejam postos à prova e, naturalmente, ao ter o êxito em sua execução, deixa clara a grandeza do feito, enaltecendo o vitorioso.

Como mostrado, o projeto de vida do narrador é o de ser capaz de congelar, de preservar o instante e, assim, ser o dominador do tempo e dos campos da eternidade. Conquistada esta capacidade, o narrador manifesta a sua indignação perante aqueles pobres seres que ainda desconhecem 0 seu segredo, de fazer ir e voltar o tempo por meio da fixação dos instantes: "Não sei como os outros que desconhecem o meu segredo, a minha arte, podem viver da vida. Não sei." (SÁ-CARNEIRO, 1995, p. 530). Nesta passagem, o narrador-personagem coloca seu leitor diante de alguns dos seus juízos de valor mais caros: ele pensa, julga e sentencia sua incredulidade à vida cotidiana. Desta forma, vai categorizando as pessoas em dois grupos bastante distintos: os que conhecem e os que desconhecem o segredo dele, mostrando sua indignação perante isso. Esta mesma indignação não aparece apenas em "O fixador de instantes", mas em vários outros contos como, por exemplo, em "O homem dos sonhos", que registra a alegria da personagem em evitar ter 
uma vida comum: "- A vida é um lugar-comum. Eu soube evitar esse lugarcomum. Eis tudo." (SÁ-CARNEIRO, 1995, p.480); ou ainda em "Mistério", em que temos: "E na manhã seguinte, após um sono seguido de dez horas, acordou morto de sono para viver mais um dia igual e vazio da sua vida..." (SÁCARNEIRO, 1995, p.465).

A incredulidade mediante aqueles que ainda não tiveram o privilégio de conhecer o segredo do "fixador", aqueles que estão "mortos de sono", vivendo vidas iguais e vazias, se acentua pelo fato dele não apenas indignar-se com isso, é muito mais. Ele não acredita, nem ao menos, em como estas pessoas podem conseguir "viver da vida". Fato interessante é a colocação da contração "da" e não do usual "a" vida. A vida como nos é posta, com o "da", aponta uma relação de dependência, servidão e ele não aceita isso, ele não se coloca no patamar daqueles que vivem da vida, mas no patamar daqueles que são capazes de manipular, cuidar, fixar instantes desta vida e isso, segundo ele, é para poucos, apenas para aqueles que conhecem o segredo, os considerados escolhidos.

A maneira como isso é posto ao leitor provoca a sensação de que os homens comuns são seres passivos no caminhar de suas histórias, são os homens resignados, que aceitam os desígnios da vida sem contestação, sem percepção, e aponta ser a subserviência o que os torna capazes de aceitar a cotidianidade. Eles são os sobreviventes de um processo reificante, do qual não têm nem ao menos a consciência de estarem inseridos. "O homem felicíssimo, em verdade, é um pobre recebedor de contas pelas mãos do qual, diariamente, milhões se precipitam e que, no entanto, vê os seus filhos morrerem à fome." (SÁ-CARNEIRO, 1995, p.530). Este alienado "homem felicíssimo" a que se refere o narrador não tem espaço nas páginas carneirianas, eles não são dignos de habitar as páginas sagradas da literatura. A obra do autor prega uma veemente aversão ao homem que forma família, que é cristão, que teme o pecado, aquele que, segundo Nietzsche, constitui o grupo formado pelos "[...] falhados, os insatisfeitos, os tombados pelos males quotidianos, toda a escória social." (NIETZSCHE,1985, p.82). 
A pergunta que se forma para o leitor é, então, a de "como seria possível ser o conhecedor do "segredo", ser capaz de fixar o instante?" e, desta forma, escapar da terrível sina de ser um homem comum, inserido num processo de servidão e rotina. E a resposta dada por Mário de Sá-Carneiro para esta e tantas outras questões formuladas na extensão de sua obra é apenas uma: por meio da arte.

Segundo Hauser (2000), a época do romantismo era dada especialmente por obras literárias que apresentavam suas personagens demasiadamente voltadas ao cumprimento dos padrões e condições socialmente aceitáveis. Regido pela religião, o homem buscava estar e se adequar completamente aos padrões sociais que, historicamente, Ihe foi imposto: aos homens cabia a tarefa de serem provedores e, às mulheres, a de gerenciar suas famílias.

A religião, como aqui está posta, não é aquela exclusivamente manifestada em culto, não é a vinculada a uma instituição em si, pois "Para a maioria do povo [...] a religião deve ser primariamente uma questão de comportamento e hábito, deve integrar-se na sua vida social, no seu trabalho e nos seus prazeres." (ELIOT, 1992, p.92) e, sendo assim, qualquer pessoa, considerando-se crente ou não, é partícipe dos comportamentos da sociedade em que está inserida e acaba, direta ou indiretamente, sendo influenciada pela religião local; isso se dá, segundo o autor, pela natural falta de reflexão a respeito da doutrina, o que faz com que ele diferencie dois cristianismos — o do hábito e o da instituição embora seja o segundo que autorize o primeiro.

O Estado é um incentivador da manutenção da religião, pois esta acarreta na aceitação passiva da crença e do poder, sendo um mecanismo de educação bastante promissor.

Numa sociedade cristã, a educação deve ser religiosa, não no sentido de que será administrada por eclesiásticos, ainda menos no sentido de que exercerá pressão ou de que tentará ensinar teologia a toda gente, mas no sentido de que seus objetivos se orientarão por uma filosofia cristã de vida. (ELIOT, 1992, p.96) 
Portanto, a moral cristã está impregnada na cultura portuguesa, independentemente do cidadão ser (ou não) um indivíduo frequentador de uma igreja, seja ele um "cristão de hábito" ou de "instituição", pois a moral cristã se dá pela passagem dos costumes e dos comportamentos que geram os hábitos, e isto atinge até mesmo aqueles que se consideram ateus.

No final do século XIX, era de bom tom que todos mantivessem aparência de felicidade e o ideal era que não fosse possível constatarem-se máculas nas famílias burguesas. "O romântico estava demasiado ligado à vida, quer dizer, a um anseio de vida; era mero sentimento, mera natureza." (HAUSER, 2000, p.807). Ao afirmar que o romântico era alguém que nutria apenas sentimento, que era composto apenas de natureza, Hauser aponta exatamente um homem que se opõe ao artista, pois, para este homem, o valorizado era a artificialidade e não o natural ${ }^{8}$.

A "natureza" é para gente-sadia, a subgente normal... Nós, excessivos em Oiro, libertamo-nos dela. Engano-me contrariamente, aumentâmo-la: demos-lhe alma, e só o seu espírito - o espírito que lhe criamos - nos suscita os desejos. Somos gente de Alma - projetamos a alma a quanto admiramos, a quanto apetecemos... (SÁ-CARNEIRO, 1995, p.569)

Cabia à natureza, aqui também vista como religião, nesta época, a tarefa de nortear os comportamentos e confortar o homem nos momentos de agrura, mas, aos decadentes do final do século, estas perspectivas, este consolo, não faziam mais o menor sentido. Cético, o narrador aponta que a natureza era para "gente-sadia", mas imediatamente acaba por depreciar esta gente ao tratá-la por "subgente", distinguindo estes "normais" dos "excessivos em Oiro", sem medo de um julgamento divino, sem a presença de um Deus, sem se sentir um pecador e, menos ainda, em busca de seu Salvador.

\footnotetext{
${ }^{8}$ Cabe dizer que a ideia de natureza só é aceita se esta representar a possibilidade de fruição dos instintos mais primitivos no homem, aqueles instintos que foram reprimidos pela presença da educação e que, aos decadentes, aparecem na forma da realização dos desejos mais íntimos e proibidos.
} 
Mesmo um homem que tem a mais modesta pretensão à integridade deve saber que um teólogo, um padre, um papa de hoje, não somente erra, quando fala, mas na realidade mente - e desse modo não mais escapa à censura de mentir por "inocência" ou "ignorância". O padre sabe, como todo o mundo sabe, que não há qualquer "Deus", qualquer "pecador" ou qualquer "Salvador", que "livre arbítrio" e "ordem moral do mundo" não passam de mentiras: reflexão séria, a profunda autoconquista do espírito, não permite a qualquer homem fingir que não saiba disso... (NIETZSCHE,1985, p.73-74)

Certamente, a ideia de que "qualquer homem" seria capaz de perceber "que não há qualquer "Deus'" seja uma possibilidade equivocada, mas a filosofia pessimista de Nietzsche gozava de amplo prestígio na época de Mário de SáCarneiro. Os eus e narradores são receptáculos de um tédio, de um descontentamento que se mostra em consonância com ela. Abandonado pela ideia de ter um Deus, o homem passa a estar sozinho e precisa ser capaz de superar todas as suas dificuldades sem nenhum consolo divino. Dada a impotência da situação, o descontentamento e a infelicidade se tornam eternos e qualquer pequeno desejo que se mostre alcançado é a abertura para o tédio da conquista e a busca de um novo desejo. A resignação e o servilismo característicos da alienação são substituídos pelo espírito de inconformidade, pela busca de uma ação, que chega pela arte nas páginas de Sá-Carneiro. Nietzsche (1985) decreta que Deus morreu, abrindo os caminhos para o aparecimento de um homem superior, principalmente mediante os mais fracos, um homem capaz de ser seu próprio Deus, capaz de controlar o tempo, de criar mundos e, este homem é para Sá-Carneiro, o artista.

Segundo Gomes:

O Artista, à luz do decadentismo, será o torturado, o rebelde, o incompreendido, o demiurgo baudelairiano, o místico aristocrata de Mallarmé, o super-homem de Rimbaud, o aureolado de SáCarneiro, o dandy wildiano. Com essa conjugação de epítetos, tudo o que parta do artista será rotulado de superior [...]. (GOMES, 2006, p.130) 
Dono de uma superioridade singular e na esteira de grandes nomes associados a uma literatura maldita, Sá-Carneiro apresenta em sua obra a crença na figura do artista como um ser superior, um ser dotado da capacidade de se esquivar da vida real, construindo uma realidade paralela. $O$ artista passa, desta forma, a transformar e a ser transformado pela realidade. Ele consome o mundo real e o transforma da maneira que considera adequada na produção artística. E este efeito da transformação, que é o objeto artístico em si, apresenta o que Bataille (1998) aponta como a retirada do utilitarismo das coisas. O objeto artístico se sustenta por sua própria existência, sem a necessidade de nenhuma funcionalidade, retirando qualquer possibilidade de associação da obra carneiriana a algum tipo de engajamento social ou político. Segundo Galhóz: "A obra de arte vai da magia ao utilitarismo, do esteticismo puro à função determinada, do servilismo venal à gratuidade, da afirmação, em si mesma suficiente, às instâncias mais fundas da nossa disponibilidade." (1963, p.29).

Num processo de negação da perspectiva passiva e conservadora da vida, e encabeçados por Charles Baudelaire, a arte decadentista passa a apresentar um novo olhar para a vida, um olhar em que há uma ruptura com a atitude passiva perante ela e, desta maneira, a atitude meramente contemplativa dá lugar a um "sensualismo hedonista" (HAUSER, 2009, p.909). O sensualismo hedonista a que Hauser faz menção vai ao encontro da ideia decadente de negação da religião. $O$ artista reconhece e encontra o sagrado pela arte, sua epifania vem pela produção artística que, nesta medida, o eleva à condição de Criador. Sua criação primordial, que é a obra, é o receptáculo de seu domínio e presteza em transformar a realidade. Roudinesco afirma que "[...] os libertinos, insubmissos e rebeldes, buscavam viver como deuses e, portanto, libertar-se da lei religiosa, tanto pela blasfêmia quanto por práticas voluptuosas da sexualidade." (2008, p.44).

Ao passo que este artista se percebe o Criador, se sente Deus e, por meio de suas mãos um novo mundo pode ser criado, o tempo e o espaço podem ser por ele manipulados, os instantes perdidos podem ser fixados. $O$ ser descontínuo a que Bataille (1998) se refere, encontra, enfim, uma forma de 
continuidade, mas sem a necessidade da reprodução. O sexo para a perpetuação da espécie é colocado de lado e este agora está, exclusivamente, ligado ao prazer. Cabe à obra de arte, e não aos filhos, perpetuar o artista.

Os artistas decadentes da época perdem o pouco que talvez lhes restasse de sua conexão com a vida real e, dessa forma, passam quase que, exclusivamente, a viver experiências em suas últimas consequências e, assim, a arte toma uma dimensão jamais vista. Ela passa a substituir antigas instituições e o artista passa, então, a se empenhar em "converter sua vida numa obra de arte". (HAUSER, 2000, p.910).

A obra de arte não é só considerada um fim em si mesma, não só um jogo auto-suficiente, cujo fascínio é suscetível de ser destruído por um propósito extrínseco, extra-estético, não só a mais bela dádiva que a vida tem a oferecer, para a fruição da qual é dever de cada um preparar-se devotadamente, mas tornase, ademais, em sua autonomia, sua falta de consideração por tudo o que está fora de sua esfera, um padrão para a própria vida do diletante, que começa agora a desalojar os heróis intelectuais do passado, no apreço de poetas e escritores, e representa o ideal do fin de siècle. (HAUSER, 2000, p.909-910)

Hauser afirma que a arte torna-se um padrão para a vida do diletante, e não apenas o artista do final do século reivindica o direito de dar a ela um caráter de elevação, mas também a si mesmo. O autor faz menção ao artista como um ser capaz de substituir os heróis de outros tempos, como o próprio Mário de Sá-Carneiro coloca em "Páginas de um suicida", quinto conto de Princípio, em que o encontro com a morte é visto como um encontro com um local, um espaço a ser descoberto e a personagem se compara, neste momento, aos grandes navegadores.

Serei como um arrojado descobridor de mundos: Colombo descobriu a América; Vasco da Gama, a Índia... eu descobrirei a Morte!... Uma diferença haverá apenas: eu guardarei a minha "descoberta" só para mim; eles fizeram presente das suas à humanidade... Foram generosos. Serei egoísta... (SÁ-CARNEIRO, 1995, p. 262) 
Situado entre os heróis de outros tempos, embora Hauser cite a figura deste em pessoa - e não apenas de sua obra -, a utilização de dados biográficos não é uma perspectiva usada neste estudo, esta análise apenas recai nas personagens das narrativas carneirianas, que são invariavelmente artistas, juntamente com seus eu-líricos de poemas, pois todos parecem executar, dentro do plano literário, o objetivo descrito por Hauser de fazer uma "[...] renúncia à vida por amor à arte [...]." (HAUSER, 2000, p.910). É possível ver que, na obra, o mundo da arte é "[...] a única compensação verdadeira para os desapontamentos da vida, a genuína realização e consumação de uma existência intrinsecamente incompleta e inarticulada." (HAUSER, 2000, p.910).

A arte se mostra como a grande redentora do mundo. Ela possibilita, redime, transcende. Retira do humano sua condição de apenas animal e o eleva à condição de detentor e produtor de cultura. É, nesta esfera, que a capacidade de executar um projeto artístico confere ao homem o "status" divino de controlar o tempo e fazê-lo ir e voltar todas as vezes que achar conveniente. Não mais se deseja apenas viver da vida, mas agora o desejo é de ser capaz de gerar momentos gloriosos, ou ainda, mais do que isso, ser capaz de ir e voltar estes momentos no tempo. Poder "[...] - ter tido e ter!" (SÁ-CARNEIRO, 1995, p. 531), como nos aponta outra vez o narrador de "O fixador de instantes".

O mesmo narrador diz ter sido "[...] uma reminiscência longínqua - donde, ignoro - de muito longe, de além-sonho talvez, que me ensinou o segredo." (SÁ-CARNEIRO, 1995, p. 530). Ele confessa que estava diante do segredo que iria revitalizar sua vida e o segredo a que ele se refere é o de ter a capacidade de produzir "arte".

Usando da metáfora de que a vida nada mais é do que um livro, e que ele, narrador, é o seu escritor/leitor, pois pode utilizar, a todo instante, sua capacidade de ir e voltar às páginas sem nenhum tipo de impedimento. Nessa dimensão, a vida e a arte passam a ser uma coisa só e a insistência no desejo de fixação torna-se mais que possível, torna-se a própria matéria da vida. 
Sei vê-lo, ressenti-lo, como quem folheia um livro já lido, mas que pode tornar a ler.

Graças ao meu segredo eu folheio a existência - mas folheio realmente; não evoco apenas, morto de saudade vaga, as suas páginas rasgadas. Que para os mais, os dias da vida são páginas rasgadas logo depois de lidas. (SÁ-CARNEIRO, 1995, p. 531)

Embora imbuído de uma postura demiúrgica, o narrador se atém a dizer que se distancia da imagem do Deus postulado pela cultura judaico/cristã em que está inserido, porque não é capaz de ser criador daquilo que é mundano. Ele é o fixador, o que embalsama o instante para ser revisto a qualquer momento: "Não ressuscito. Petrifico." (SÁ-CARNEIRO, 1995, p.531). Num lapso de humildade, sua colocação - de que não é um Criador em nada - diminui sua sensação demiúrgica, afinal, apesar de não assumir essa condição, designa-se como aquele capaz de manipular o tempo. O que, para um homem crente, nada mais é do que possuir poder divino.

Posto, teoricamente, seu projeto de vida/arte e a maneira como foi capaz de chegar a ele, a personagem relembra um de seus momentos mais gloriosos: quando foi capaz de fixar um ano inteiro de sua estada na "grande capital", referência à cidade de Paris, que personifica tudo que é mais "[...] ultracivilizado!" (SÁ-CARNEIRO, 1995, p. 531). Ciente da impossibilidade de sorver daquele espaço pelo resto de sua vida, o narrador percebe o desafio que the é posto, e passa ao trabalho de fixá-lo.

Assim a comecei fixando, emoção após emoção - pouco a pouco, pois ela era enorme - como quem pregasse com alfinetes, lentamente, cuidadosamente, uma grande peça de linho.

Petrifiquei-a, sim, no meu coração, a capital das ânsias; enchi-a para o meu sentir de pontos de referência, de rastros áureos através maravilhas! Tenho-a!... Tenho-a!... (SÁ-CARNEIRO, 1995, p. 532)

Caminhando por bairros da capital em busca de experiências, o encontro inicial do narrador com sua amada se deu numa pensão em que "[...] viviam algumas raparigas do norte, daquelas raças louras do norte que eu tanto sinto, e entre 
elas, uma de quem tinha mais saudade, loura também e eslava - dessa Rússia onde, estranhamente, vive qualquer coisa de mim." (SÁ-CARNEIRO, 1995, p.532). O mistério e o exotismo, mais uma vez, aparecem na obra carneiriana representados pelas mulheres russas, dotadas de madeixas louras/ruivas. Num universo tomado pelo labor artístico, a conversa entre os dois flui com tranquilidade e o ponto alto se dá quando os versos dele são lidos na voz dela, pois ali o narrador percebe que havia um ponto a ser fixado: "Ela falara só para mim, e nunca mais, nunca mais, repetiria as palavras que murmurara só para mim." (SÁ-CARNEIRO, 1995, p.532).

$\mathrm{Na}$ sequência do texto, surge um desencontro da vida do narrador, com a partida súbita da jovem russa que fez com que ele selasse a existência dela com a imagem do corte de um caule de uma rosa, que a moça tocou em seu último instante na cidade, antes de partir.

Meti a rosa esquecida num jarro de água... Na tarde seguinte, como o meu amigo não a viesse reclamar, ungidamente eu cortei o caule da flor - que os seus dedos eslavos decerto haviam apertado - e algumas pétalas fanadas. Encerrei estes pobres vestígios num grande sobrescrito, que lacrei, escrevendo por fora 0 seu nome sonoro, fluidamente ruivo. (SÁ-CARNEIRO, 1995, p. 532)

$\mathrm{O}$ ato, aparentemente banal, mostra as etapas metodológicas do processo de composição da vida (livro), de como a figura fixada não passa de uma personagem que serve para alimentar a mente do narrador. Ela, como humana, de nada vale a ele. Ela vale pelo que representa dentro de um contexto muito específico. Neste caso, o de ser parte do enredo da página em que houve a leitura do poema do narrador, em uma noite qualquer. Ela é mais uma página de lembranças que pode, a todo momento, ser relida ou, até mesmo, algo "[...] que eu posso destruir [...] se quiser, rasgarei o sobrescrito - abaterei um instante da minha cidade. A maior prova de que o vivi, de que o tinha: só quem possui pode despedaçar." (SÁ-CARNEIRO, 1995, p. 533). Suas companhias não passam de personagens em um enredo maior do narrador, que é a própria vida. Suas ambições, vontades, idiossincrasias em nada sensibilizam ou 
interessam a ele. Ele simplesmente as usa para a composição de sua maior obra e, nesta dimensão, matar, por exemplo, seria irrelevante. Entramos em um mundo absolutamente particular, onde as regras externas, as moralidades socialmente compostas perdem seu valor. Agora, as regras passam a ser apenas as colocadas pelo jogo instaurado do próprio narrador. Lugares, pessoas, ações tornam-se exclusivamente meios para se alcançar a plenitude da obra, pois, na condição de Criador, ele tudo pode.

Numa metáfora paralela à principal, o narrador compara sua composição com a tela dos pintores, que usam da técnica do esfumaçamento. Suas imagens perdem $o$ ar de realidade factual para ganhar o de realidade verossímil. Em processo semelhante, ele deixa de andar pelos espaços que tão bem conhecia, aqueles de que poderia se lembrar sem dificuldade alguma, a qualquer momento, para caminhar pelos bairros mais distantes do centro. Sua não compreensão destes lugares faz com que o processo de esfumaçamento se desse e, desta forma, ele ganha a eternidade, pois deixa de ser exclusivamente iconográfico, para ser sinestésico. "Logo, amanhã, eu posso recordá-lo sentindo-o. Não vendo-o apenas. Eis como emprestei ao total a bruma que uma obra destas precisa para ser eterna." (SÁ-CARNEIRO, 1995, p. 533).

O processo de enlaçamento dos instantes se completa pela sequência de ações, assim descritas pelo narrador: "Desfolho rosas, esparzo aromas, tilinto oiro sobre as horas belas que existo, e assim as enlaço!..." (SÁ-CARNEIRO, 1995, p. 533). É a plenitude. O enlaçamento por via da arte faz com que a vida se concretize e justifique todas as ações.

O projeto artístico carneiriano se apresenta mais uma vez no quarto texto de Céu em fogo, "Asas". Nele, temos a narração de um grande desafio a ser conquistado pela personagem Petrus Ivanowitch. O poeta, descrito na narrativa, deseja escrever um livro cujo título ainda não sabe no ato da enunciação, "[...] será, quando muito, um compasso de música e alguns traços a cor." (SÁ-CARNEIRO, 1995, p.489). A personagem mostra um desejo de escrever um poema repleto de abstracionismo, com características atribuídas à música, ao desenho, à pintura. $\mathrm{O}$ autor ainda desejava que o poema: "Dividir- 
se-ia [...] em várias partes, em várias composições. Mas todas elas, soltas, haviam de reunir astralmente, hipnoticamente (foi os termos que empregou) em um só conjunto." (SÁ-CARNEIRO, 1995, p.490). Em terceira pessoa, o narrador, que era amigo da personagem, se mostra surpreendido com o uso das palavras "hipnoticamente" e "astralmente" usadas pelo artista. A obra por ele almejada era uma composição que rompia com a tradição e com os processos conhecidos para a gênese de um poema. A obra, de caráter fantástico, era a concretização de uma vida que, no plano da realidade, não era possível de ser realizada, revelando "[...] uma vontade de ruptura com o mundo para melhor abraçar a vida na sua plenitude e descobrir, na criação artística, o que a realidade recusa." (BATAILLE, 1998, p.15-16). A arte, neste texto, se mostra como campo fecundo para a realização de um projeto de vida, impraticável no contexto puramente social.

A identidade tão buscada e questionada em toda obra de Mário de Sá-Carneiro parece que, enfim, encontra um ponto de encontro, de equilíbrio. A angústia de se saber, identificar e perceber tem seu fim pela própria obra, pelo reconhecimento do traço estilístico. "Sabemos que um traço linguístico só é reconhecido como traço de estilo quando seu valor expressivo é notado [...]" (ZAMBONIM, 2000, p.28). A mesma obra que recebe as inquietações é aquela que identifica e dá autenticidade ao seu autor. Contrariamente às palavras de Gervásio em A confissão de Lúcio, que equivocadamente aponta "[...] que o artista não se revela por suas obras, mas sim, unicamente, por sua personalidade." (SÁ-CARNEIRO, 1995, p.357), é na obra que encontramos a poética, é por ela que se concretiza a identidade. Para Mourão é a linguagem que confere identidade. A linguagem é "[...] o instrumento de uma identidade [...] a linguagem não "traduz" a realidade [...]" (1992, p. 131), mas sim "[...] cria uma nova realidade." (1992, p. 131). É na linguagem que se identifica o artista, é na sua obra que o artista se faz perceber.

São expressões como "Desfolho rosas, esparzo aromas, tilinto oiro" (SÁCARNEIRO, 1995, p.533) que são capazes de promover a identificação das composições de Mário de Sá-Carneiro. "No artista que cria, acontece a força volitiva do desejo, o impulso fecundante e, mais tarde, a claridade em que 
reconhece sua obra, lhe dá o seu nome." (GALHÓZ, 1963, p.28). Em “O incesto", fica registrado:

O prazer de criar avantaja-se a todos. Em frente da arte, o artista esquece. A sua dor, se não se cura, suaviza-se pelo menos. A arte é um refúgio. [...] a criança refugia-se junto dos seus brinquedos, e abraça-os e beija-os. O artista, na sua angústia, consola-se com a sua arte. É que a arte é também no fundo um "brinquedo". Os homens são crianças eternas. (SÁ-CARNEIRO, 1995, p.307)

Assim como a obra é o refúgio do artista, é nela que ele se cura, onde encontra a alegria do brinquedo infantil, com o qual se identifica e é identificado. Cabe à literatura carneiriana ser o ponto de identificação do artista, assim como as bailarinas de Edgar Degas também o são. O esfumaçamento presente na bailarina, seu cuidado com as sapatilhas, a "mundanidade" deflagrada em seu corpo fora da dança são a representação daquilo que vem por trás da beleza, da graciosidade do gesto. Ela é a representação do artista que sangra, que se exaure, que sente dor, mas que se entrega à arte e por ela é capaz de qualquer renúncia. Ela representa a dor, o labor, o sacrifício; mas, mais que isso, tal qual Sá-Carneiro aponta em momentos de sua obra, ela representa o ritual. A arte tem sua ritualística, tem sua liturgia, que precisa ser atendida para se atingir a epifania. Nessa liturgia, temos Degas calçando as sapatilhas de sua bailarina para o esplendor da dança, ainda que lhe custe toda a dor que lhe cabe; temos Baudelaire (1998) gritando na voz do narrador de o "Mau vidraceiro", para que este jamais ande pelas ruas pobres de Paris sem os vidros das mais belas cores, pois a vida precisa ser bela de se ver; temos ainda Mário de Sá-Carneiro registrando as mais íntimas confissões de suas personagens e eus, sem censura ou medo, marchetadas num vocabulário de "oiro" e que se tornam uma representação legítima daquilo a que chamamos de "literatura do mal". 


\section{CONSIDERAÇÕES FINAIS}

Como vimos no decorrer desta tese, a obra de Mário de Sá-Carneiro, do final do século XIX ao início do XX, está inserida historicamente num período de grandes transformações sociais em que o homem se percebe parte de uma sociedade célere, cuja valorização estava muito centrada no acúmulo de bens e na produção em massa, fazendo com que a percepção da individualidade se deslocasse das escolhas pessoais, dos gostos próprios, da família de origem, entre outras possibilidades, para a representação do que o indivíduo é nesta nova sociedade. A manifestação de suas idiossincrasias perde espaço para a valorização das semelhanças entre os seres.

Segundo Heidegger (2011) este tipo de sociedade provoca o deslocamento das questões ônticas do ser para o ente e este deslocamento, culmina na alienação da maioria dos homens a respeito de sua condição como ser. Ainda que pese o fato de ser o homem o único dos seres capaz de refletir sobre sua própria existência, o deslocamento da reflexão de quem se é a partir do ser para o mundo (de dentro para fora) faz com que grande parte dos homens não mais encontre as respostas necessárias em si e parta em busca do reconhecimento de sua identidade num eixo oposto ao que seria natural. O homem passa a fazer das coisas, do mundo exterior, a medida para se constata quem se é. $O$ indivíduo passa a ser identificado e valorizado pelas igualdades de hábitos e 
costumes que o assemelham a seus pares na sociedade. A busca frenética para acompanhar esta rotina de assemelhar-se ao outro é uma das responsáveis pelo aumento significativo de tarefas diárias, inviabilizando uma possível reflexão a cerca de si mesmo.

Muito atarefado em suas obrigações cotidianas, apenas alguns poucos homens são capazes de refletir e de ter consciência de sua condição no mundo. Estes poucos seres dotados de consciência são aqueles que sofrem da angústia de não desejarem ter as mesmas vidas que seus contemporâneos. Eles se negam a simplesmente reproduzir os mesmos padrões e comportamentos que deles são esperados. A negação desta vida banal, que a falta de consciência impõe, é que faz das personagens e eus da obra de Mário de Sá-Carneiro seres atormentados por sua própria condição de consciência e pela busca de uma vida autêntica que os faça sentir apaziguados perante a inadequação que sentem ao se colocarem no mundo.

Cansados da rotina a que estão inseridos, as personagens e eus buscam a criação de uma realidade paralela para darem vazão às suas individualidades. Esta nova realidade possibilita que o indivíduo se desprenda das convenções morais comuns da sociedade em que está inserido e passe a dar vazão, sem censura, aos seus mais íntimos pensamentos e vontades, ainda que estes, algumas vezes, venham agregados à ruína, ao infortúnio, à doença, ao nocivo. Ou seja, que sejam vontades e pensamentos que quando transformados em ações possam culminar no mal.

O preço da autenticidade buscada é o de precisar se ausentar da vida chamada de real para inscrever-se numa nova realidade, uma realidade criada. Não ser capaz de aceitar e conviver com as convenções sociais, com a religião, com as tarefas diárias, o trabalho, entre outros, justifica a necessidade da evasão, mas apenas evadir-se não basta, para se ter uma vida autêntica, que realmente seja significativa é preciso evadir e criar esse novo mundo e, uma vez criado, dar a ele a singularidade, a grandeza que o faça distinto dos demais. O tom que referenda esta nova realidade é o do mistério, pois estando nele envolvido, tudo se torna possível pela perda da necessidade de uma 
coerência com o mundo factual. A verossimilhança é que assegura tudo ser possível e as personagens e eus fazem uso do mistério em busca de momentos tão singulares, que sejam capazes de despertar as mais vibrantes sensações, as mais inusitadas ações, que, desta forma, concedam às personagens e eus os "momentos luminosos" que justificam a vida.

A fuga para uma nova realidade, a busca por uma atmosfera de mistério e sombras encoraja e está à serviço da realização dos sentimentos e ações mais íntimos e obscuros. Neste universo paralelo, são cometidos atos que no mundo real não seriam permitidos. São crimes, adultérios, interditos, sem que estes sejam vistos como terríveis. Mais do que aceitos, muitos deles mostram-se justificados, mostram-se autorizados por este novo conceito de realidade. A obra de Mário de Sá-Carneiro nos convida a ver bem de perto a obscuridade da alma humana, sem que esteja provida de um juízo de valor que a condene. $\mathrm{Na}$ realidade paralela a que ela está posta, esta literatura do mal se mostra referendada, principalmente por ser executada pelo mais elevado tipo humano que a obra carneiriana reverencia: 0 artista.

O artista, nesta perspectiva, é o único tipo que interessa ao autor, pois à medida que este deseja produzir um universo dotado do que ele considera que exista de mais requintado no mundo, a única categoria que se mostra à altura de habitar esta realidade é o artista. Dono da capacidade criadora, o artista se aproxima da imagem do Deus cristão. É ele quem cria, quem julga, quem condena, que chega ao sublime por sua própria capacidade de criação e, por sua condição "divina" tudo lhe é autorizado. Seus atos não são questionados, tampouco passivos de serem julgados e/ou punidos.

O sagrado não está mais reservado aos templos religiosos, ele está vinculado aos teatros, cafés, salas das casas burguesas que recebiam aos saraus. Ele está envolto ao comportamento profano que por meio do tratamento estético passa a ser considerado sublime.

"Beleza, perversidade, vício e doença." (SÁ-CARNEIRO, 1995, p.357) são palavras registradas nas páginas iniciais de $\mathbf{A}$ confissão de Lúcio e, a partir 
delas é possível se extrair a essência de uma poética voltada àquilo a que denominamos de "literatura do mal". Promovendo a associação do belo, por meio da valorização da arte, da liberdade de ações e pensamentos, que na obra, culminam com um conjunto de ações perversas; incentivando o vício pelas noites boemias, pela autoflagelação, pela dor e levando suas personagens e eus numa proximidade quase que letal à doença, a obra de Mário de Sá-Carneiro é uma representante legítima da "literatura do mal". 


\section{BIBLIOGRAFIA DO AUTOR}

SÁ-CARNEIRO. Mário de. A estranha morte do professor Antena. Posfácio e fixação do texto de Maria João Simões. Rio de Janeiro: 7 Letras, 2008.

- Céu em Fogo. Introdução, organização e notas de António Quadros. Lisboa: Publicações Europa-América, s/d.

Obra Completa. Introdução e organização de Alexei Bueno. Rio de Janeiro: Nova Aguilar S.A., 1995.

\section{BIBLIOGRAFIA SOBRE O AUTOR}

ARAÚJO, Fiorella Ornellas de. Do duplo à abjeção: uma leitura de A confissão de Lúcio de Mário de Sá-Carneiro. 2009. Dissertação (Mestrado em Letras) USP. São Paulo.

BELLODI, Zina Maria. Função e forma do tradicional em Mário de Sá-Carneiro. Caderno de Teoria e Critica Literária - 5. Faculdade de Filosofia e Letras de Araraquara, 1975.

BERRINI, Beatriz. Livros de Portugal - ontem e hoje. São Paulo: Cortez, 1981. 
CABRAL, Filomena. Um teatro de papel (Uma leitura da encenação da luxúria em A confissão de Lúcio de Mário de Sá-Carneiro). In: ENCONTRO DE CENTROS DE ESTUDOS PORTUGUESES NO BRASIL, 2, 1997. Rio de Janeiro. Anais do II Encontro de Centros de Estudos Portugueses no Brasil. Rio de Janeiro: UFRJ, p.15-20, 1997.

CARPINTEIRO, Maria da Graça. A novela poética de Mário de Sá-Carneiro. Lisboa: Publicações do centro de estudos filológicos, 1960.

FILHO, Leodegário de Azevedo. Mário de Sá-Carneiro e a teoria do duplo. In: SEMANA DE ESTUDOS SÁ-CARNEIRO. 1994. Belo Horizonte. Anais, atas etc. da Semana de Estudos Sá-Carneiro. Belo Horizonte: UFMG, p.2-9, 1994.

GALHOZ, Maria Aliete. Mário de Sá-Carneiro. Lisboa: Editorial Presença, 1963.

Mário de Sá-Carneiro. In: SIMÕES, João Gaspar. Crítica V Críticos e ensaístas contemporâneos (1942 - 1979). Lisboa: Imprensa Nacional - Casa da Moeda, 1983.

GARCEZ, Maria Helena Nery. A imagem do labirinto na poesia de Camões e Sá-Carneiro. O Estado de São Paulo, São Paulo, Suplemento Cultural, Jul 1978.

. Fernando Pessoa leitor de Mário de Sá-Carneiro. In: CONGRESSO INTERNACIONAL DE ESTUDOS PESSOANOS, IV, 1990. s.I. Actas do IV Congresso Internacional de estudos pessoanos - Secção brasileira. s.l.: Fundação Eng. António de Almeida, p.5-10, 1990.

O "estrambótico" em Mário de Sá-Carneiro. Revista Língua e Literatura, São Paulo, № 15, p.15-20, Jul. 1986.

. Trilhas em Fernando Pessoa e Mário de Sá-Carneiro. São Paulo: Moraes/ Editora da Universidade de São Paulo, 1989.

Uma desventura mítica. Uberlândia: Letras \& Letras. Ano IV, №. 41, Fev. 1991. 
GOMES, Fátima Inácio. O imaginário sexual na obra de Mário de Sá-Carneiro. Lisboa: Imprensa Nacional - Casa da Moeda, 2006.

MACHADO, Lino. Inter-relações: A confissão de Lúcio e outros textos de Mário de Sá-Carneiro. In: SEMANA DE ESTUDOS SÁ-CARNEIRO. 1994. Belo Horizonte. Anais, atas etc. da Semana de Estudos Sá-Carneiro. Belo Horizonte: UFMG, p.2-9, 1994.

. Transgressão e castigo em Mário de Sá-Carneiro. ENCONTRO DE PROFESSORES UNIVERSITÁRIOS BRASILEIROS DE LITERATURA PORTUGUESA, 12,1992. Rio de Janeiro. Anais do XIII Encontro de professores universitários brasileiros de literatura Portuguesa. Rio de Janeiro: UFRJ, p. 2532, 1992.

MARTINS, Fernando Cabral. O modernismo em Mário de Sá-Carneiro. Lisboa: Imprensa universitária - Editorial Estampa, 1994.

MIRANDA, José Américo. A confissão de Lúcio: encenação de um suicídio. In: SEMANA DE ESTUDOS SÁ-CARNEIRO. 1994. Belo Horizonte. Anais, atas etc. da Semana de Estudos Sá-Carneiro. Belo Horizonte: UFMG, p.11-15, 1994.

NEVES, João Alves das. As novelas do 'Princípio' e outros textos excluídos das Obras completas de Mário de Sá-Carneiro. In: SEMANA DE ESTUDOS SÁCARNEIRO. 1994. Belo Horizonte. Anais, atas etc. da Semana de Estudos SáCarneiro. Belo Horizonte: UFMG, p.2-9, 1994.

PAIXÃO, Fernando. Narciso em sacrifício - a poética de Mário de Sá-Carneiro. Cotia: Ateliê Editorial, 2003.

PIEDADE, Ana Nascimento. A questão estética em Mário de Sá-Carneiro. Lisboa: Universidade Aberta, 1994.

RÉGIO, José. Ensaios de interpretação crítica. 2 ed. Porto: Brasília Editora, 1980. 
SILVA, Jaqueline Fernandes da. A imagem do suicídio nos versos de Mário de Sá-Carneiro. 2011. Dissertação (Mestrado em Letras) - USP. São Paulo.

WOLL, Dieter. Realidade e idealidade na lírica de Mário de Sá-Carneiro. Tradução Maria Manuela Gouveia Delille. Lisboa: Delfos, 1968.

ZOFIAN, Marita Astolfi. A representação metafórica em Mário de Sá-Carneiro, 1995. Tese (Doutorado em Letras) - USP. São Paulo.

\section{BIBLIOGRAFIA GERAL}

ALMEIDA, Onésimo Teotônio. Mensagem - uma tentativa de reinterpretação. Angra do Heroísmo: Secretaria Regional de Educação e Cultura. Diretoria Regional dos Assuntos Culturais, 1987.

ALVAREZ, Aurora Gedra Ruiz. "A sátira menipeia e o mito relendo a modernidade". Todas as Letras, São Paulo, v. 12, n.2, p.20-31, 2010.

AUGÉ, Marc. Não-Lugares: Introdução a uma antropologia da supermodernidade. São Paulo: Papirus, 2010.

BACHELARD, Gaston. A poética do devaneio. São Paulo: WMF Martins Fontes, 2009.

BATAILLE, Georges. A literatura e o mal. Lisboa: Vega - Passagens, 1998.

O erotismo. Tradução de Antonio Carlos Viana. Porto Alegre: L\&PM, 1987.

BAUDELAIRE, Charles. As flores do mal. Rio de Janeiro: Nova Fronteira, 1985. Pequenos poemas em prosa. Rio de Janeiro: Record, 2006. Sobre a Modernidade. São Paulo: Paz e Terra, 1997. 
BAUDRILLARD, Jean. Simulacros e Simulação. Lisboa: Relógio d'água, 1991.

BENJAMIN, Walter. Charles Baudelaire um lírico no auge do capitalismo. São Paulo: Brasiliense, 1989.

BÍBLIA. Português. Bíblia Sagrada. Tradução de Matos Soares. São Paulo: Paulinas, 1976.

BRUNEL, Pierre. Dicionário de mitos literários. Rio de Janeiro: José Olímpio, 2005.

BULFINCH, Thomas. O livro de ouro da mitologia. Rio de Janeiro: Ediouro, 2000.

CABANNE, Pierre. Toulouse-Lautrec, Le peintre de La vie moderne. Paris: Terrail, 2003.

DEBORD, Guy. A sociedade do espetáculo. Rio de Janeiro: Contraponto, 1997.

DOSTOIÉVSKI, Fiódor. Notas do subsolo. Tradução de Maria Aparecida Botelho Pereira Soares. Porto Alegre: L\&PM, 2012.

O Idiota. Tradução de Paulo Bezerra. São Paulo: Editora 34, 2002.

DUBOIS, Christian. Heidegger: Introdução a uma leitura. Rio de Janeiro: Jorge Zahar Editor, 2004.

ECO, Humberto. História da Beleza. Rio de Janeiro: Record, 2004.

ELIOT, T. S.. Ensaios escolhidos. Sel. Trad. Notas Maria Adelaide Ramos. Lisboa: Cotovia, 1992.

GROWE, Bernd. Degas. (S.I.): Taschen, 2001. 
GUIMARÃES, Fernando. Poética do simbolismo em Portugal. São Paulo: Imprensa Nacional - Casa da Moeda, 1990.

HAUSER, Arnold. História social da arte e da literatura. 3 ed. São Paulo: Martins Fontes, 2000.

HEIDEGGER, Martin. O que é metafísica? Trad. Ernildo Stein. São Paulo: Livraria Duas Cidades. 1969.

. Ser e tempo. Rio de Janeiro: Vozes; Bragança Paulista: Editora Universitária São Francisco, 2011.

HENRIQUES, Rogério Paes. "De H. Cleckley ao DSM-IV-TR: a evolução do conceito de psiocopatia rumo à medicação da delinquência". Revista Latinoam. Psicopat. Fund., São Paulo, v. 12, n. 2, p.285-302, Jun 2009.

HOUAISS, Antônio; VILLAR, Mauro de Salles; FRANCO, Francisco Manoel de Mello. Dicionário Houaiss da Língua Portuguesa. Rio de Janeiro: Objetiva, 2004.

HUYSMANS, Joris Karl. Às avessas. São Paulo: Cia das Letras, 1987.

JUNG, Carl Gustav. O eu e o inconsciente. Petrópolis: Vozes, 1977.

KUJAWSKI, Gilberto de Mello. A crise do século XX. São Paulo: Ática, 1991. "Panorama da Belle Époque". O Estado de S. Paulo. Caderno de Cultura, Ano VII, no 420, p. 2, Ago 1988.

LACAN, Jacques. "Kant com Sade". In: Escritos. Rio de Janeiro: Jorge Zahar, 1998.

LOPES, Oscar; SARAIVA, Antonio José. História da literatura portuguesa. 16 ed. Porto: Porto Editora, 1995. 
LOURENÇO, Eduardo. A nau de Ícaro e miragem da lusofonia. São Paulo: Companhia das Letras, 2001.

MOISÉS, Massaud. A literatura portuguesa. 26 ed. São Paulo: Cultrix, 1994.

MORETTO, Fulvia M. L. Organização, tradução e notas. Caminhos do decadentismo francês. São Paulo: Perspectiva, 1989.

MOURÃO, José Augusto Mourão. "A literatura e o Mal: Torga, Celan e Duras". Revista Colóquio de Letras. 125/126, p.129-138, 1992.

NAVES, Gilzane Silva. Liberdade e autenticidade em Martin Heidegger: uma análise fenomenológica do homem. Uberlândia: Poros, 2009.

NIETZSCHE, Friedrich. O Anticristo. Trad. David Jardim Júnior. Rio de Janeiro: Ediouro, 1985.

Assim falou Zaratustra. São Paulo: Martin Claret, 2011.

PAREYSON, Luigi. Dostoiévski: filosofia, romance e experiência religiosa. Tradução Maria Helena Nery Garcez e Sylvia Mendes Carneiro. São Paulo: Edusp, 2012.

PESSOA, Fernando. Antologia poética. São Paulo: Moderna, 1997.

PEYLET, Gerard. La littérature fin de siècle - de 1884 à 1898 - Entre décadentisme et modernité. Paris: Vuibert, 1994.

PIERI, Paolo Francesco. Dicionário Junguiano. Petrópolis: Vozes, 2002.

PLATÃO. A República. $6^{\circ}$ ed. São Paulo: Atena, 1956.

Diálogos. Col. Os pensadores. São Paulo: Abril Cultural, 1983.

O Banquete. Porto Alegre: L\&PM, 2009. 
PRAZ, Mário. A carne, a morte e o diabo na literatura romântica. São Paulo: Editora da Unicamp, 1996.

PUENTE, Fernando Rey. (org.) Os filósofos e o suicídio. Belo Horizonte: Editora da UFMG, 2008.

RIBEIRO, Raquel de Sousa. "A caverna de José Saramago: a imagem e a prolação". Todas as Letras, São Paulo, n.8, p.11-25, 2006.

. "O navegador e a busca". Todas as Letras, São Paulo, n.2, p.39-

48, 2000.

ROSSET, Clement. O real e seu duplo: ensaio sobre a ilusão. Tradução de José Thomaz de Brum. 2ªed. Rio de Janeiro: José Olympio, 2008.

ROUDINESCO, Elisabeth. A parte obscura de nós mesmos - Uma história dos perversos. Rio de Janeiro: Zahar, 2008.

ROUDINESCO, Elisabeth. PLON, Michel. Dicionário de psicanálise. Rio de Janeiro: Zahar, 1998.

SADE, Marquês. Os infortúnios da virtude. São Paulo: lluminuras, 2009.

SERRA, José António. "Mistério", E-Dicionário de Termos Literários, Coordenação de Carlos Ceia. Disponível em: www.edtl.com.pt.

SCHOPENHAUER, Arthur. O mundo como vontade e como representação.

Trad. Jair Barboza. São Paulo: Ed. Unesp, 2005.

STEINER, Reinhard. Schiele. (S.I.): Taschen, 2001.

SWINGLEHURST, Edmund. A arte dos surrealistas. Rio de Janeiro: Ediouro, 1997. 
VECHI, Carlos Alberto. "Sebastianismo: o fracassado mito de origem". Todas as Letras, São Paulo, n.5, p.85-94, 2003.

VILLAR, Mauro. Dicionário contrastivo luso-brasileiro. Rio de Janeiro: Guanabara, 1989.

WERLE, Marco Aurélio. A angústia, o nada e a morte em Heidegger. São Paulo: Transformação, 2003.

ZAMBONIM, Maria Thereza Martinho. "Signos de movimento". Todas as Letras (São Paulo), n.2, p.27-37, 2000. 


\section{ANEXOS}

\section{FIGURA 01}

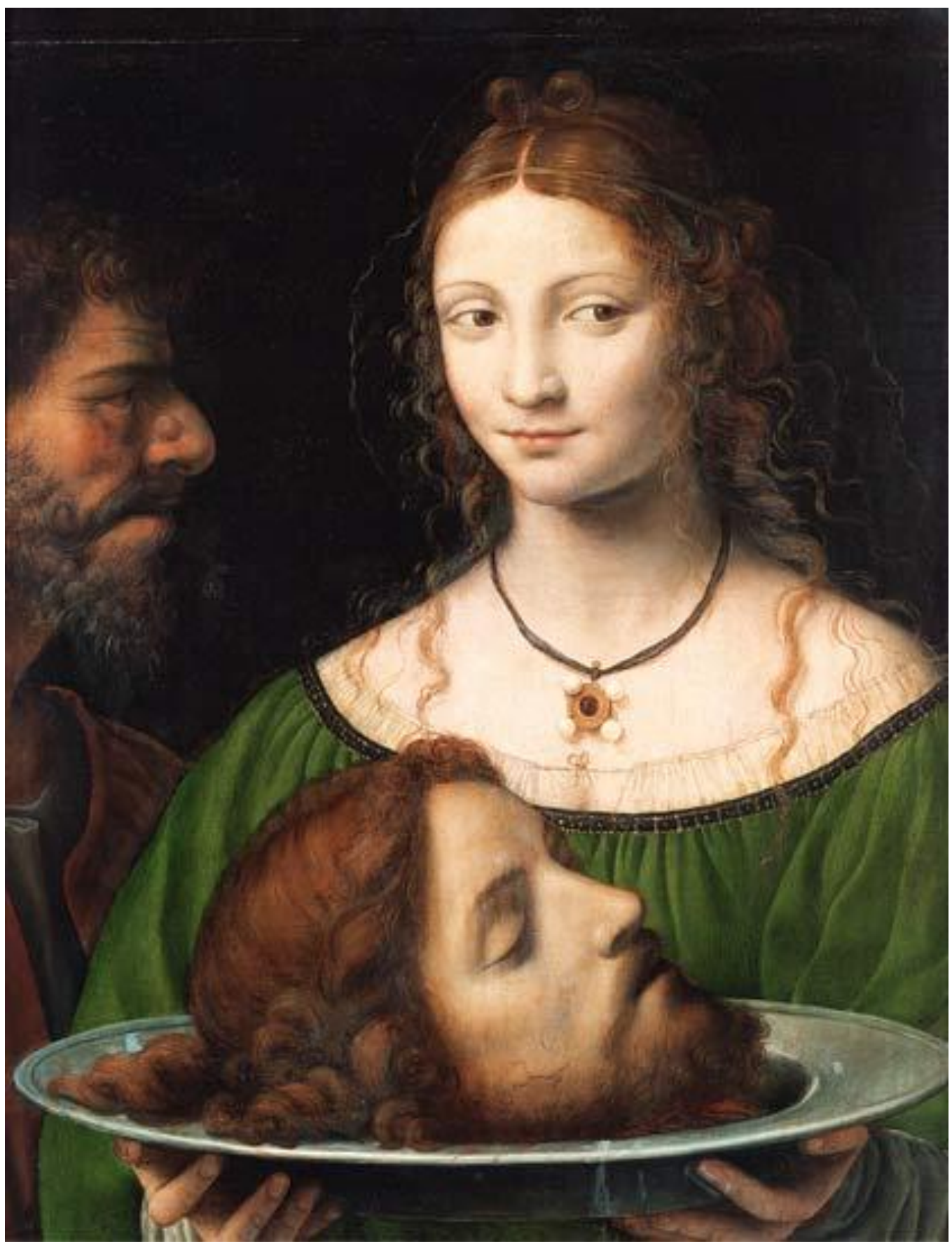

Salomé com a cabeça de João Batista

Autor: Bernardino Luini $(1480$ - 1532)

Data da Obra: Provavelmente entre 1525-30 
FIGURA 02

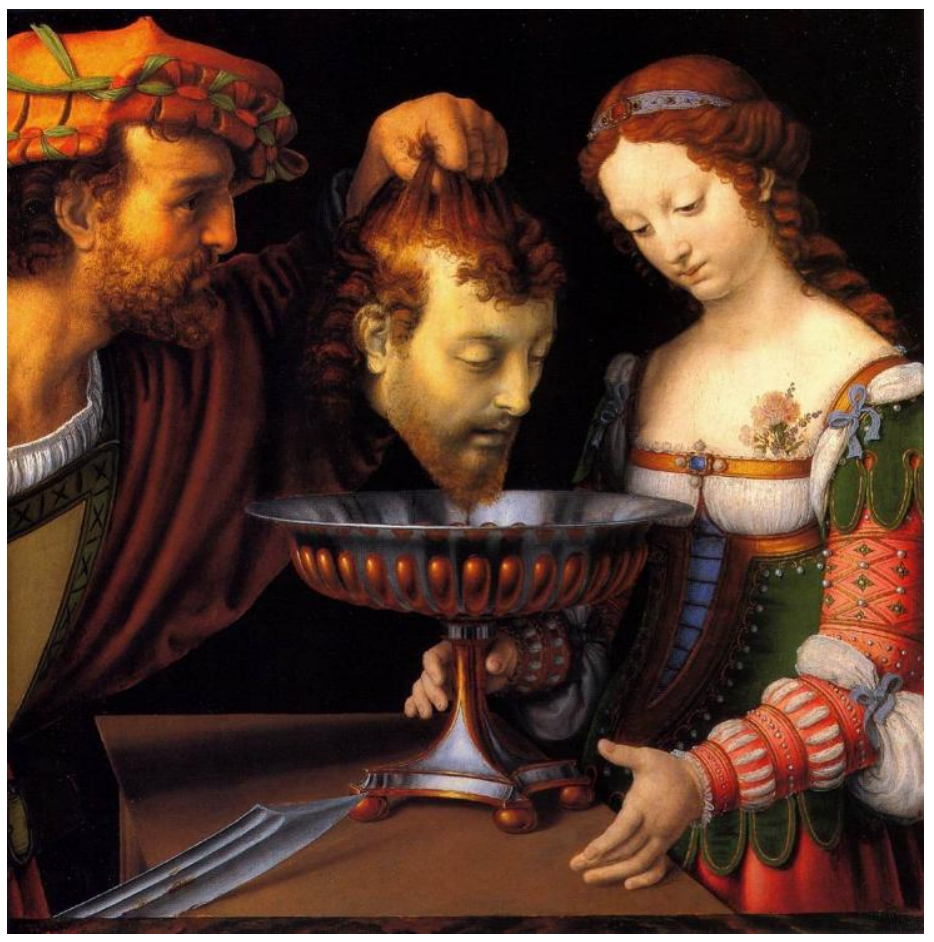

Salomé

Autor: Andrea Solari (1460 - 1524)

Ano da obra: Provavelmente entre 1520-24

FIGURA 03

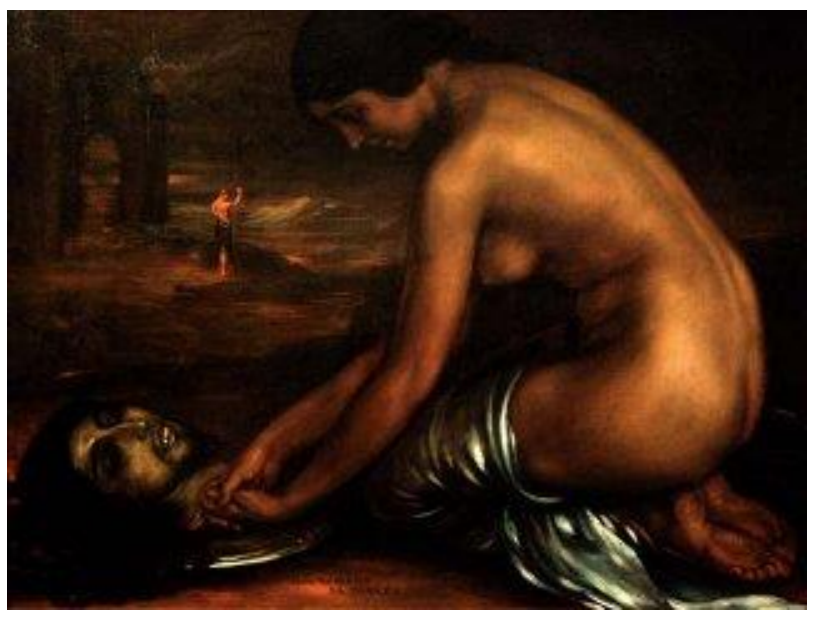

Salomé

Autor: Júlio Romero de Torres (1874 - 1930)

Ano da obra: 1913 
FIGURA 04

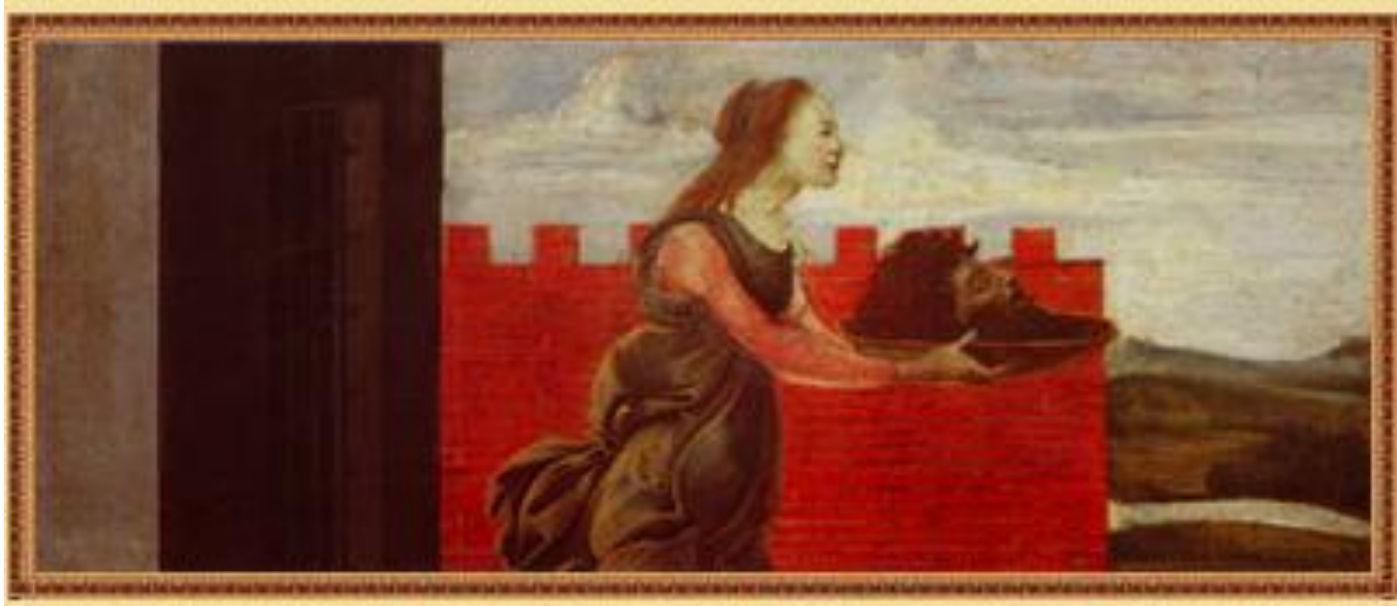

Salomé

Autor: Sandro Botticelli (1445 - 1510)

Ano da obra: 1488

\section{FIGURA 05}

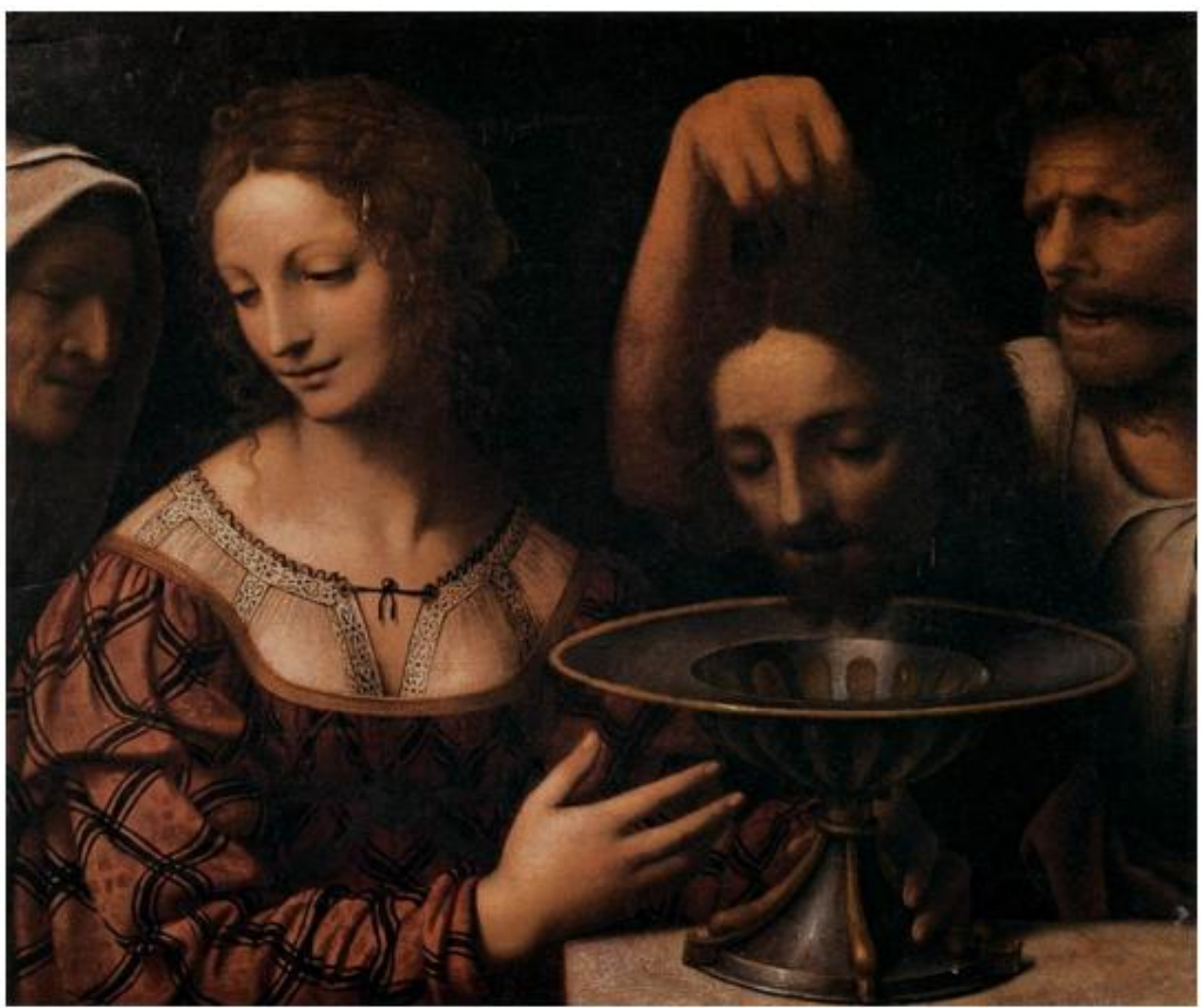

Salomé

Autor: Bernardino Luini (1480 - 1532)

Data da obra: Provavelmente entre 1527-31 
FIGURA 06

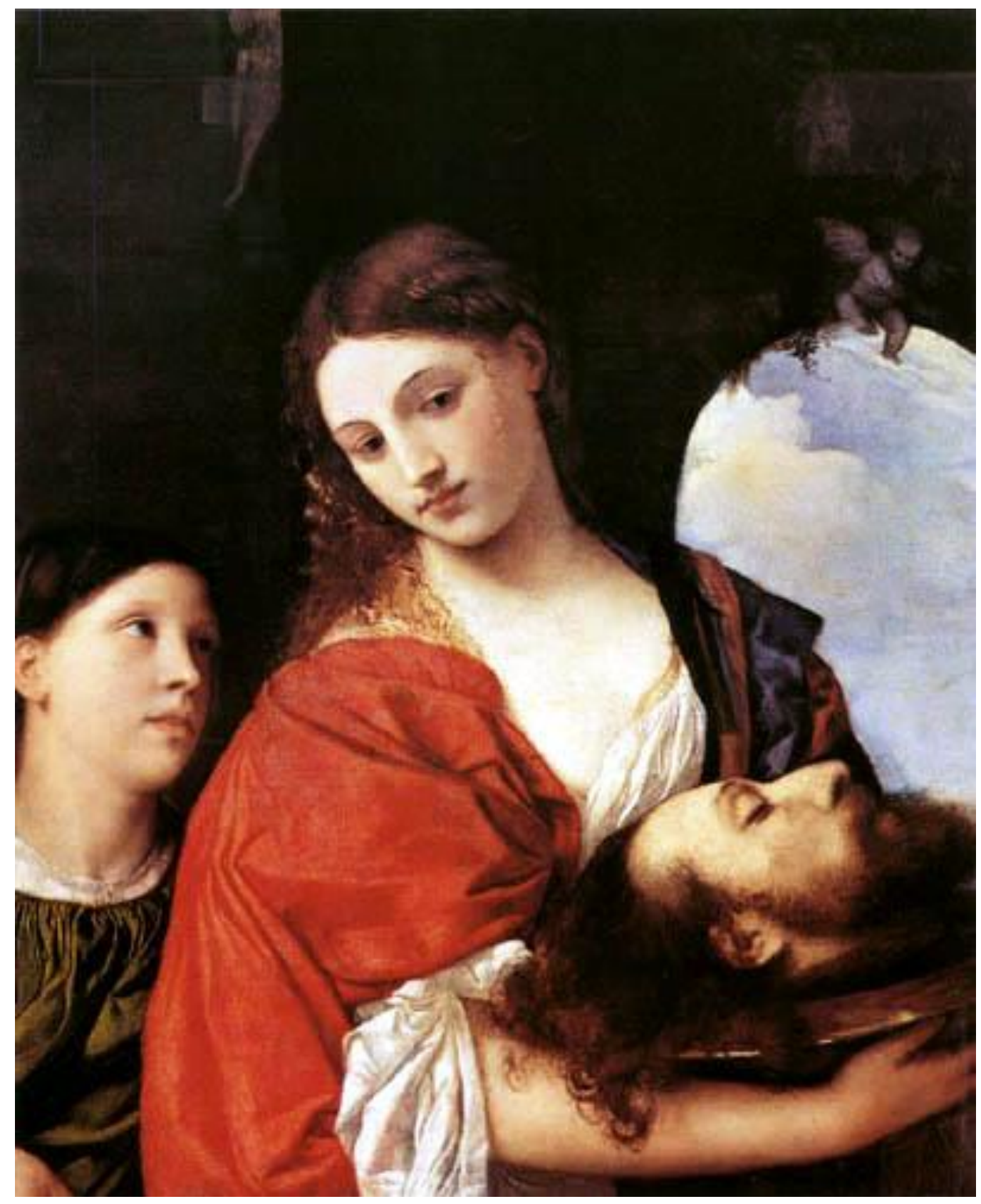

Salomé

Autor: Titian (Tiziano Vecellio) (1488 - 1576)

Ano da obra: 1515 
FIGURA 07

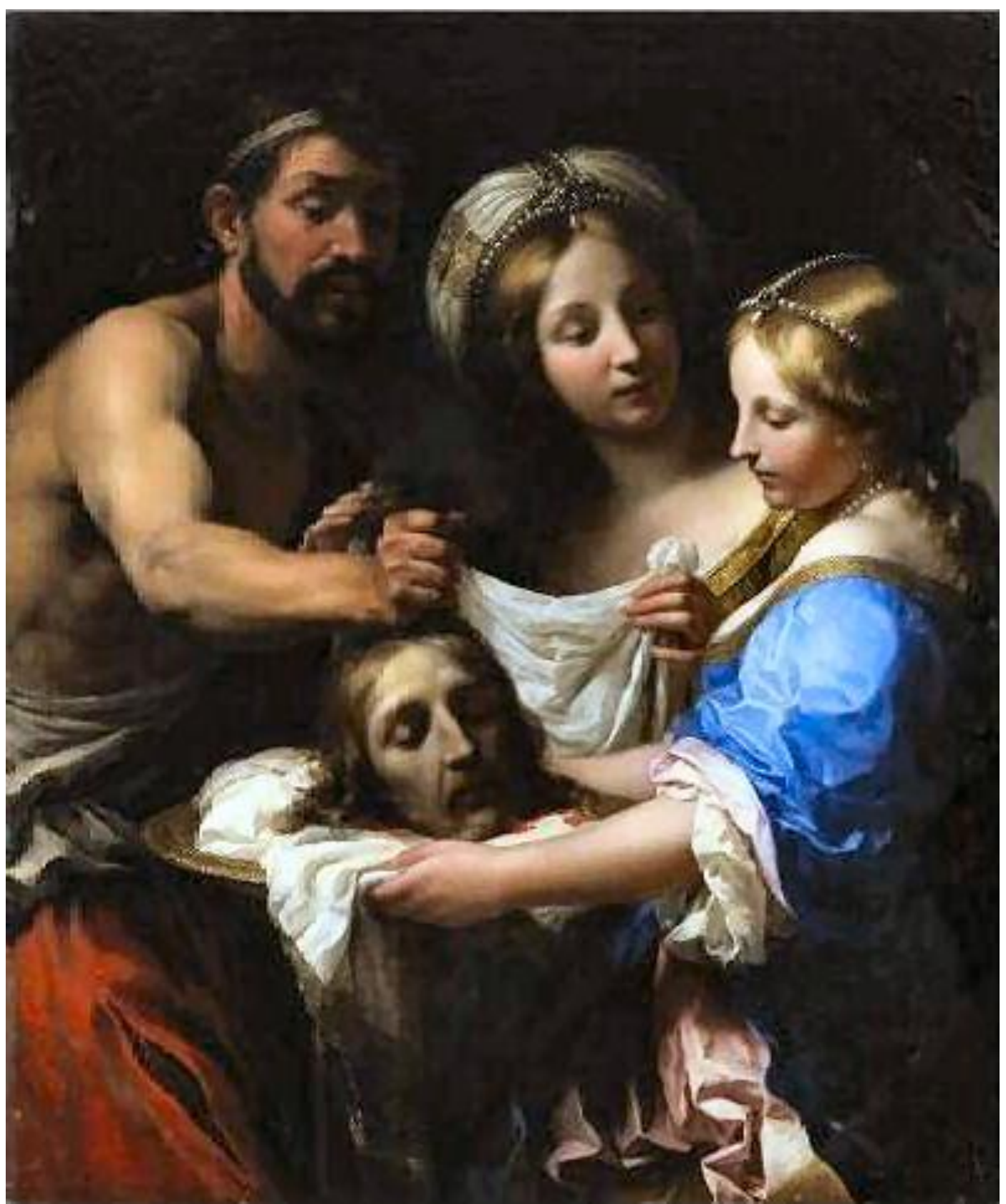

Salomé com a cabeça de João Batista

Autor: Onório Mariani (1627-1715)

Ano da obra: 1680 
FIGURA 08

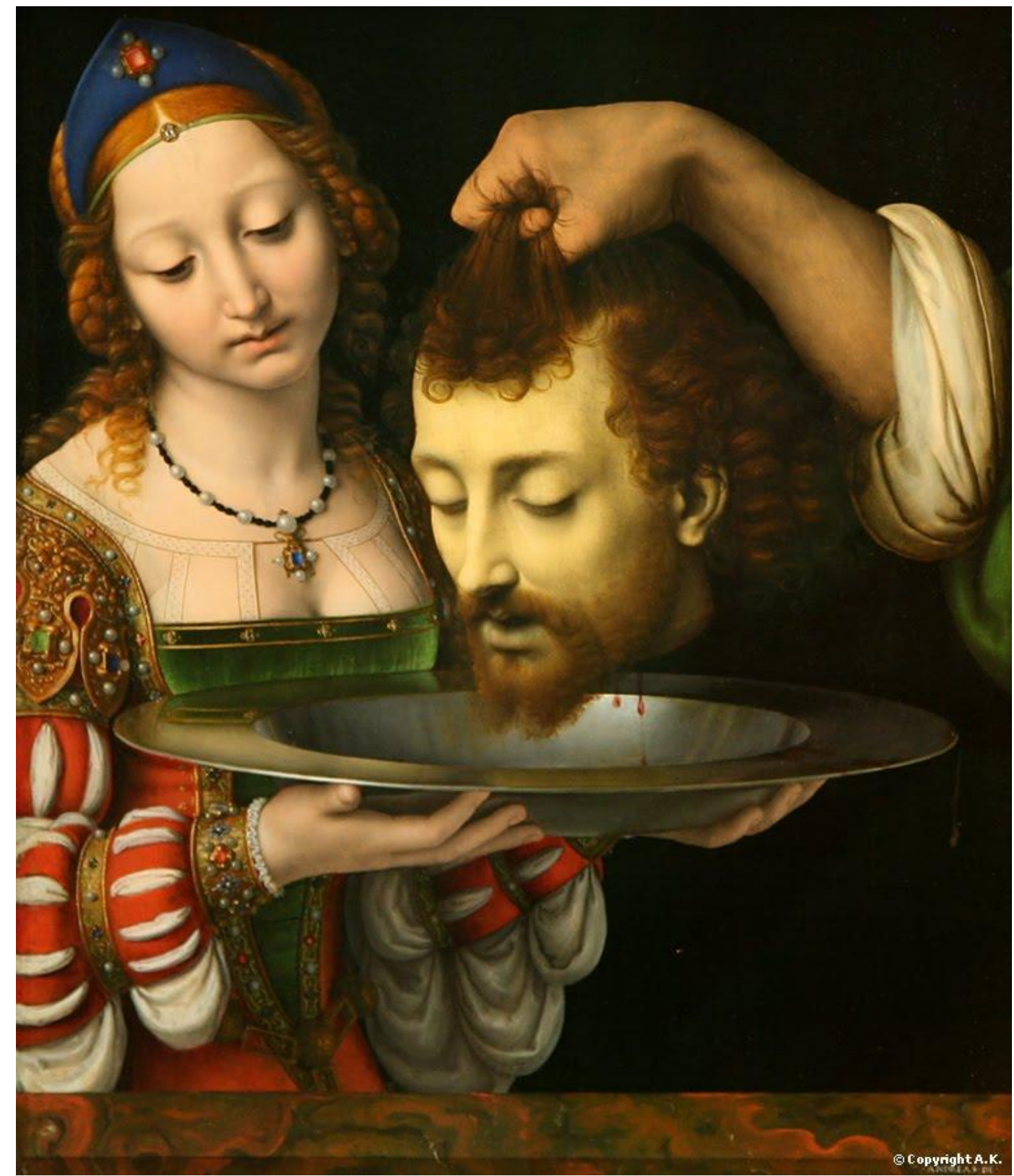

Salomé com a cabeça de João Batista

Autor: Andrea Solário (1460 - 1524)

Data da obra: entre 1506 e 1507 


\section{FIGURA 09}

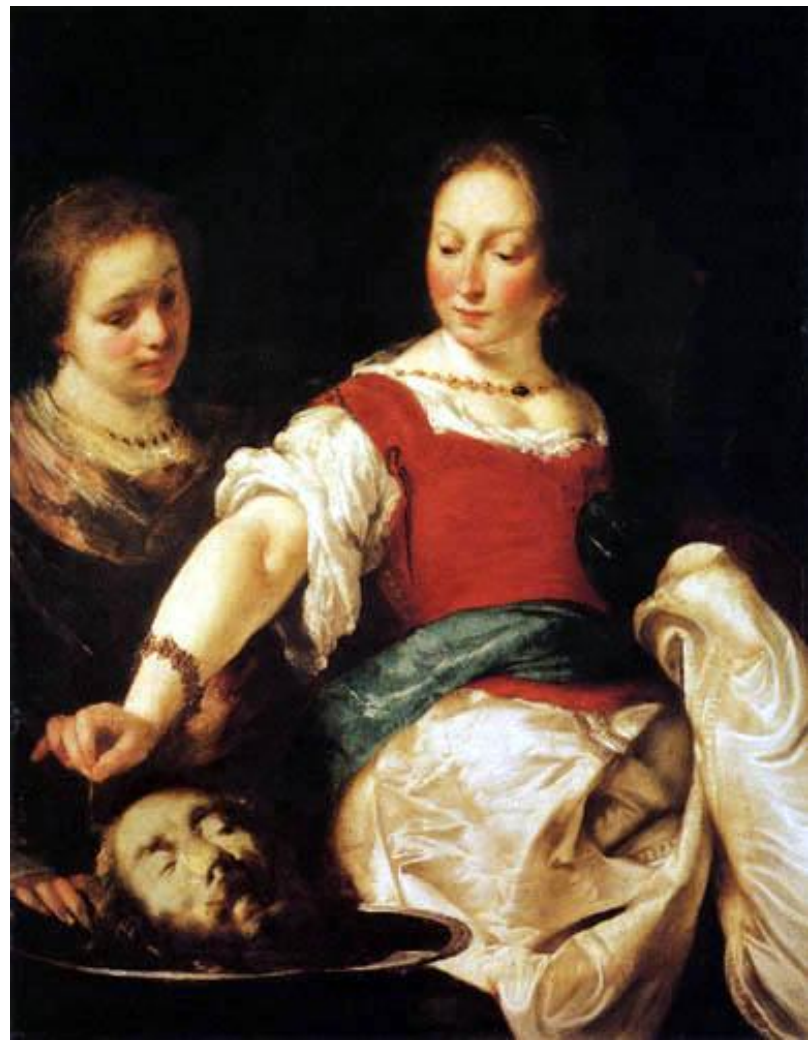

Salomé

Autor: Bernardo Strozzi (1581 - 1644)

Ano da obra: 1625

\section{FIGURA 10}

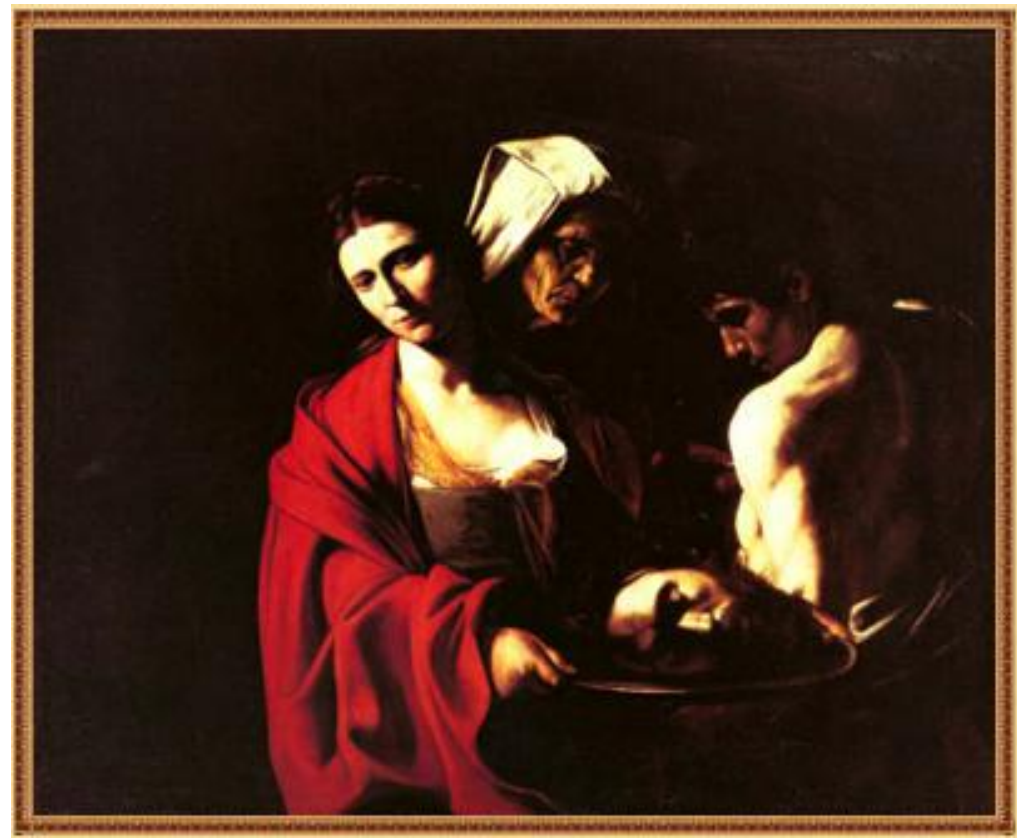

Salomé

Autor: Michelangelo Merisi de Caravaggio (1573 - 1610) Ano da obra: 1609 


\section{FIGURA 11}

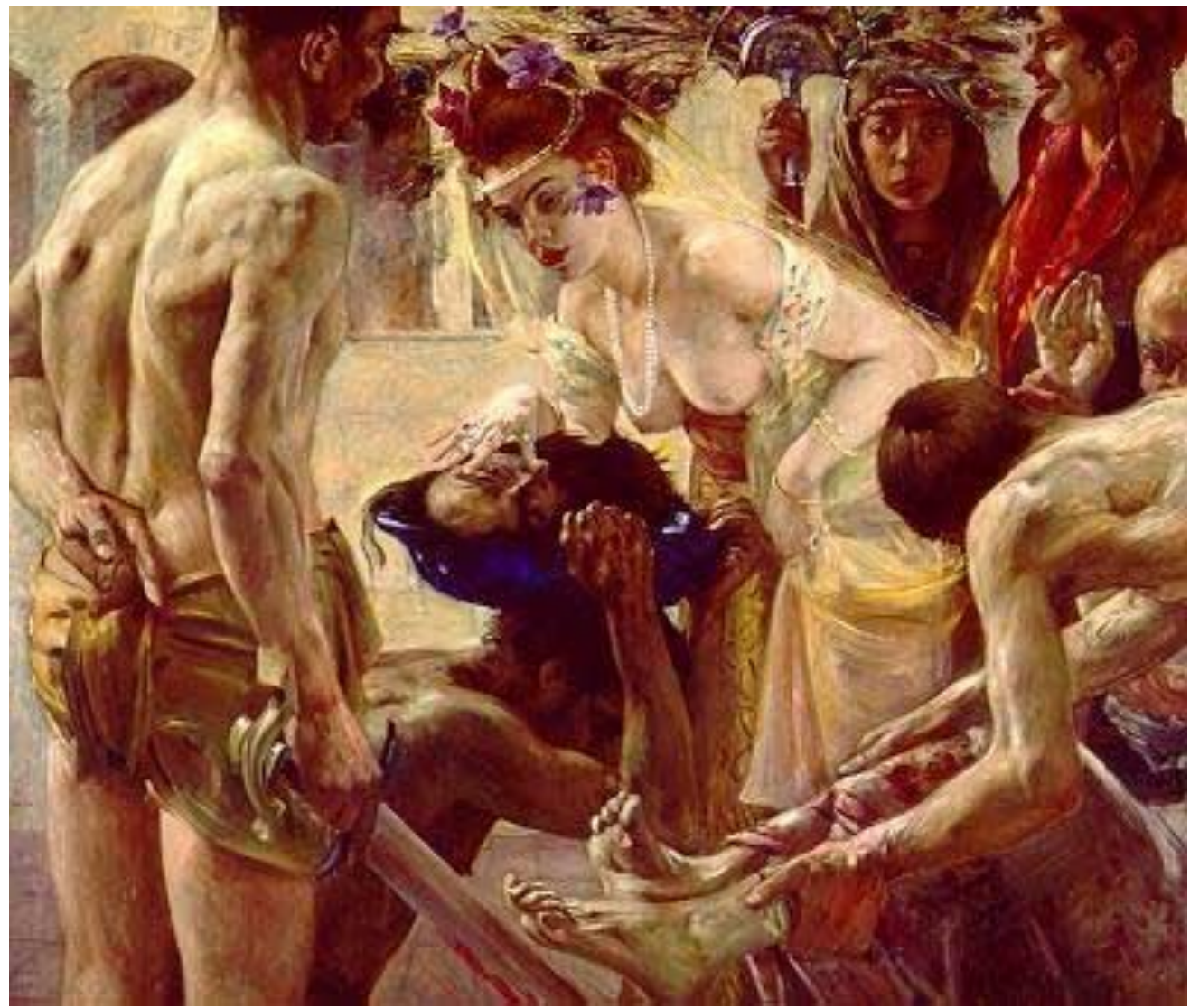

Salomé

Autor: Lovis Corinth (1858 - 1925)

Data da obra: 1900

\section{FIGURA 12}

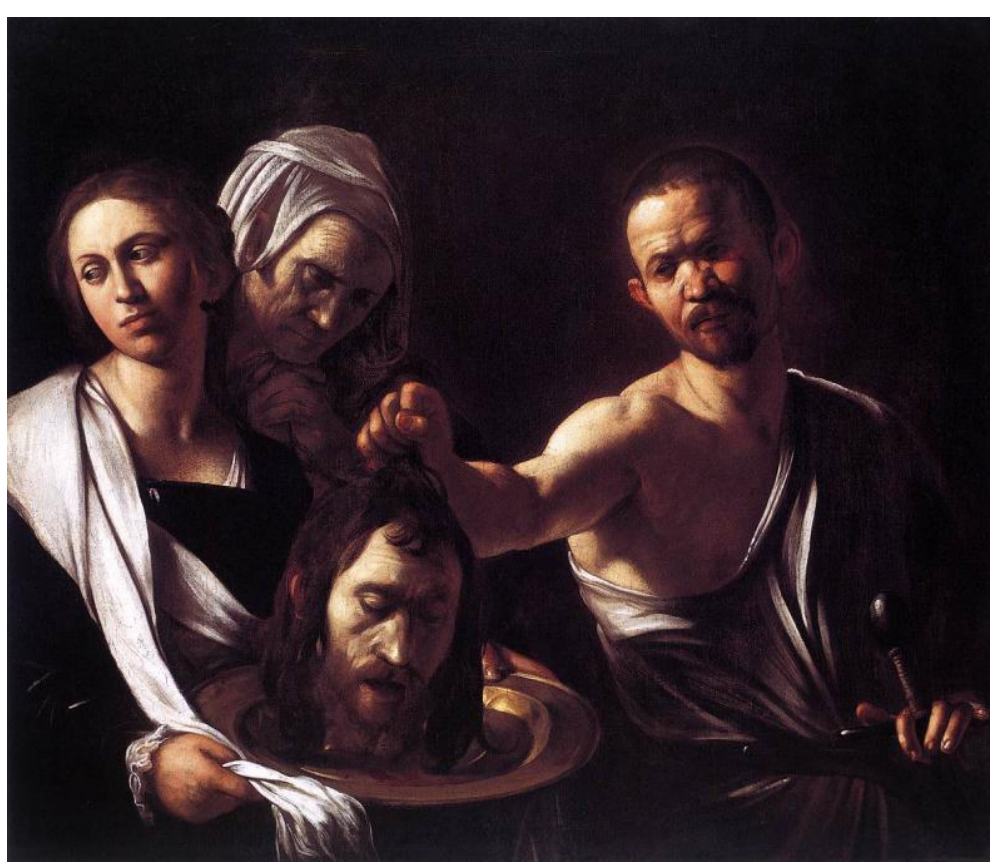

Salomé

Autor: Michelangelo Merisi da Caravaggio (1571 - 1610)

Data da obra: 1609 
FIGURA 13

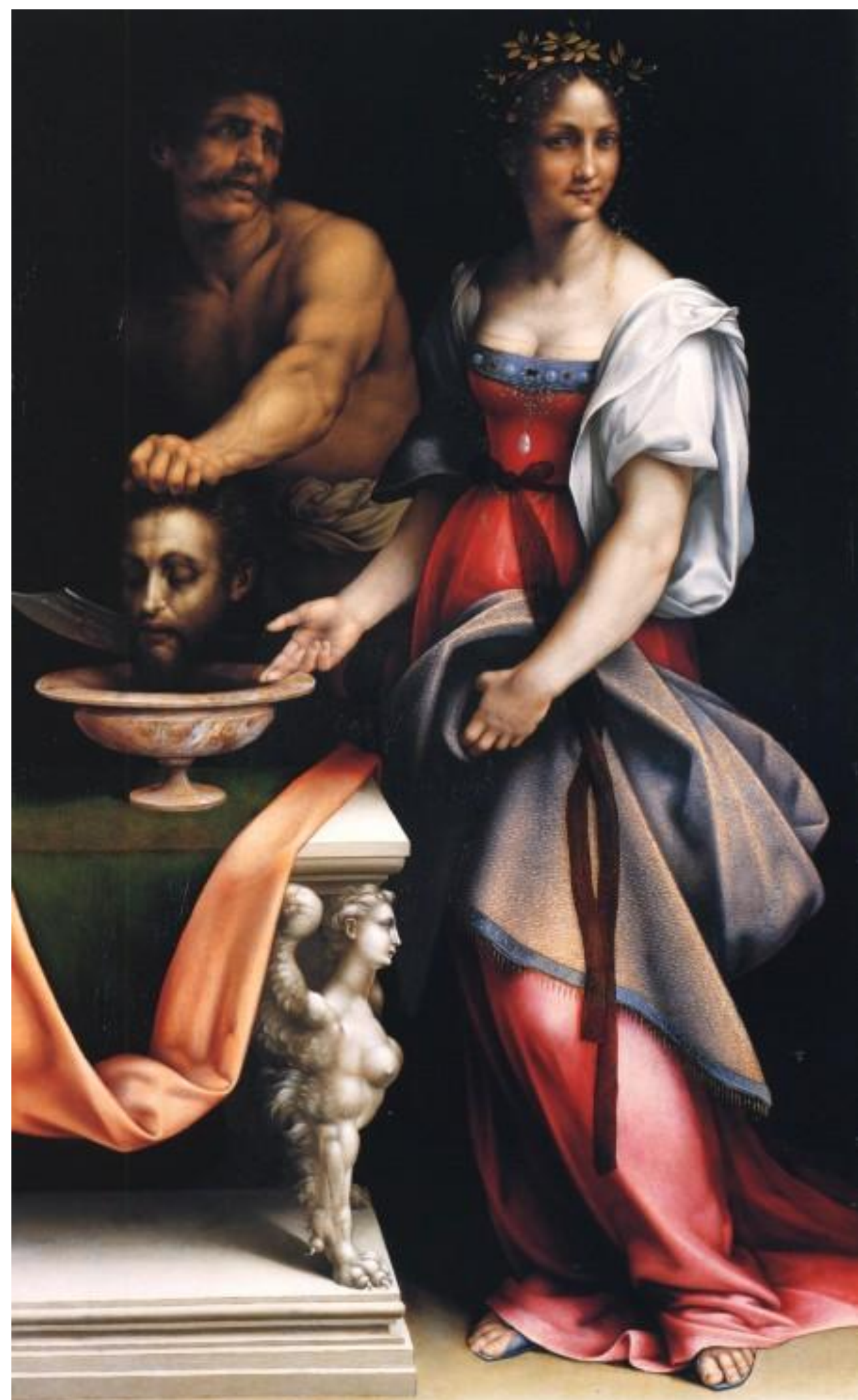

Salomé

Autor: Cesare da Cesto (1447 - 1523)

Data da obra: 1515 
FIGURA 14

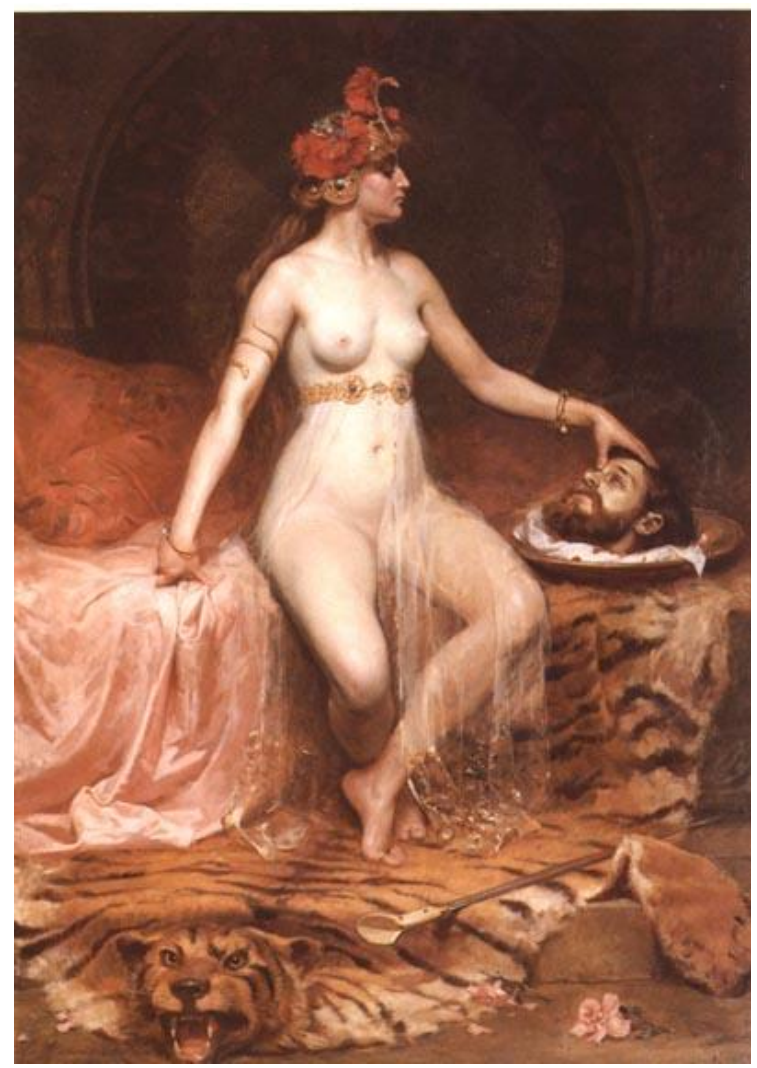

Salomé

Autor: Pierre Bonnaud's (1865 - 1930)

Data da obra: 1865

FIGURA 15

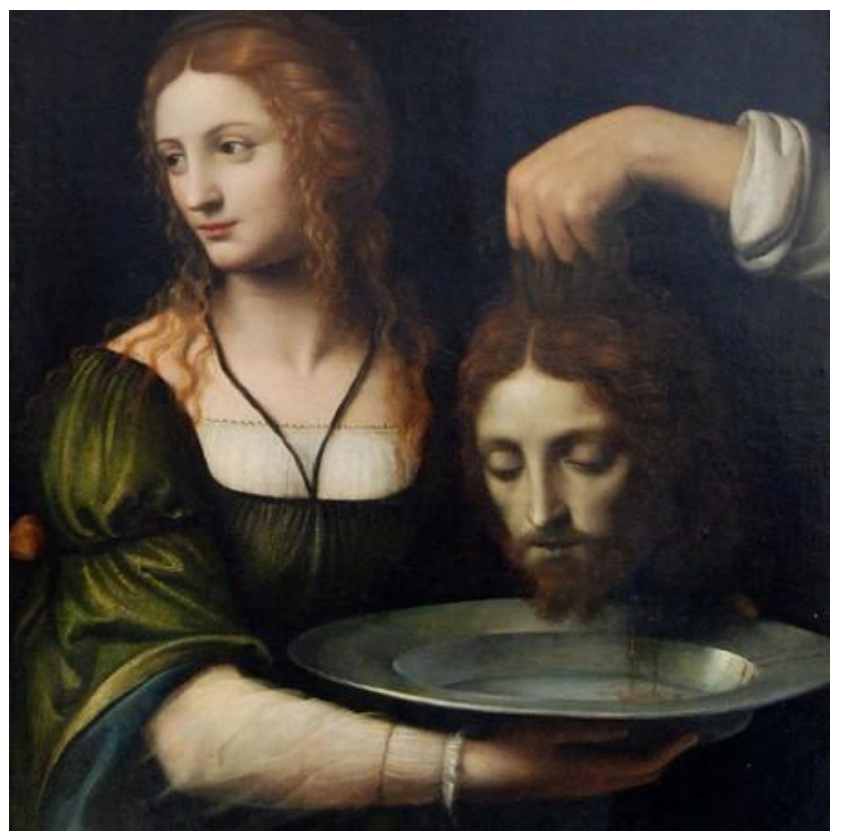

Salomé

Autor: Bernadino Luini (c.1480/82 - 1532)

Data da obra: 1527 
FIGURA 16

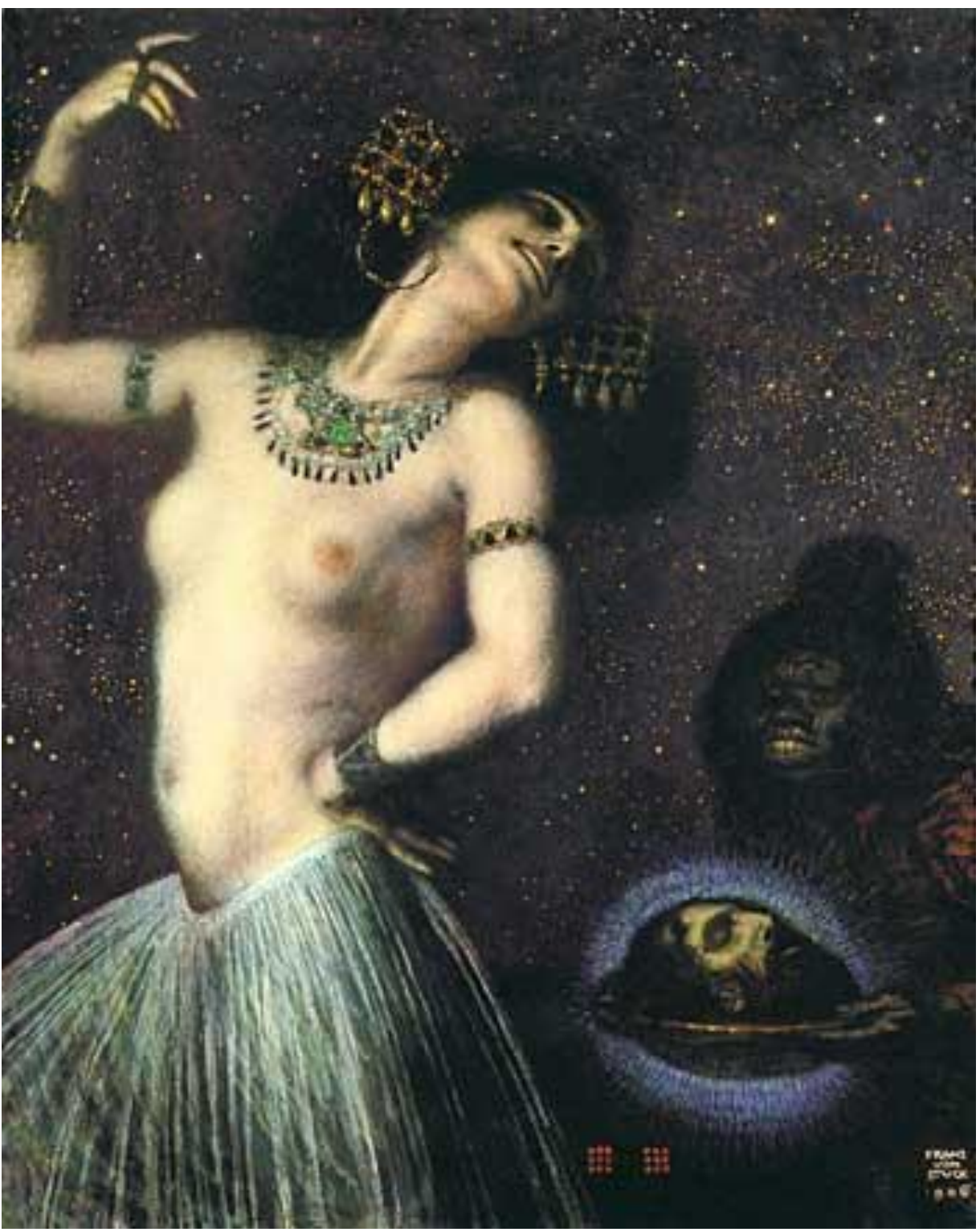

Salomé

Autor: Franz Von Stuck (1863-1928)

Data da obra: 1906 
FIGURA 17

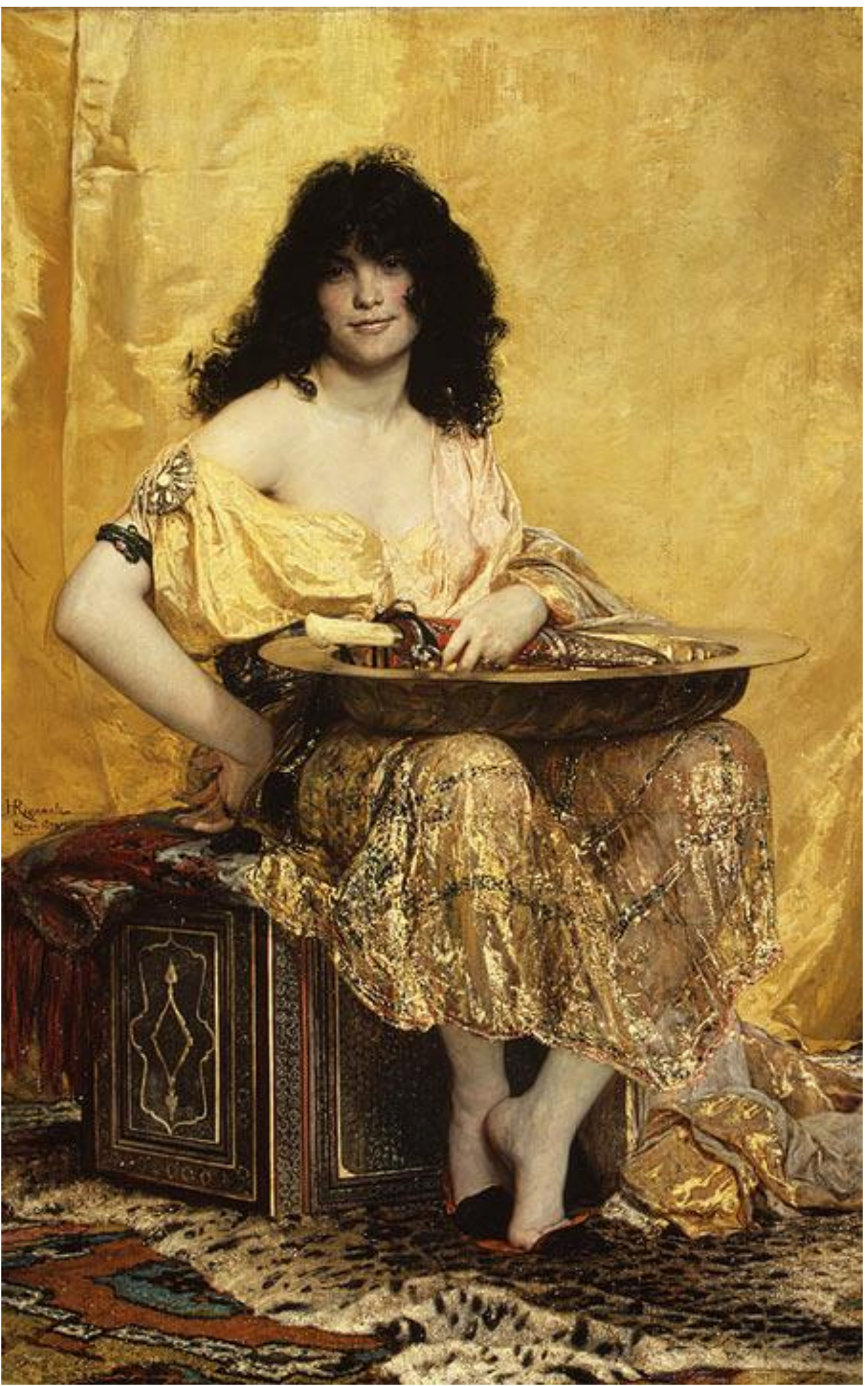

Salomé

Autor: Henri Regnault (1843 - 1871)

Data da obra: 1870 
FIGURA 18

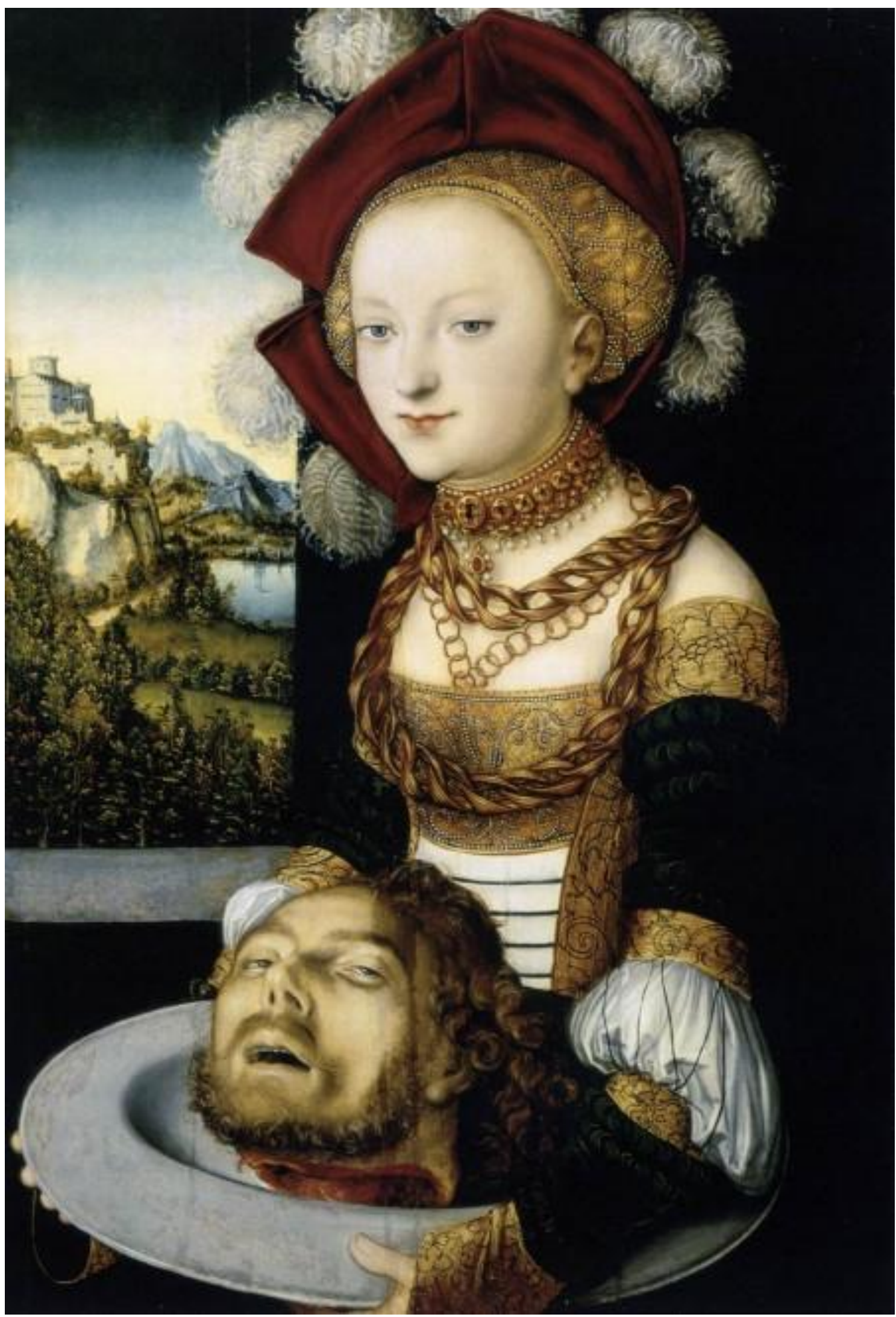

Salomé

Autor: Lucas Cranach the Elder (1472 - 1553)

Data da obra: 1530 
FIGURA 19

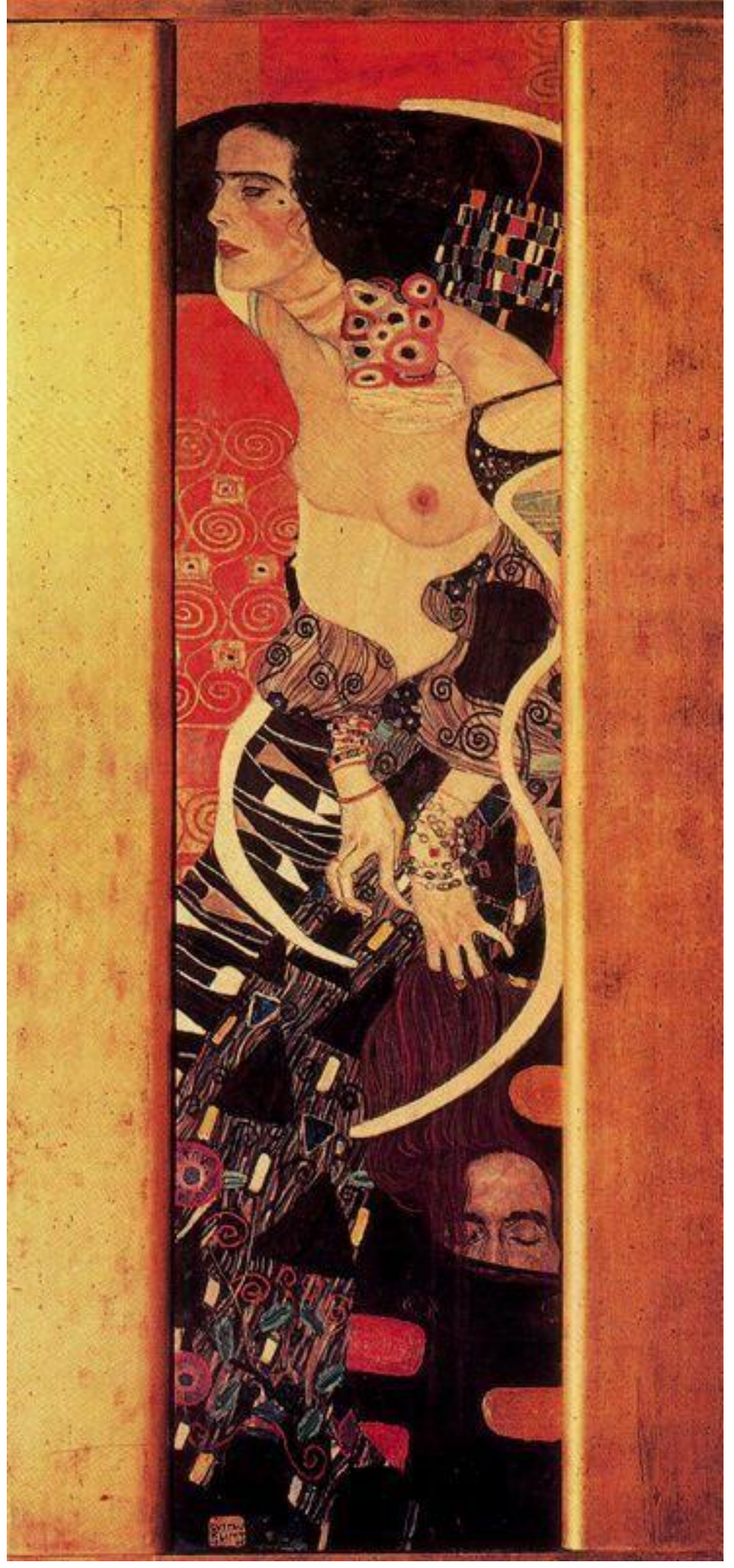

Salomé

Autor: Gustave Klimt (1862 - 1918)

Data da obra: 1909 
FIGURA 20

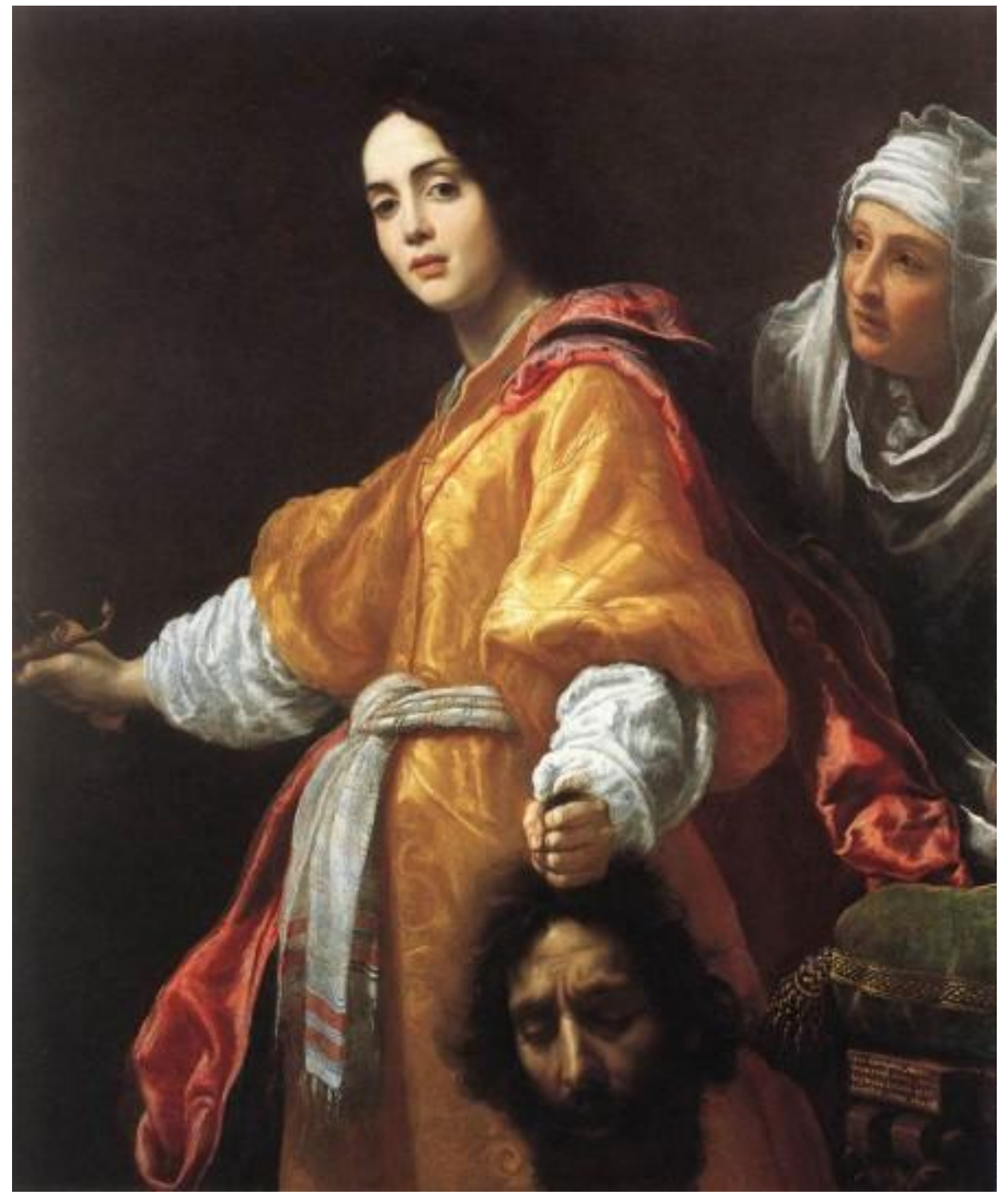

Salomé

Autor: Chistofano Allori (1577 - 1621)

Data da obra: 1613 


\section{FIGURA 21}

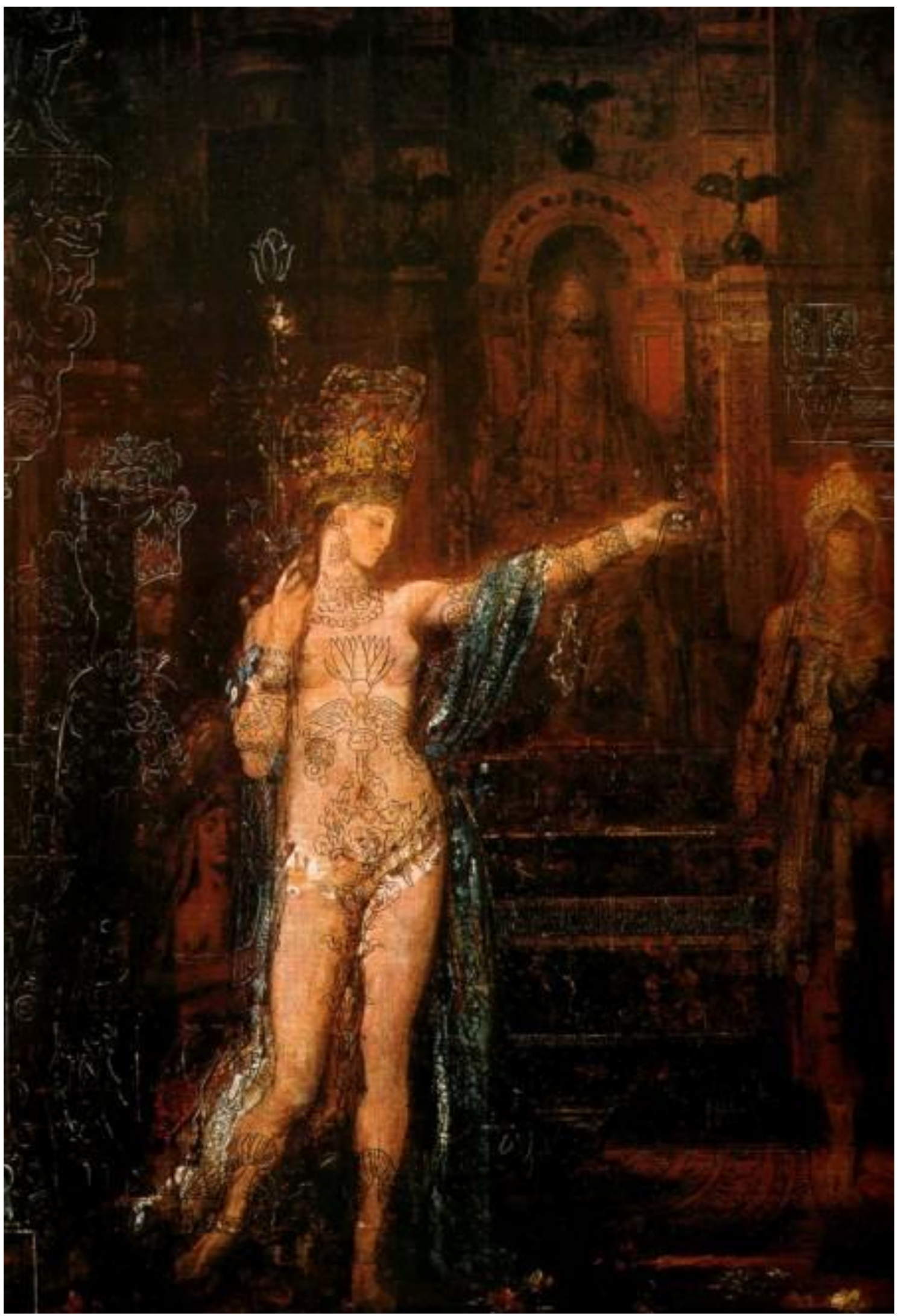

Salomé

Autor: Gustaves Moreau (1826 - 1898)

Data da obra: 1876 
FIGURA 22

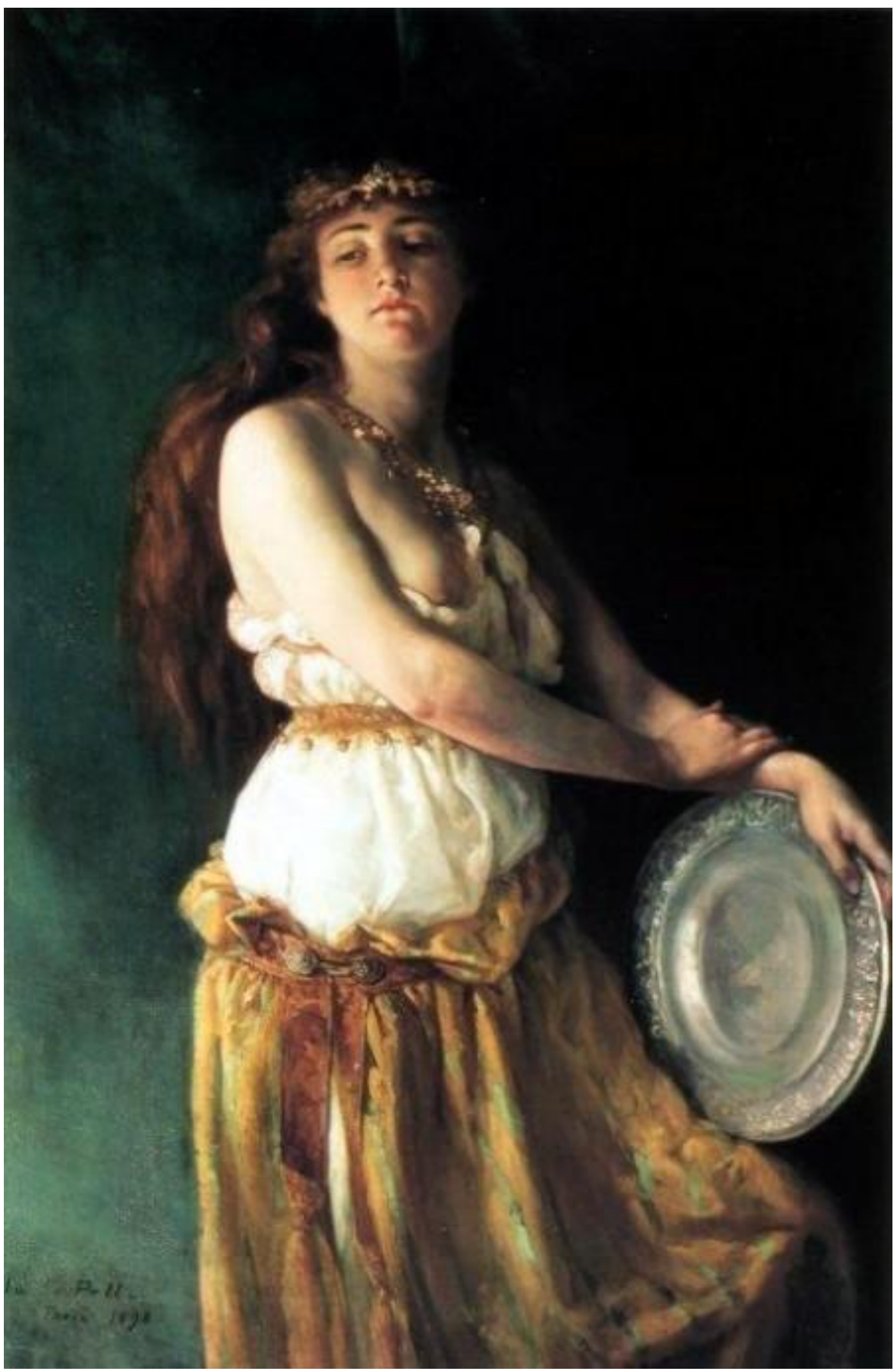

Salomé

Autor: Ella Ferris Pell (1846 -1922)

Data da obra: 1890 
FIGURA 23

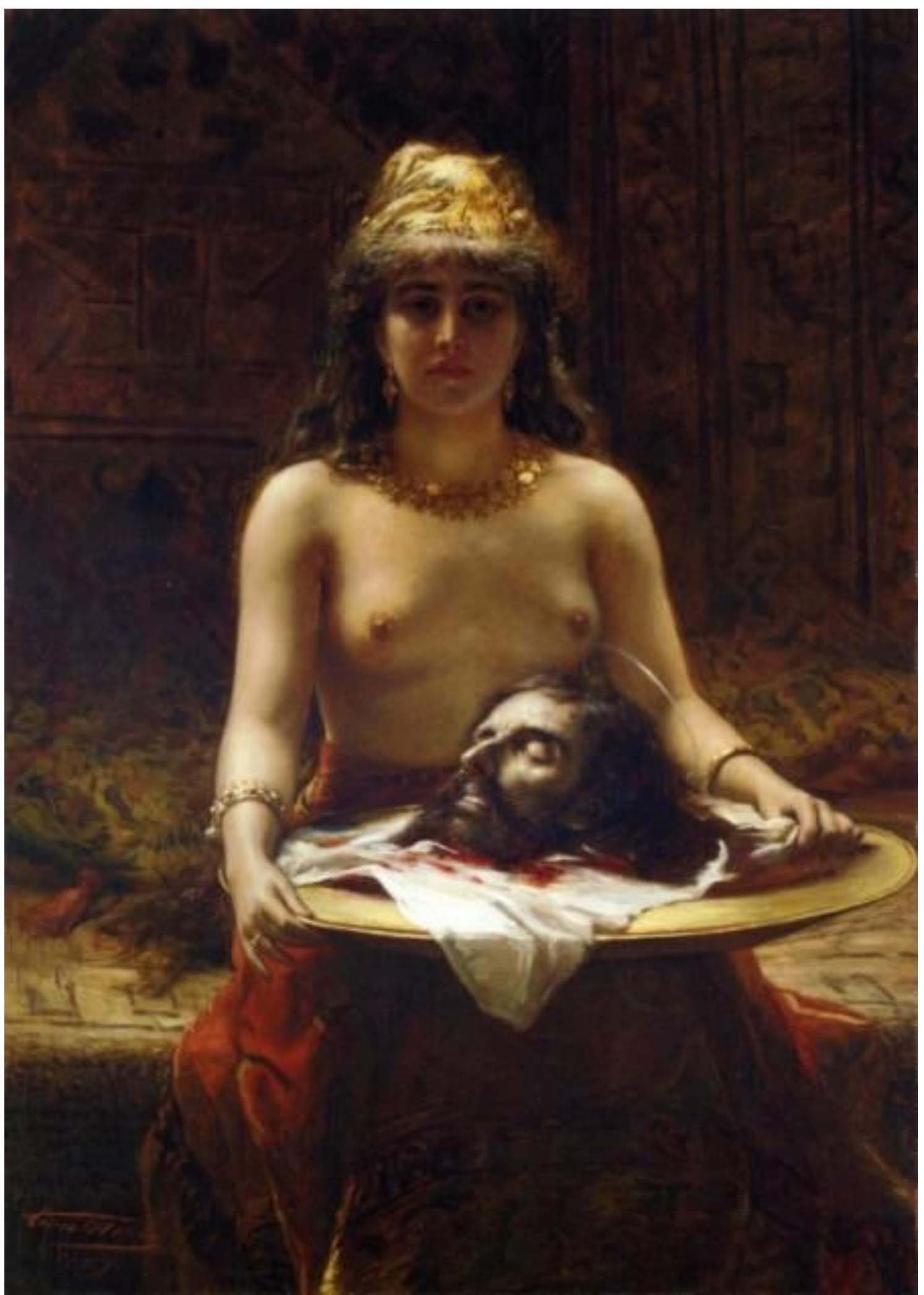

Salomé

Autor: Leon Herbo (1850 - 1907)

Data da obra: 1889 
FIGURA 24

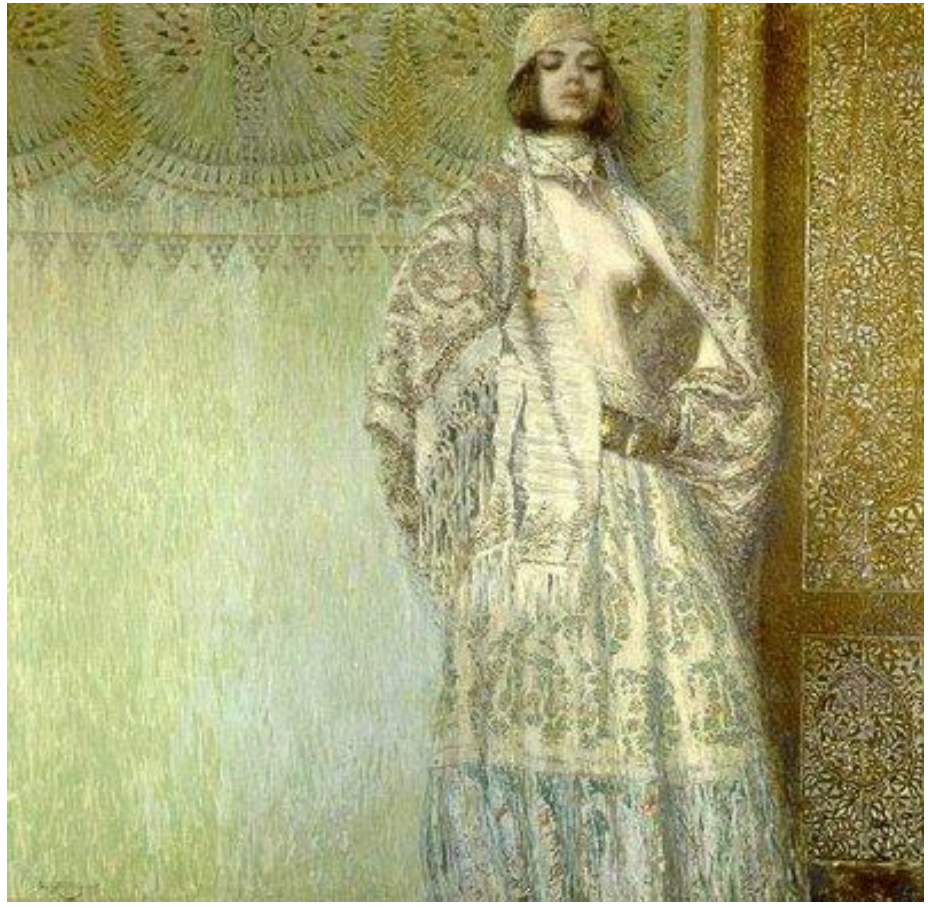

Salomé

Autor: Vardgas Surenyants (1860 - 1921)

Data da obra: 1907

FIGURA 25

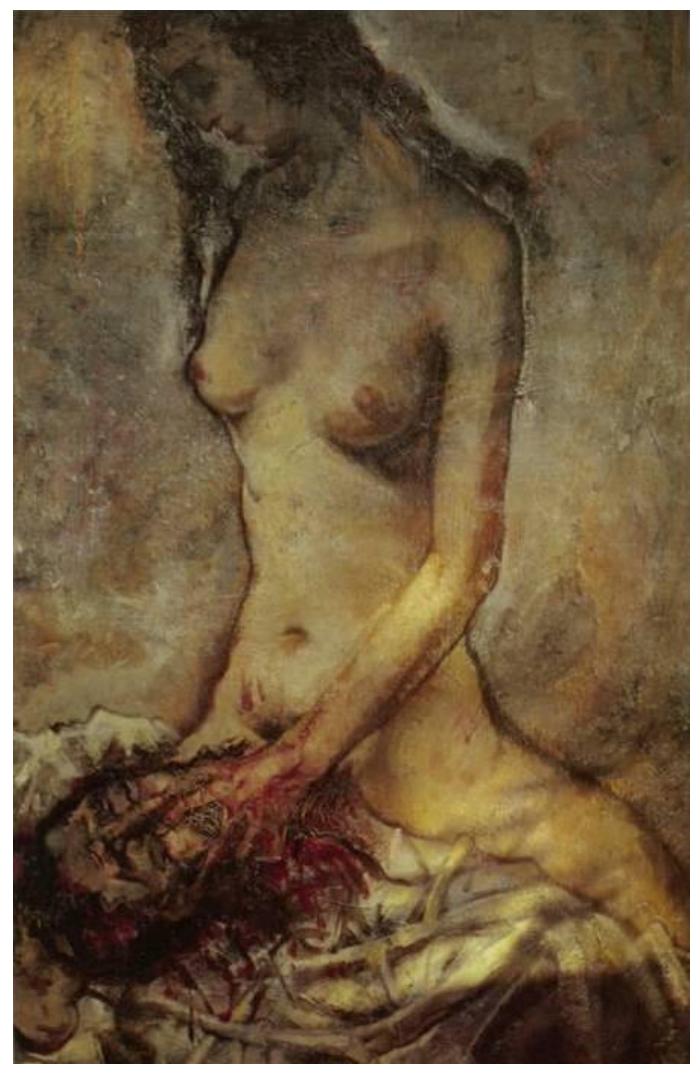

Salomé

Autor: Max Oppenheimer (1885 - 1954)

Data da obra: 1913 
FIGURA 26

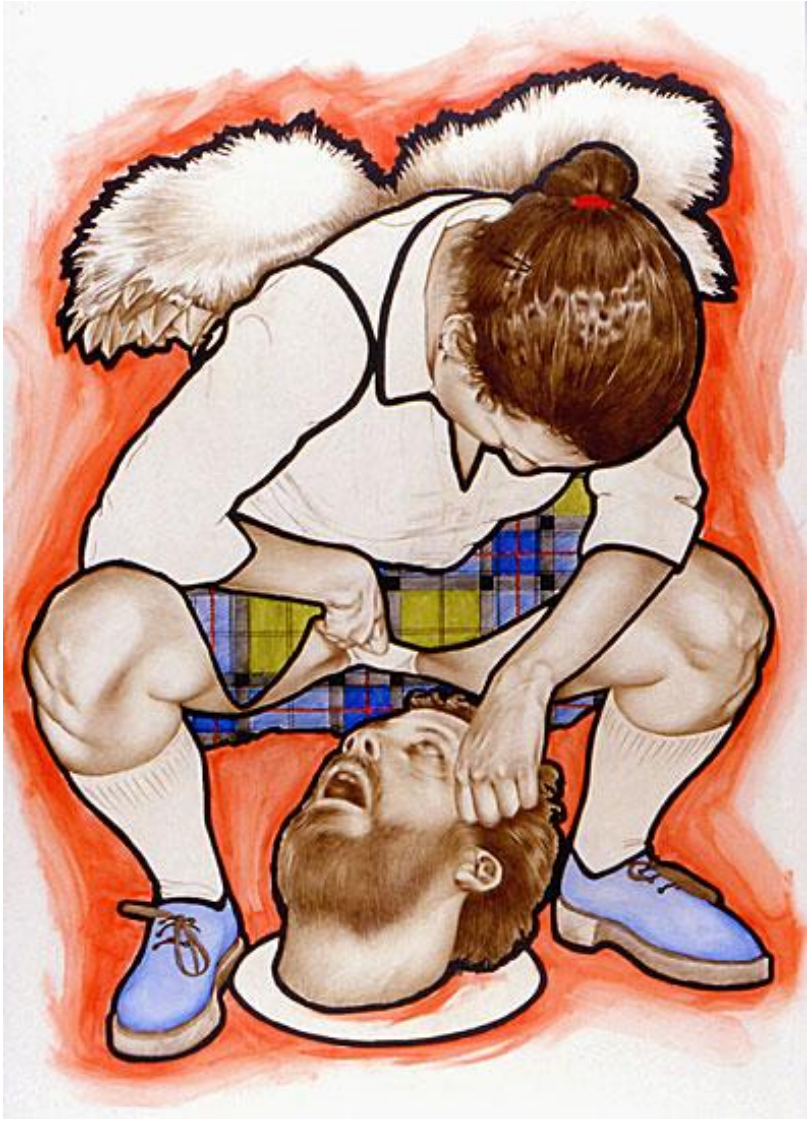

Salomé

Autor: Jennifer Linton (1968)

Data da obra: 2002

FIGURA 27

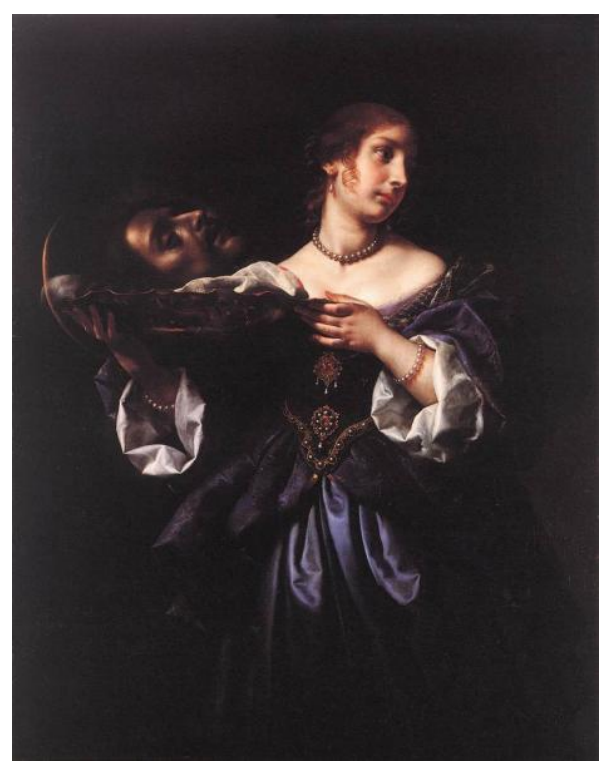

Salomé

Autor: Carlo Dolci (1616 - 1686)

Data da obra: 1665-1670 
FIGURA 28

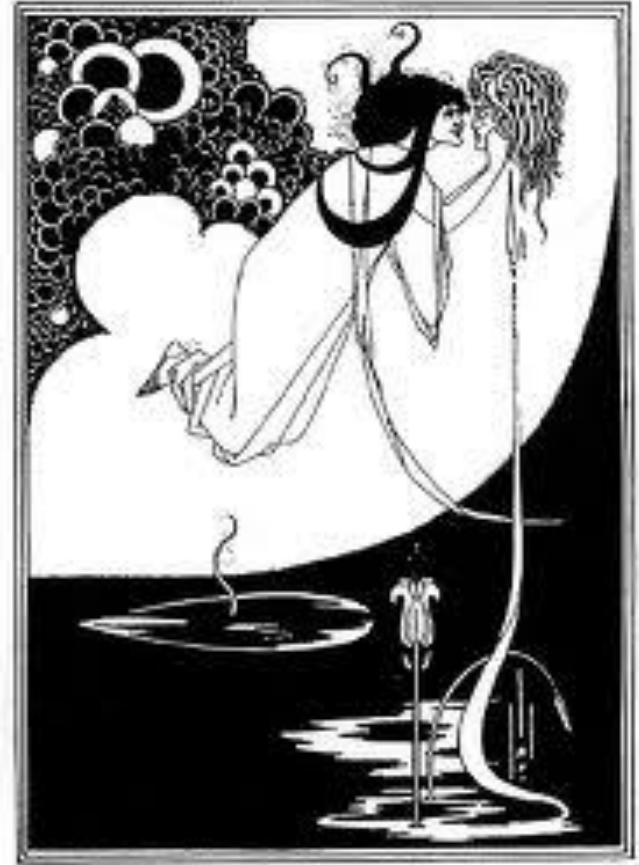

Salomé

Autor: Aubrey Beardsley (1872 - 1898)

Data da obra: 1896

\section{FIGURA 29}

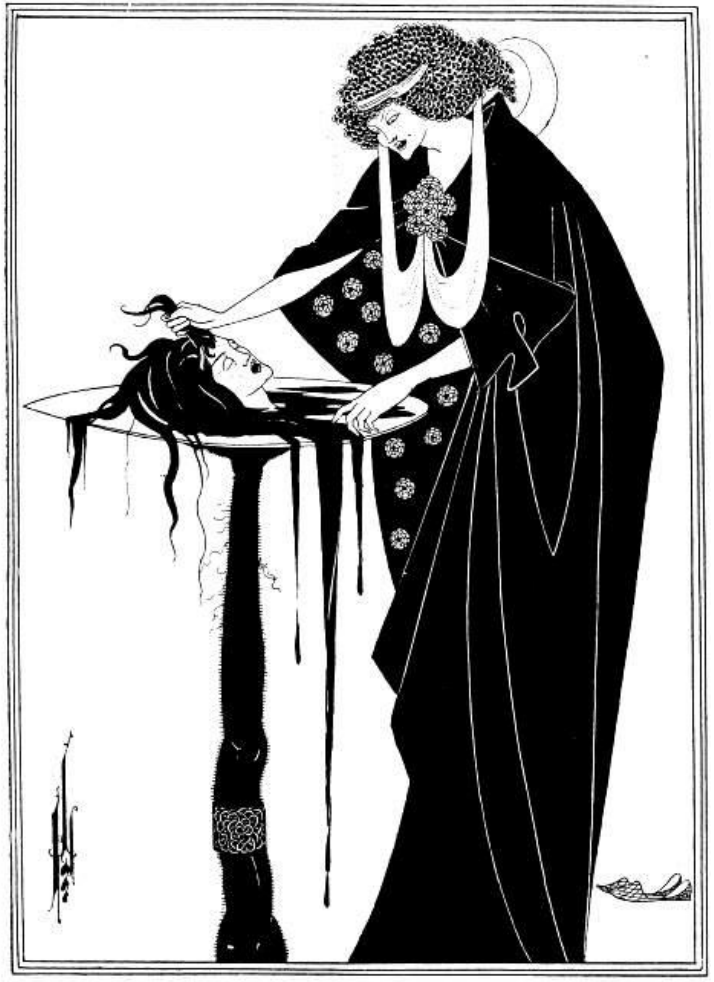

The Dancer's Reward

Autor: Aubrey Beardsley (1872 - 1898)

Data da obra: 1894 
FIGURA 30

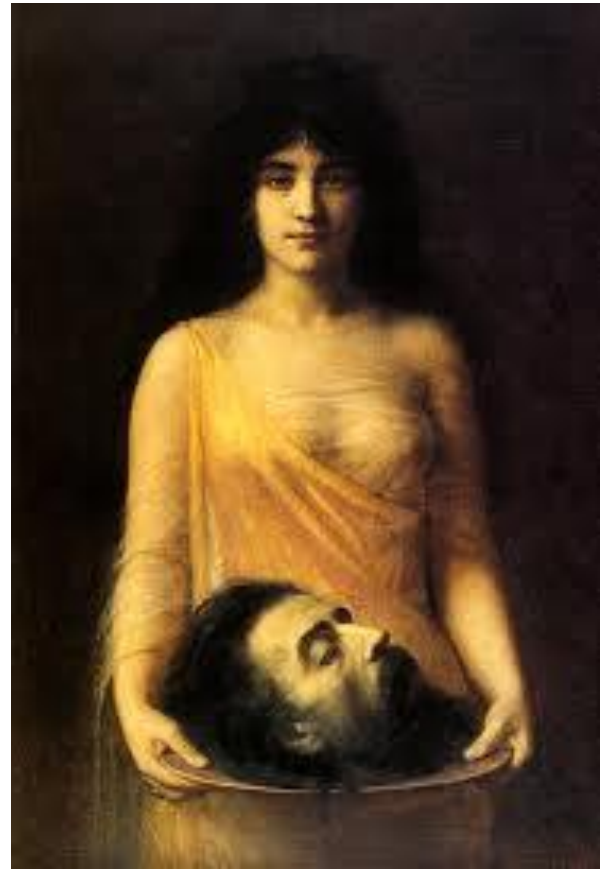

Salomé

Autor: Jean Benner's (1836 - 1909)

Data da obra: 1899

FIGURA 31

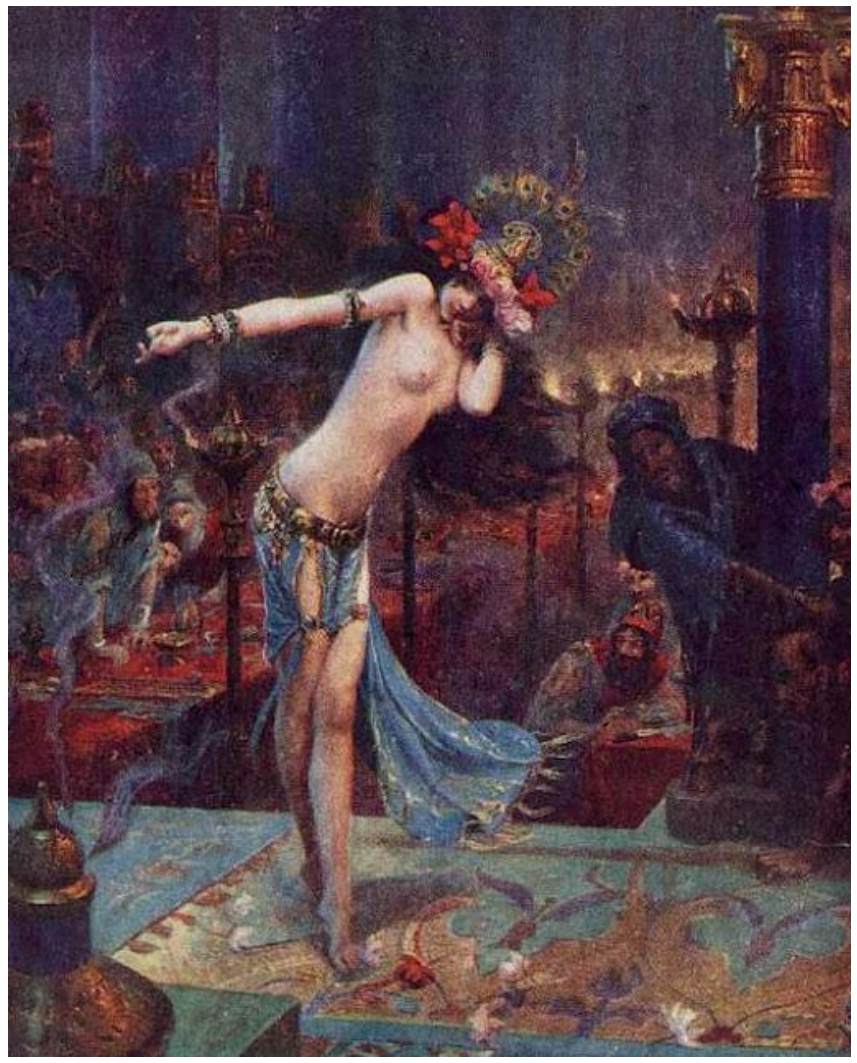

Salomé

Autor: Gaston Bussiére (1862 - 1928)

Data da obra: 1914 
FIGURA 32

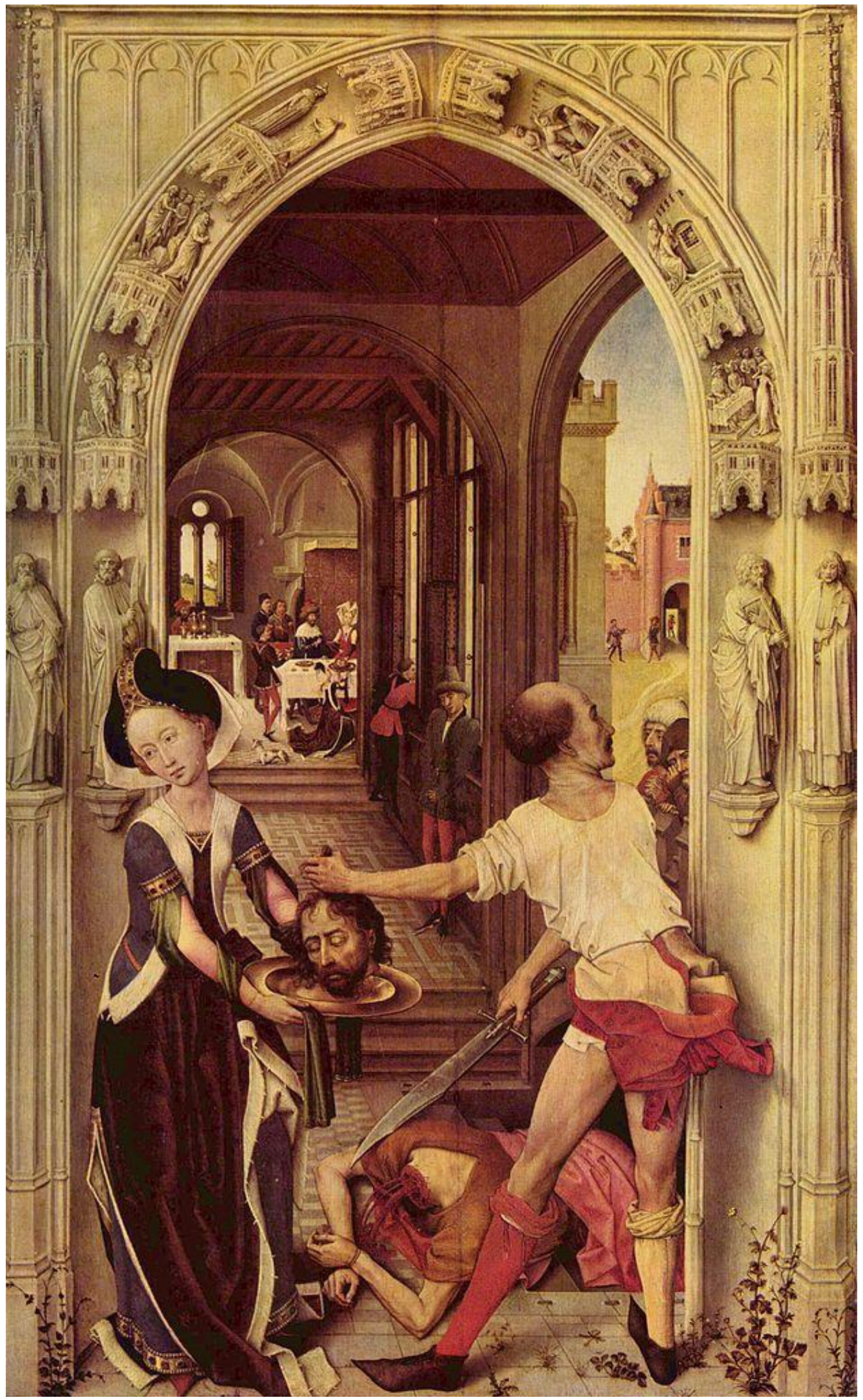

Salomé

Autor: Rogier van der Weyden (1400 - 1464)

Data da obra: 1450 
FIGURA 33

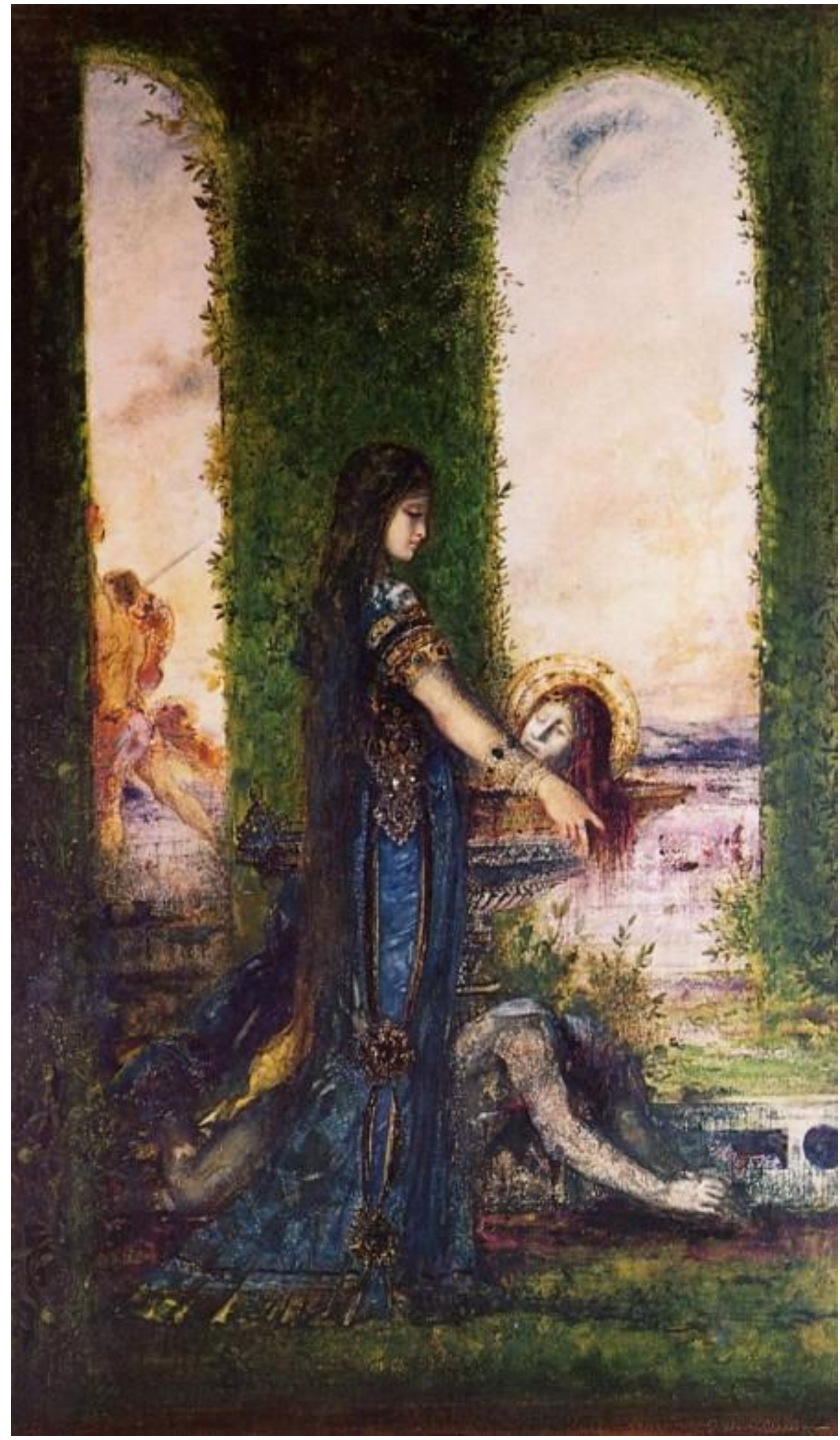

Salome in the Garden

Autor: Gustave Moreau (1826 - 1898)

Data da obra: 1878 
FIGURA 34

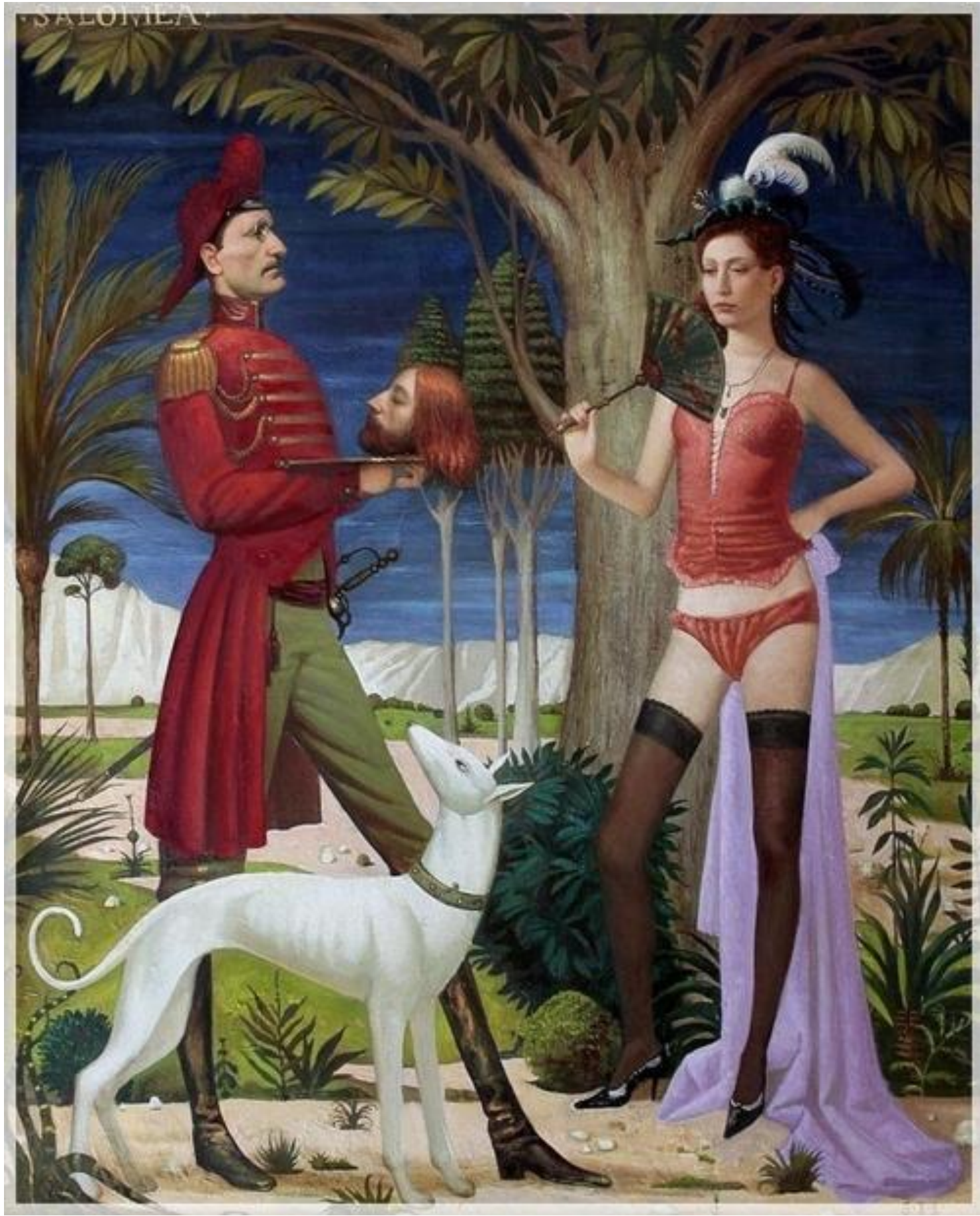

Salomé

Autor: Igor Samsonov (1963)

Data da obra: 2007 


\section{ENDEREÇOS ELETRÔNICOS DO ANEXO}

FIGURA 1:

http://dancadoventreportoalegre.blogspot.com.br/2011/06/lendas-e-mitos-da-

danca-do-sete-veus.html Acesso em 01/05/2012

FIGURA 2 :

http://abocalivre.wordpress.com/2011/04/27/a-sedutora-salome-e-o-reidrogado-caido-na-desgraca/ Acesso em 01/05/2012

FIGURA 3:

http://history-of-art.livejournal.com/253406.html Acesso em 01/05/2012

\section{FIGURA 4:}

http://www.reproarte.com/cuadro/Sandro Botticelli/Salomé+con+la+cabeza+del +Bautista/1156.html Acesso em 01/05/2012

FIGURA 5:

http://fr.wahooart.com/a55a04/w.nsf/Opra/BRUE-8BWNHK Acesso em 01/05/2012

FIGURA 6:

http://www.reproarte.com/picture/ Tizian+ Tiziano+Vecellio /Salomé/11206.ht ml Acesso em 01/05/2012

\section{FIGURA 7:}

http://en.wikipedia.org/wiki/File:Onorio Marinari Salomé con la cabeza del B autista 1680 Minneapolis MA.jpg Acesso em 01/05/2012

FIGURA 8:

http://silvinhoz.blogspot.com.br/2010/06/prologo-para-salome.html Acesso em 01/05/2012

FIGURA 9:

http://www.reproarte.com/cuadro/Bernardo Strozzi/Salomé+con+la+cabeza+de I+Bautista/10759.html Acesso em 01/05/2012

FIGURA 10:

http://www.reproarte.com/cuadro/Michelangelo+Merisi+da Caravaggio/Salomé +con+la+cabeza+del+Bautista/1968.html Acesso em 01/05/2012

FIGURA 11:

http://artcontrarian.blogspot.com.br/2012/01/molti-ritratti-salome.html Acesso em 05/05/2012 
FIGURA 12:

http://artehistoriadaarte.blogspot.com.br/2010/09/salome-com-cabeca-de-joaobatista.html Acesso em 08/05/2012

FIGURA 13:

http://books.elliottback.com/salome-in-art-painting/ Acesso em 20/05/2012

FIGURA 14:

http://artcontrarian.blogspot.com.br/2012/01/molti-ritratti-salome.html Acesso em 05/05/2012

FIGURA 15:

http://books.elliottback.com/salome-in-art-painting/ Acesso em 24/05/2012

FIGURA 16:

http://www.illusionsgallery.com/salome.html Acesso em 05/05/2012

FIGURA 17:

http://www.metmuseum.org/toah/works-of-art/16.95 Acesso em 01/05/2012

FIGURA 18:

http://books.elliottback.com/salome-in-art-painting/ Acesso em 24/05/2012

FIGURA 19:

http://books.elliottback.com/salome-in-art-painting/ Acesso em 24/05/2012

FIGURA 20:

http://books.elliottback.com/salome-in-art-painting/ Acesso em 24/05/2012

FIGURA 21:

http://books.elliottback.com/salome-in-art-painting/ Acesso em 24/05/2012

FIGURA 22:

http://books.elliottback.com/salome-in-art-painting/ Acesso em 24/05/2012

FIGURA 23:

http://books.elliottback.com/salome-in-art-painting/ Acesso em 24/05/2012

FIGURA 24:

http://books.elliottback.com/salome-in-art-painting/ Acesso em 24/05/2012 
FIGURA 25:

http://whosthatgirl-searchme.blogspot.com.br/2011/12/salome.html Acesso em $24 / 05 / 2012$

FIGURA 26:

http://barnyardblunder.blogspot.com.br/2011/09/salome.html Acesso em $24 / 05 / 2012$

FIGURA 27:

http://www.friendsofart.net/en/art/carlo-dolci/salome-with-the-head-of-st-johnthe-baptist Acesso em 24/05/2012

FIGURA 28:

http://historicalpassages.blogspot.com.br/2011/06/black-book.html Acesso em $24 / 05 / 2012$

FIGURA 29:

http://www.victorianweb.org/art/illustration/beardsley/33.html $\quad$ Acesso em $24 / 05 / 2012$

FIGURA 30:

http://kebekmac.blogspot.com.br/2012 0401 archive.html Acesso em 24/05/2012

FIGURA 31:

http://whosthatgirl-searchme.blogspot.com.br/2011/12/salome.html Acesso em $24 / 05 / 2012$

FIGURA 32:

http://whosthatgirl-searchme.blogspot.com.br/2011/12/salome.html Acesso em $24 / 05 / 2012$

FIGURA 33:

http://books.elliottback.com/salome-in-art-painting/ Acesso em 24/05/2012

FIGURA 34:

http://ymutate.tumblr.com/post/18969579581/igor-samsonov-russian-paintersalome-found Acesso em 24/05/2012 